\title{
A HISTORY OF SAME-SEX MARRIAGE
}

\author{
William N. Eskridge, Jr.*
}

\section{INTRODUCTION}

W E'WHA was a key cultural and political leader in the Zuni community in the late nineteenth century, at one point serving as an emissary from that southwestern Native American nation to Washington, D.C. ${ }^{1}$ He was the strongest, wisest, and most esteemed member of his community. And he was a berdache, a inale who dressed in female garb. Such men were revered in Zuni circles for their supposed connection to the supernatural, the most gifted of them called lhamana, spiritual leader. We'wha was the most celebrated Zuni lhamana of the nineteenth century. He was niarried to a man.

Ifeyinwa Olinke lived in the nineteenth century as well. ${ }^{2}$ She was a wealthy woman of the Igbo tribe, situated in what is now Eastern Nigeria. She was an industrious woman in a comnunity where most of the entrepreneurial opportunities were seized by women, wlio thereby came to control niuch of the Igbo tribe's wealth. Ifeyinwa socially overshadowed her less prosperous male husband. As a sign of

* Professor of Law, Georgetown University Law Center; Visiting Professor of Law, New York University School of Law.

This Article originated with work I did in connection with my ongoing representation of a gay couple suing the District of Columbia for a marriage license. Dean v. District of Columbia, No. CA 90-13892 (D.C. Super. Ct. Dec. 30, 1991), appeal docketed, No. 92-737 (D.C. Ct. App. June 2, 1992). Critically useful primary source leads were provided by Professors William Leap and Geoffrey Burkhart, both anthropologists at American University, and by Father Alexei Michalenko, the Chaplain at the Georgetown University Law Center.

I received very helpful comments on earlier drafts of this Article from Marc Arkin, Yair Chamudot, Sylvia Law, Bill Nelson, Mitt Regan, David Richards, and numerous participants at presentations of this Article to the Sexual Orientation and the Law Reading Group of the Gay and Lesbian Attorneys of Washington, D.C: (GAYLAW), the student-sponsored Frontiers of Legal Thought Conference at the Duke Law School, the Georgetown University Law Center, the Fordham University School of Law, the New York University School of Law, and the Symposium on Sexual Orientation and the Law sponsored by the Virginia Law Review.

1 For an account of We'wha's life, see Will Roscoe, The Zuni Man-Woman 29-52 (1991).

2 For a description of Ifeyinwa's life, see Ifi Amadiume, Male Daughters, Female Husbands: Gender and Sex in an African Society 48-49 (1987). 
her prosperity and social standing, Ifeyinwa herself became a female husband to other women. Her epithet "Olinke" referred to the fact that she had nine wives.

Sergius and Bacchus were Roman soldiers who hived im the fourth century. ${ }^{3}$ They were male lovers. Yet it was for their Christian faith that they were persecuted by the Romans. Ultimately, Bacchus was tortured to death by the intolerant Romans. According to Christian tradition, Sergius' faith faltered with the death of his lover, only to return when Bacchus appeared to him in a vision and implored, "Your reward will be me," meaning that the couple would be reunited im heaven should Sergius maintain his faith. Sergius kept faith and, like his mate, died a martyr. During the Middle Ages, the relationship of Sergius and Bacchus was considered an exemplar of companionate marriage, or marriage based upon agapic love and mutual respect.

The stories of We'wha, Ifeyinwa Olinke, and Sergius and Bacchus resonate strangely in modern American ears. Culturally, most twentieth-century Americans consider marriage to be an institution that mtrinsically imvolves different- rather than same-sex partners. Although some Americans are willing to tolerate same-sex relationships, and even to give them some eupheimstic sanction, few consider them to be "real" marriages. The law reflects these cultural attitudes. For example, the most recent edition of Black's Law Dictionary defines "marriage" as the "legal status, condition, or relation of one man and one woman united in law for life, or until divorced, for the discharge to each other and the community of the duties legally incuinbent on those whose association is founded on the distinction of sex." 4

This cultural and legal consensus denying the legitimacy of samesex marriages has been under siege for over twenty years. Since the Stonewall riots of June 1969,5 gay men, lesbians, and bisexuals have

3 Their story will be told in John Boswell, What God Has Joined Together: Same-Sex Unions in the Christian Tradition (forthcoming 1994) (on file with Virginia Law Review Association).

${ }^{4}$ Black's Law Dictionary 972 (6th ed. 1990) (emphasis added); accord 3A Norman J. Singer, Sutherland Statutory Construction $\S 68.02$ (5th ed. 1992); 52 Am. Jur. 2d Marriage $\S 1$ (1970).

5 The Stonewall Riots occurred on the nights of June 27 and 28, 1969, when the gay and lesbian patrons of the Stonewall Bar fought back against a routine police raid of the bar. See Toby Marotta, The Politics of Homosexuality 71-99 (1981). 
come out of the closet and claimed our identity in great numbers. Many of these individuals have formed same-sex relationships, which members of the gaylesbian commumity have long referred to as "marriages." A number of these couples have insisted that the state recognize these marriages on the same terms that it recognizes different-sex marriages. At present, however, states have refused to recognize same-sex marriages, and none of the publicized lawsuits seeking such recognition has yet succeeded, nor have similar legislative efforts.

Opponents of same-sex marriage argue that the concept is oxymoronic. Marriage, they say, must imvolve a inan and a woman because (1) that is the definitional essence of marriage, (2) the JudeoChristian tradition requires it, and/or (3) the modern Western nationstate has structured society around the assumption that only differentsex marital unions are allowed. Proponents of same-sex marriage dispute and often ridicule these assertions. Thus far, neither side lias analyzed these arguments in the context of the history of marriage itself. That is the project of this Article.

Part II, the heart of this Article, recounts the history of same-sex marriage, synthesizmg scholarship in the fields of social anthropology, ethnograpliy, mythology, comparative literature, sociology, and ecclesiastical history. Most of the scholarship is of recent vintage, reflecting the post-Stonewall imterest in the topic. ${ }^{6}$ This contemporary hiterature tends to be sympathetic to gaylesbian concerns, and much of it is written by openly bisexual, lesbian, and gay scholars. The same can be said of this Article, for I also share the methodological perspective of this new scholarship-social constructionism-which I explain in Part $\mathrm{I}$.

A social constructionist history emphasizes the ways in which marriage is "constructed" by society over time, with "exclusions" from

6 Social anthropologists became interested in this phenomenon earlier than historians, legal scholars, and others. Consider the following findings:

In 49 (64 percent) of the 76 societies other than our own for which information is available, homosexual activities of one sort or another are considered normal and socially acceptable for certain members of the community.

$\ldots$

... In many cases this [same-sex] behavior occurs within the framework of courtship and marriage, the man who takes the part of the female being recognized as a berdache and treated as a woman. In other words, a genuine mateship is involved.

Clellan S. Ford \& Frank A. Beach, Patterns of Sexual Behavior 130-31 (1951) (surveying the sexual practices, mores, and institutions of 76 societies) (footnote omitted). 
the institution being viewed as reflecting larger social power relations. Thus, the exclusion of same-sex couples from marriage in America is an expression of our society's persecution of sexual orientation minorities-lesbians, gay men, and bisexuals. Our insistence that inarriage be an option available to us is part of an historical process by which the victims of society's dividing practice (sexual deviation) have coine to resist and defy the power of that stigma. This Article situates that resistance in the larger history of Western culture's shifting attitudes toward same-sex intimacy, and in the even larger context of other cultures' more favorable attitudes toward same-sex intimacy.

Part III explores the miplications of this history, imitially addressing debates within the gay, lesbian, and bisexual commumity about whether we even should be seeking the right to marry (I argue that we should), and then turning to the legal arguments developed in Part I. Tne history has both "defensive" and "offensive" argumentative power. It reveals the traditional arguments agamst same-sex marriage to be seriously defective: the definitional argument essentializing marriage around male-female intimacy is factually wrong; the argument from Judeo-Christian tradition is hypocritical, given early Christianity's tolerance of same-sex imtimacy; and the pragmatic argument is revealed to rest upon a normatively questionable status quo.

The history of same-sex marriage also has offensive, or affirmative, persuasive power. I offer it to the lesbian, bisexual, and gay community as part of a collective effort to retrieve our history, which has been suppressed and denied. And I offer it to the legal community as part of our larger narrative: same-sex unions have been a valuable institution for most of huinan history and in most known cultures. Social and rehgious mores in most cultures, including Western culture at certain times, have valorized same-sex unions for most of the same reasons they have valorized different-sex unions. Cultures, such as that of the recent West, that deny same-sex unions do so to suppress and persecute a homosocial minority. The process of suppression is an ugly one. For the same reasons that law ended its prohibition of interracial marriages im 1967, it should end its prohibition of same-sex marriages now. 


\section{The Legal Arguments for AND Against SAME-SEX MARRIAGE}

The intellectual debate over same-sex marriage in American law has been a twenty-year conversation largely conducted within the framework of liberal theory. The post-Stonewall period of gay rights activisin thrust the issue onto the nation's policy agenda, as gay and lesbian couples came out and began to insist on legal recognition of their relationships. These couples and their advocates relied on rights-oriented arguments, asserting that same-sex couples are not materially different from different-sex couples and should therefore be given the saine legal treatinent as a matter of constitutional or statutory right.

These arguinents have recently succeeded in gaining same-sex couples some of the same benefits regularly bestowed upon differentsex couples in the private sector and under local doinestic partnership ordinances. They have thus far been unsuccessful, however, in gaming state-wide recognition of same-sex unions as marriages. The reasons given by opponents of same-sex inarriage are also grounded in hiberal rhetoric. With respect to the institution of marriage, these opponents argue, saine-sex couples are simply not similar to differentsex couples. Because inarriage definitionally, inorally, and practically requires a inan and a woinan, there is no constitutional or statutory "right" for same-sex couples to marry.

Why have liberal arguinents been so unavailing for those advocating same-sex marriage? Social constructionist thought suggests that liberal theory's lostility to same-sex inarriage derives not froin any internal logic but instead froin cultural attitudes-specifically, the way American society has constructed both inarriage and hoinosexuality. Just as interracial inarriage was portrayed in such a way as to isolate African Americans from inainstreain society, so prohibitions against saine-sex marriage help to preserve the subordination of gays, lesbians, and bisexuals within society. Nonetheless, just as there was no neutral way for liberal theory to justify prohibiting interracial inarriage yesterday, so there is no neutral way to justify prohibiting samesex inarriage today.

\section{A. Liberal Arguments for Same-Sex Marriage}

Before 1969, the notion of a same-sex couple entering into statesanctioned inarriage seemed culturally and legally iniplausible in this 
country. Even though many same-sex couples in American history entered into the functional equivalent of marriage or, surprisingly enough, were legally inarried, these traditions were suppressed or ignored. The Stonewall riots changed all that, however, as gay inen, lesbians, and bisexuals came out of the closet in substantial numbers. Many of these newly-hiberated couples formed openly committed relationships functionally similar to different-sex inarriages. As part of this demand for acknowledgment or acceptance, inany activists sought legal recognition of same-sex inarriages on the same terms as different-sex marriages, as part of a general inovement to end all forms of state discrimination against lesbians, gay inen, and bisexuals.

For twenty years, gay activists have confronted the legal systeinmainly the courts-demanding that it end its discrimination against same-sex marriages. Three types of argnments have been made in support of these demands. ${ }^{7}$ First, state refusal to recognize same-sex marriages violates the right to marry, which the Supreme Court inferred from the Due Process Clause im Loving v. Virginia ${ }^{8}$ Loving invalidated state laws prohibiting different-race marriages in response to arguments that they violated African Americans' right to equal protection and interracial couples' due process right to marry. Subsequent cases have emphasized that the freedom to inarry the person of one's choosing stands as a fundamental due process right recognized for poor people and even prisoners and that this right can only be abridged to further an important or coinpelling state interest. ${ }^{9}$ Gay activists and friendly commentators argue that by refusing to allow saine-sex couples to add a legal sanction to their relationships, states violate same-sex couples' constitutional right to marry, a position

7 For sources presenting the rights-oriented arguments, see Nan D. Hunter, Sherryl E. Michaelson \& Thomas B. Stoddard, The Rights of Lesbians and Gay Men: The Basic ACLU Guide to a Gay Person's Rights 75-78 (3d ed. 1992); Alissa Friedman, The Necessity for State Recognition of Same-Sex Marriage: Constitutioual Requirements and Evolving Notions of Family, 3 Berkeley Women's L.J. 134 (1987-88); Rhonda R. Rivera, Our Straight-Laced Judges: The Legal Position of Homosexual Persons in the United States, 30 Hastings L.J. 799, 874-78 (1979); Editors of the Harv. L. Rev., Sexual Orientation and the Law 95-101 (1990).

8388 U.S. 1 (1967).

${ }^{9}$ See Turner v. Saffey, 482 U.S. 78 (1987) (holding that the state cannot, without compelling reason, forbid prison inmates from marrying while in prison); Zablocki v. Redhail, 434 U.S. 374 (1978) (finding that the state cannot forbid a person with outstanding support obligations from remarrying); Boddie v. Connecticut, 401 U.S. 371 (1971) (declaring that the state cannot condition divorce upon payment of fees that poor people cannot afford). 
which is just as irrational as previous state action prohibiting different-race marriages. ${ }^{10}$

In addition, gaylegal theorists and feminists have argued that by prohibiting same-sex marriage, states engage in sex discrimination, thereby violating the federal Equal Protection Clause and/or state equal rights amendments. ${ }^{11}$ Although the state will give a inarriage hicense to virtually any woinan-1nan couple, no license will be dispensed to any woman-woman couple. As a consequence, the state is discriminating agaimst the latter couple simply because the second partner is a woman and not a man. That, the argument goes, is de jure sex discrimination, which is unconstitutional unless justified by a coinpelling state interest. A deeper form of the sex discrimination argument, developed by Sylvia Law, is that any effort by the state to hardwire sex differences into the concept of inarriage perpetuates traditional sex-based stereotypes of man-as-breadwinner and womanas-housekeeper. ${ }^{12}$ Same-sex marriage is required by a genderless Constitution precisely because it unlinks functional roles from sex stereotypes.

Fimally, under a gayliberal analysis, prohibiting saine-sex marriages is invalid precisely because it discriminates against lesbian and gay couples. Many scliolars ${ }^{13}$ and soine judges ${ }^{14}$ have argued that statutes

10 See Friedman, supra note 7, at 155-57; Herma H. Kay, Private Choices and Public Policy: Confronting the Limitations of Marriage, 5 Austl. J. Fam. L. 69 (1991); Editors of the Harvard Law Review, supra note 7, at 95-98.

11 See Sylvia A. Law, Homosexuality and the Social Meaning of Gender, 1988 Wis. L. Rev. 187, 218-21, 230-33; Claudia A. Lewis, Note, From This Day Forward: A Feminine Moral Discourse on Homosexual Marriage, 97 Yale L.J. 1783 (1988).

12 Law, supra note 11 , at 232.

13 The most sustained case for strict scrutiny is made in Carol S. Steiker, Note, The Constitutional Status of Sexual Orientation: Hoinosexuality as a Suspect Classification, 98 Harv. L. Rev. 1285 (1985). For other scholarly works on this issue, see John H. Ely, Deinocracy and Distrust 162-63 (1980); Bruce A. Ackerman, Beyond Carolene Products, 98 Harv. L. Rev. 713 (1985); Elvia R. Arriola, Sexual Identity and the Constitution: Homosexual Persons as a Discrete and Insular Minority, 10 Wonnen's Rts. L. Rep. 143 (1988); Richard Delgado, Fact, Norm, and Standard of Review-The Case of Hoinosexuality, 10 U. Dayton L. Rev. 575 (1985); Cass R. Sunstein, Sexual Orientation and the Constitution: A Note on the Relationship Between Due Process and Equal Protection, 55 U. Chi. L. Rev. 1161 (1988). For an excellent cautionary piece, sce Janet E. Halley, The Politics of the Closet: Towards Equal Proteetion for Gay, Lesbian, and Bisexual Identity, 36 UCLA L. Rev. 915 (1989).

14 The leading judicial decision applying strict scrutiny to sexual orientation classifications is Judge William A. Norris' panel opinion in Watkins v. United States Army, 847 F.2d 1329, 1345-49 (9th Cir. 1988), aff'd on other grounds, 875 F.2d 699 (9th Cir. 1989) (en banc) (affirming the panel decision on the ground of equitable estoppel, declining to reach the 
classifying individuals on the basis of their sexual orientation should trigger heightened equal protection scrutiny. Under such scrutiny, state prohibitions of same-sex inarriage ought to be invalidated because no coinpelling state interest justifies treating gay couples differently froin heterosexual couples. Like the sex discrimination arguinent, this claim can soinetimes be asserted on the basis of statutory as well as constitutional rights. A number of jurisdictions have enacted human rights statutes that broadly prohibit discriminating agamst lesbians, gay inen, and bisexuals on the basis of their sexual orientation. ${ }^{15}$ In the District of Columbia, for exainple, the Human Rights Act prohibits the government froin discriminating on the basis of sexual orientation or froin adopting policies that have a discriminatory effect upon sexual orientation minorities. ${ }^{16}$ Because denying inarriage licenses has such an effect on lesbian and gay couples, the District's refusal to issue hicenses is arguably unlawful sexual orientation, as well as sex, discrimination.

Althougl1 such rights-based arguments are naturally raised in litigation contexts, lesbian and gay advocates have rehed on similar pitches in lobbying for support in the executive and legislative branches. Activists have brought these constitutional and statutory arguinents to state attorneys general, in addition to petitioning state legislatures to adopt statutes allowing saine-sex inarriages.

constitutional issues, and withdrawing the district court and panel opinions). Judge Norris' views were favorably cited in Commonwealth v. Wasson, 842 S.W.2d 487, 499 (Ky. 1992). For dicta supporting Judge Norris' views, see Gay Rights Coalition v. Georgetown Univ., 536 A.2d 1, 36 (D.C. Ct. App. 1987) (opinion of Mack, J.) (en banc).

is California, Connecticut, the District of Colunibia, Hawaii, Massachusetts, New Jersey, Vermont, and Wisconsin have statutes prohibiting job discrimination on the basis of sexual orientation. See Cal. Lab. Code § 1102.1 (West Supp. 1993); Conn. Gen. Stat. Ann. §§ 46a81c (West Supp. 1993); D.C. Code Ann. §§ 1-2501, -2512 (1981); Haw. Rev. Stat. §§ 368-1, 378-2 (Supp. 1992); Mass. Gen. Laws Ann. ch. 151B, § 4 (West Supp. 1993); N.J. Stat. Ann. $\S \S 10: 5-4,-12$ (West Supp. 1993); Vt. Stat. Ann. tit. 3, § 961(6) (Supp. 1992); id. tit. 21 $\S \S$ 495(a), 1726(a)(7); Wis. Stat. Ann. $\S 101.22$ (West 1988 \& Supp. 1991). The District of Columbia, Massachusetts, New Jersey, Vermont, and Wisconsin also prohibit businesses from engaging in such discrimination when providing services in places of "public accontmodation." See D.C. Code § 1-2519 (1981); Mass. Gen. Laws Ann. ch. 272, §§ 92A, 98 (West 1990); N.J. Stat Ann. $\S \S 10: 5-4,-12$ f (West 1993); Vt. Stat. Ann. tit 9, § 4502(a) (Supp. 1992); Wis. Stat. Ann. $\S 101.22(9)$ (West Supp. 1990).

16 The District's anti-discrinination rules were applied to District government agencies in Dickerson v. D.C. Dep't of Human Servs., No. 89-465-PA(N) (D.C. Comn'n on Human Rights, 1991). 


\section{B. Liberal Arguments Against Same-Sex Marriage}

As of October 1993, none of the legal efforts to gain statewide recognition of same-sex marriage im the Umited States has been successful, ${ }^{17}$ though several efforts are still pending and one (im Hawaii) has obtained a ruling that the state must show a compelling interest for its exclusion of same-sex couples from marriage. Same-sex marriage opponents-primarily state attorneys general defending state statutes, state court judges interpreting and upholding those statutes, and interest group opponents (the Catholic Church and fundamentalist Protestant denommations) - have argued that the concept is a contradiction in terms. Marriage must involve a man and a woman, they contend: a relationship between people of the same sex simply cannot be a marriage, as a matter of definition, morality, and Western practice.

The main argnment against same-sex marriage is definitional: marriage is necessarily different-sex and therefore cannot include sainesex couples. Hence, the authors of any statute that talks of "marriage" could have only conteinplated different-sex couples, even if the statute is not gendered, i.e., does not use the specific terms "husband"

17 For leading judicial decisions rejecting arguments for same-sex marriage, see Adams v. Howerton, 486 F. Supp. 1119 (C.D. Cal. 1980), aff'd on other grounds, 673 F.2d 1036 (9th Cir. 1982); Singer v. Hara, 522 P.2d 1187 (Wash. Ct. App. 1974); Jones v. Hallahan, 501 S.W.2d 588 (Ky. 1973); Baker v. Nelson, 191 N.W.2d 185 (Minn. 1971), appeal dismissed, 409 U.S. 810 (1972); see also Baehr v. Lewin, No. 91-1394-05 (Haw. Cir. Ct. Sept. 3, 1991) (rejecting plaintiffs' equal protection claim), vacated and remanded, 852 P.2d 44 (Haw. 1993); Succession of Bacot, 502 So. 2d 1118, 1127-30 (La. Ct. App.) (holding that a man cannot be a "concubine" of another man), writ denied, 503 So. 2d 466 (La. 1987); Jennings v. Jennings, 315 A.2d 816, 820 n.7 (Md. Spec. Ct. App. 1974) (explaining that "Maryland does not recognize a marriage between persons of the same sex"); In re Estate of Cooper, 564 N.Y.S.2d 684,687 (N.Y. Sup. Ct. 1990) (refusing to "elevate[ ] homosexual unions to the same level achieved by the marriage of two people of the opposite sex"); Anonymous v. Anonymous, 325 N.Y.S.2d 499 (N.Y. Sup. Ct. 1971) (stating that "[m]arriage is and always has been a contract between a man and a woman"); De Santo v. Barnsley, 476 A.2d 952 (Pa. Super. Ct. 1984) (holding that persons of the same sex cannot contract a common law marriage); Slayton v. Texas, 633 S.W.2d 934, 937 (Tex. Ct. App. 1982) (stating that same-sex marriage is impossible in Texas).

The attorneys general of at least six states have issued opinions that their states' marriage laws prohibit same-sex marriages and can constitutionally do so. They are $190 \mathrm{Op}$. Att'y Gen. Ala. 30 (1983); 1975 Colo. AG LEXIS 38; 77 Op. Att'y Gen. Kan. 248 (1977); 1978 Miss. AG LEXIS 684; 1976 S.C. AG LEXIS 423; 88 Op. Att'y Gen. Tenn. 43 (1988). 
and "wife." Typical is the Kentucky Court of Appeals' discussion in Jones v. Hallahan: ${ }^{18}$

Kentucky statutes do not specifically prohibit marriage between persons of the same sex nor do they authorize the issuance of a marriage hicense to such persons.

Marriage was a custom long before the state commenced to issue licenses for that purpose. For a time the records of marriage were kept by the churcl1. ... [M]arriage has always been considered as the union of a man and a woman and we have been presented with no authority to the contrary.

It appears to us that appellants are prevented from marrying, not by the statutes of Kentucky or the refusal of the County Court Clerk of Jefferson County to issue them a license, but ratlier by tlieir own mcapability of entering into a marriage as that terin is defined. ${ }^{19}$

Any argument focusing on statutory interpretation is naturally dispatched by this definitional approach, because all of the state marriage statutes-whether gendered or not-employ the term "marriage."20 Although the Kentucky court rehed on history and tradition to define marriage, other courts have approached the issue as a functional inatter, but with the same result: same-sex unions are not "marriages" because the purpose of inarriage is procreation, which saine-sex couples cannot accomphsh. ${ }^{21}$

Courts have also invoked the definitional arguinent as a basis for rejecting constitutional challenges founded upon Loving's right to marry. The leading case is the Washington Court of Appeals' decision in Singer v. Hara, ${ }^{22}$ which not only rejected a federal due process argument based upon Loving, but also an argument based upon the state equal rights ainendment:

Given tlie defimition of marriage wlicli we have enunciated, the distinction between the case presented by appellants [two men] and

\footnotetext{
18501 S.W.2d 588 (Ky. 1973).

19 Id. at 589 (emphasis added and footnote omitted).

20 See id. at 590 (stating that "the relationship proposed by the appellants does not authorize the issuance of a marriage license because what they propose is not a marriage"); Bacot, 502 So. 2d at 1130; Baker, 191 N.W.2d at 185-86; Singer, 522 P.2d at 1191.

21 See Baker, 191 N.W.2d at 186. On this view, procreation at least must be a potential purpose. Because same-sex couples cannot create children by themselves (a third different-sex person must be introduced, e.g., a sperm donor or a surrogate), defining marriage in this way also excludes different-sex couples who are unable to bear children.

22522 P.2d 1187 (Wash. Ct. App. 1974).
} 
[that] presented in Loving . . . is apparent. In Loving . . . the parties were barred from entering into the marriage relationship because of an impermissible racial classification. There is no analogous sexual classification involved in the instant case because appellants are not being denied entry into the marriage relationship because of their sex; rather, they are being demed entry into the nrarriage relationship because of the recognized definition of that relationship as one which nuay be entered into only by two persons who are nienibers of the opposite sex. ${ }^{23}$

By defining marriage as essentially different-sex, the court thus was able to avoid the charge that the state was creating an imvidious discrimination by denying hicenses to same-sex couples. ${ }^{24}$

The opponents of same-sex marriage have also attempted to show that defining marriage to mclude only different-sex couples is justified morally, to preserve family values and traditional ethical notions. Accordingly, the second type of oppositiomst argument invokes cominunity values, including the antihoinosexual teachings of the Old Testament. The federal court in Adams v. Howerton ${ }^{25}$ made just such a definitional argument by linking it to traditional Judeo-Christian morahity:

The definition of marriage, the rights and responsibilities implicit in that relationship, and the protections and preferences afforded to marriage, are now governed by the civil law. The English civil law took its attitudes and basic principles from canon law, which, in early times, was administered in the ecclesiastical courts. Canon law in both Judaisin and Christianity could not possibly sanction any marriage between persons of the same sex because of the vehement condemnation in the scriptures of both religions of all honısexual relationships. Thus there has been for centuries a coinbination of scriptural and canonical teaching under which a "nrarriage" between persons of the same sex was unthinkable and, by definition, impossible. $^{26}$

23 Id. at 1192.

24 See also Baker, 191 N.W.2d at 186-87, in which the court distinguished Loving from the right to privacy cases on the ground that the latter emphasized procreation's essential link to marriage. For this reason, "in common sense and in a constitutional sense, there is a clear distinction between a marital restriction based merely upon race and one based upon the fundamental difference in sex." Id. at 187.

25486 F. Supp. 1119 (C.D. Cal. 1980), aff'd on other grounds, 673 F.2d 1036 (9th Cir. 1982).

26 Id. at 1123 (footnotes omitted). 
More dramatically, the District of Columbia Superior Court's decision in Dean v. District of Columbia ${ }^{27}$ invoked passages from Genesis, Deuteronoiny, Matthew, and Ephesians to support its holding that "societal recognition that it takes a man and a woman to form a marital relationship is older than Christianity itself," 28 an apparent reference to Adam and Eve. Although these decisions rest upon a suspiciously sectarian vision of morality, they could have invoked general "fanilly values" to the sanie effect, as other courts and commentators have done. ${ }^{29}$

Traditional Judeo-Christian morality works against same-sex marriage in another way. Its sexual mores are reflected in state sodoiny laws-currently found in inore than twenty states-which are invoked in their relevant jurisdictions as a basis for opposing same-sex marriages. The District of Columbia Superior Court im Dean believed that allowing sanie-sex marriages would contradict expressed public pohicy where the sexual conduct at the heart of those inarriages was criminalized. ${ }^{30}$ The Supreine Court in Bowers v. Hardwick ${ }^{31}$ suggested that "millennia of moral teaching"32 can protect sodoiny laws against due process attack. The same idea is potentially apphicable to marriage rights.

A third argument against sanie-sex marriage appeals to pragniatisin. Even if unconstranied by formal definitions and traditional

27 No. CA 90-13892 (D.C. Super. Ct. Dec. 30, 1991), appeal docketed, No. $92-737$ (D.C. Ct. App. June 2, 1992).

28 Id., slip op. at 18-21. A similar trope was deployed in Baker, 191 N.W.2d at 186 ("The institution of marriage as a union of man and woman, uniquely involving the procreation and rearing of children within a family, is as old as the book of Genesis.").

29 See G. Sidney Buchanan, Same-Sex Marriage: The Linchpin Issue, 10 U. Dayton L. Rev. 541, 567 (1985) ("The majority [of society], therefore, may reasonably believe that legal recognition of same-sex marriage . . . would impair the ability of opposite-sex marriage to advance the individual and community values that it has traditionally promoted."); see also id. at 559-60 (arguing that the state ought to be able to inplement community inoral standards by discouraging conduct inconsistent with those standards).

${ }^{30}$ See Dean, slip op. at 9 (" $[\mathrm{L}]$ egislative authorization of homosexual, same-sex marriages would constitute tacit state approval or endorsement of the sexual conduct, to wit, sodomy, coininouly associated with homosexual status - conduct deemed by society to be so inorally reprehensible as to be a criminal offense in the District of Columbia and many other jurisdictions.") (footnotes onitted). The District subsequently repealed its sodomy law in 1993, however.

31478 U.S. 186 (1986).

32 Id. at 197 (Burger, C.J., concurring). Though the Chief Justice's phrasing is more quotable, the majority opinion relied on a similar argument. See id. at 192-94. 
morality, the pragmatist might still be reluctant to allow same-sex marriages if such marriages would prove impractical or unjustified under a social cost-benefit analysis. Judge Richard Posner's Sex and Reason presents just such a pragmatic case against permitting samesex marriage at this time. ${ }^{33}$ Recognizing same-sex relationships as marriage would be problennatic, he suggests, because it would "be widely interpreted as placing a stamp of approval on homosexuality."34 Moreover, such recogntion would carry an "information cost" in that the social value of knowing someone is married would be somewhat reduced as the term is broadened. ${ }^{35}$ Fmally, acknowledging same-sex marriages would have a variety of "collateral effects, simply because marriage is a status rich in entitlements," many of which were not designed with saine-sex couples in mind. ${ }^{36}$

This last point is the most important. If the state suddenly recognized same-sex marriages, employers would have to rethink whether to provide fringe benefits once many of their newly married gay and lesbian employees claimed spousal coverage. Legislatures would become embroiled in a spate of controversies about which (if any) marriage entitlements they would deny to same-sex couples. If any entitlements were denied, state attorneys general would then be faced with the prospect of hitigating the constitutionality of such discrimination. Finally, state agencies and private employers would have to perform new cost-benefit analyses to recalibrate the health care, spousal leave, and other benefits now accorded married couples.

For the Posnerian pragmatist, even if the moral objections to samesex marriage have become attenuated after Stonewall, the concept of different-sex inarriage is so culturally enibedded in our society-and mterwoven throughout its social and economic institutions-that pohcyınakers (especially unelected judges) cannot simply legalize same-sex marriages and expect that society will acquiesce without

33 Richard A. Posner, Sex and Reason 311-13 (1992).

34 Id. at 311 . Judge Posner does not discuss the argument that, by permitting convicted rapists, spouse abusers, and misogynists to marry their victims, the state might be widely interpreted as placing a stamp of approval on rape, spouse abuse, and misogyny.

35 Id. at 312. Judge Posner concedes that denying same-sex marriages carries what I consider to be even more severe "imformation costs" for those in a same-sex union: the parties cannot signal their level of commitment by getting married or deliberating the issue.

36 Id. at 313. This point is reviewed critically in William N. Eskridge, Jr., A Social Constructionist Critique of Posner's Sex and Reason: Steps Toward a Gaylegal Agenda, 102 Yale L.J. 333, 352-59 (1992). 
experiencing turmoil and disruption. On the other hand, pragmatic concerns such as those articulated above might be viewed less as arguments against saine-sex marriage smiphiciter, and more as arguments that this new institution cannot be thrust upon society abruptly by unelected judges. Instead, advocates should advance the idea incrementally, starting with domestic partnership ordinances and working up to saine-sex marriages over time.

\section{Toward a Gaylegal Response: Social Constructionism}

In response to the definitional, moral, and pragmatic arguments discussed above, the gaylegal community and its allies have developed hberal nieta-arguments. The nrain pitch has been hibertarian: the state should allow people to marry whoniever they desire so long as there are no grave third-party effects of a tangible and siguificant nature. Under a libertarian view, the definitional argunient is circular-the state cannot defend its prohibition of saine-sex inarriages siniply because it does not believe them to be marriages. Cases upholding the right to marry require tlie state to provide an independent reason, one grounded upon third-party harms and not just moral disapproval ${ }^{37}$ or a sectarian understandimg of marriage. ${ }^{38}$ Also, as a practical matter, state prohibition of saine-sex marriage serves none of the family values trunipeted by those who resist the institution. By denying gay and lesbian couples the legal protections and household stability facilitated by niarriage laws, the state only impedes our ability to create "families we choose."39

These hbertarian counterarguments have been uniformly unsuccessful, for reasons having to do witlı precedent (the Bowers problen with any argument based on the Due Process Clause), the doctrinal weakness of the right-to-marry line of cases, ${ }^{40}$ and cultural resistance

37 This is supported not only by Loving v. Virginia, 388 U.S. 1 (1966), whose validation of different-race marriages came in the face of widespread social disapproval, but also by Palniore v. Sidoti, 466 U.S. 429 (1984), which held that majority "prejudice" generally could not be the basis for state penalties. Id. at 434 . Both cases expressly disapproved of state acts iniposing punishment as a means by which to accommodate racial prejudice.

38 See Sherryl E. Michaelson, Note, Religion and Morality Legislation: A Reexamination of Establishment Clause Analysis, 59 N.Y.U. L. Rev. 301, 307-11 (1984).

${ }^{39}$ See Friedman, supra note 7, at 160-69; see also Kath Weston, Families We Choose: Lesbians, Gays, Kinship (1991) (coining the phrase).

40 See Earl M. Maltz, Constitutional Protection for the Right to Marry: A Dissenting View, 60 Geo. Wash. L. Rev. 949 (1992). 
to the very idea of same-sex marriage generally and "homosexuals" im particular. Perhaps a better line of liberal meta-argument is the egalitarian pitch: it is discrimination, pure and simple, to deny same-sex couples the same marriage rights as different-sex couples. Denying same-sex couples marriage licenses is a clear case of discrimination, therefore directly implicating the Equal Protection Clause, which renders any gendered state policy suspect (or quasi-suspect). The policy of the Equal Protection Clause is also strongly imphicated, because such discrimination is animated by the sorts of irrational prejudices and gender stereotypes that have been cleared away im other contexts. Bowers by its terms does not apply to equal protection claims. The Hawaii Supreme Court recently accepted a version of the egalitarian arguinent, while decisively rejecting the bibertarian pitch, and has required the state to justify its exclusion of same-sex couples. ${ }^{41}$

Except for the Hawañ decision, egalitarian claims have suffered the same fate as hibertarian ones. A difficulty they share is that both operate under a faith that our hberal polity will assure bisexuals, gay men, and lesbians the same "neutral" protection of our autonony (the hibertarian point) and the same "neutral" protection against arbitrary classifications (the egahtarian point) that are assured all citizens in a liberal polity. Yet liberalism has had no bite for us: our liberty has been defined away by denying our capacity for making a marital "choice," and our equality lias been comproimsed by making homosexuality a suspect "group" rather than a suspect "classification." This poses a clrallenge for the gaylegal commurity-to escape confining liberal conceptualizations of our position. Social constructiomist theory has provided a different way to conceptualize tlie case for same-sex inarriage.

At the same time the gaylegal community was struggling to obtain equal rights, we were also engaged in an intellectual struggle to understand why American society has been so hysterically hostile to us. ${ }^{42}$ What emerged from this struggle was widespread agreeinent among gaylesbian intellectuals that sexual orientation as a category is socially constructed, and that the modern West's obsession with that category

41 See Baehr v. Lewin, 852 P.2d 44, 67 (Haw. 1993).

42 This latter struggle has many parallels with feminist and critical race theory and, indeed, was influenced heavily by feminist thought in particular. See, e.g., Gayle Rubin, Thinking Sex: Notes for a Radical Theory of the Politics of Sexuality, in Pleasure and Danger 267 (Carole S. Vance ed., 1984). 
is part of a complex web of attitudes and institutions that work to subordinate whole groups of people, including straight, bisexual, and lesbian women as well as bisexual and gay men. ${ }^{43}$ There is now a substantial literature, grounded im philosophy, history, anthropology, and sociology, that develops social constructiomst theory as a way of thinking about culture generally, and sexuality and marriage in particular.

Social constructionism provides a framework for evaluating samesex inarriages that differs from traditional liberal thought. This framework can be expressed as three hypotheses. First, inarriage is not a naturally generated institution with certain essential eleinents. Instead, it is a construction that is linked with other cultural and social institutions, so that the old-fashioned boundaries between the public and private hife melt away. Second, the social construction of institutions like marriage is not and cannot be neutral, for it involves the playing out of a society's power relationships. Categorically denying same-sex inarriage relates not only to the notion that procreation is essential to marriage, but inore deeply to Americans' fears of hoinosexuality (itself an historically recent construct), just as denying different-race marriage was related to Ainericans' racial anxieties (also an historical construct). Third, the social construction of marriage is dynamic. Linked as it is to other institutions and attitudes, narriage will change as they change. Conceptualized around certain practices dividing society's constituents, marriage should change as the subordinated groups identify their own oppression and decide to resist it.

These social constructionist hypotheses have many implications for the legal debate over same-sex marriage, but I can hardly explore those inplications without offering some evidence supporting the hypotheses theinselves. As evidence, $I$ offer the following history of saine-sex unions.

43 For the leading sources, see 1 Michel Foucault, The History of Sexuality (Robert Hurley trans., Pantheon Books 1978) (1976); Mary McIntosh, The Homosexual Role, 16 Soc. Probs. 182 (1968), reprinted in The Making of the Modern Homosexual 30-49 (Kenneth Plummer ed., 1981); see also Forms of Desire: Sexual Orientation and the Social Constructionist Controversy (Edward Stein ed., 1990) (exploring social constructionism); Sexual Meanings: The Cultural Construction of Gender and Sexuality (Sherry B. Ortner \& Harriet Whitehead eds., 1981) (same). 


\section{SAME-SeX UNions in Other Times AND OTher Cultures}

If one read only legal materials, one would think same-sex marriage an historical and cultural oddity, if not freakish and perverse. Yet historians, social anthropologists, and scholars of comparative literature have been writing about same-sex marriage for most of this century, with a boomlet in the last two decades. Same-sex unions grounded upon affection, sexual attraction, or a mixture thereof are commonplace in hunian history, and the following account is my effort to introduce this scholarship to a legal audience.

Several general points should be made at the outset. The story I am going to tell is episodic and fragmentary. A thorough history of inarriage itself has yet to be written, ${ }^{44}$ and may never be written, because the records of people's everyday lives no longer exist or exist in hardto-decipher form. ${ }^{45} \mathrm{~A}$ history of same-sex unions will be even more fragmentary, because same-sex relationships liave not comprised the predominant form of mateship in most cultures and have been systematically suppressed in the West for several centuries.

Another complication involves terminology. Human relationships and compamonships assume as many different forms as there are societies, and generalizing about institutions across cultures is perilous. Nonetheless, employing some categories may help to inake sense of the data. I shall thus use the term "same-sex umions" to refer to any kind of culturally or legally recognized institution whereby people of the same sex are bonded together in relationships for sexual or other reasons of affinity. Included within the general category of same-sex unions will be same-sex "relationships," which are culturally but not legally recognized in the society, and same-sex "marriages," which are given some kind of legal recognition. ${ }^{46}$

44 However, there have been many excellent monographs. E.g., James A. Brundage, Law, Sex, and Christian Society in Medieval Europe (1987); John R. Gillis, For Better, For Worse: British Marriages, 1600 to the Present (1985); David Herlihy, Medieval Households (1985); Sarah B. Pomeroy, Goddesses, Whores, Wives, and Slaves (1975); Tamara K. Hareven, The History of the Family and the Complexity of Social Change, 96 Am. Hist. Rev. 95 (1991).

45 Thus we do not know when marriage became institutionalized in most societies, or even the extent to which historical marriage-like institutions resemble marriages taking place today in current Western society.

46 Compare my approach with the more liberal approach taken by John Boswell in Christianity, Social Tolerance, and Homosexuality 26 (1980):

No marriages in ancient societies closely match their modern equivalents. Most were vastly more informal; some were more rigid. . . . No precise criteria could be specified 
Functional categories may also be useful, both descriptively and normatively. ${ }^{47}$ "Transgenerational" unions refer to intimate pairings of people of different generations or at least significantly different ages or levels of inaturity. These unions typically involve a mature person and a youthful one and tend to be temporary relationships. For these reasons, such relationships are more normatively questionable froin the perspective of Western values, though they may serve a cultural purpose froin the point of view of the societies in which they occur. Transgenerational relationships are often linked with inarriage, as a preparation for or a compleinent to one's different-sex inarriage, for example. "Transgenderal" unions involve two people of the saine sex, one of whoin assumes some of the roles and characteristics of the opposite sex. These unions can take the form of either relationships or marriages. Berdache marriages, such as that of We'wha, were transgenderal. Note that transgenderal unions accept society's concepts of gender (for the most part). Froni a feinimist point of view, these relationships might be questionable. Finally, a "coinpamionate" union, such as that between Sergius and Bacchus, involves a same-sex couple, each partner having equal status and neither necessarily assuming the role or identity of the opposite sex. Companionate unions are most similar to those that are typically valorized by most modern Western perspectives.

For narrative convenience, I have organized the history of same-sex unions into three segments: first, the pre-modern antecedents of Western (European) culture; second, Native American, African and Asian cultures, with a focus on the treatment of sanie-sex unions prior to Westermzation; and, third, the modern period, in which Western culture came to dominate the world. The first two segments reveal that in many coininunities, including pre-nodern Western society, saniesex marriage flourished. However, in the modern period, our third segment, one finds that society generally has suppressed same-sex inarriage.

as constituting a "legal" marriage during most of the period of this study: two people who lived together perinanently and whose union was recognized by the community were "married."

47 For a discussion of these typological terns, see generally David F. Greenberg, The Construction of Homosexuality 25-77 (1988) (providing a leading social history of homosexuality and distinguishing homosexual relationships on the basis of the relative social statuses of the persons involved). 


\section{A. Same-Sex Unions in Pre-Modern Western Cultures}

The early Egyptian and Mesopotamian societies that are considered important antecedents for Western culture apparently not only tolerated same-sex relationships, but also recognized such relationships in their culture, literature, and mythology. Evidence of same-sex marriage is at best indirect in these ancient societies, however. One finds shightly stronger and more direct evidence of same-sex marriages in Greek and early Roman culture, in imperial Rome, and in Western Europe for inuch of the Christian Middle Ages.

\section{The Ancient Near East (Egypt and Mesopotamia)}

Because there are so few surviving records pertaining to family and sexual matters, we know little of the most ancient cultures' specific practices, namely, those of Egypt, Mesopotamia, and their environs. However, after examining the few pertinent records (includimg legal documents), as well as the literature, myths, and artifacts of this period, one might tentatively conclude that inost ancient cultures did not prohibit same-sex relationships, nor did many stigmatize tliem. Although the evidence is debatable, some of the ancient cultures may liave treated same-sex relationships similarly to marriages involving different-sex partners.

The evidence of marital practices-wliether for different- or samesex unions-is particularly sparse for Egypt; few records illuininate the intimate practices of the region, and no authoritative legal texts survive. Yet some artifacts have depicted same-sex couples in familiar poses, perhaps providing evidence that Egyptian society at some points in its history was accepting of same-sex relationslips. For example, a tomb for two male courtiers of the Fifth Dynasty (circa 2600 B.C.) includes bas-reliefs of the "two men in intimate poses, lolding hands, embracing, noses touching," ${ }^{48}$ poses that are strikingly more erotic than those depicting different-sex couples in Egyptian tombs. ${ }^{49}$ Social historian David Greenberg argues that the men were lovers whose same-sex relationslip was apparently accepted by the state, because the Pharaoh provided their tomb. Indeed, the tomb of

\footnotetext{
48 Id. at 130.

49 Id. This is significant in part because Egyptian tomb art of that period was almost always stiffly posed, even for husband-and-wife figures.
} 
at least one Pharaoh, the renowned Ikhnaton, contains figures of the Pharaoh and his male consort posed even more intimately. ${ }^{50}$

The most imteresting evidence for same-sex coupling in ancient Egypt is imdirect. After living for several generations im Egypt, the Israehtes fied that land, ultimately settling in Canaan. Their rehigion was a conscious reaction to Egyptian customs, imcluding same-sex marriages, it appears. Chapter eighteen of Leviticus admoinshes the Israehites to avoid the "doings of the land of Egypt, wherein ye dwelt ... neither shall ye walk in their ordmances." "Subsequent passages im chapter eighteen identify specific practices: "Thou shalt not lie witl mankind, as with womankind: it is abomination."52 The imphication that same-sex intimacy was cominon im Egypt (and Canaan) is confirmed by the Sifra, an exegetic midrasl imterpreting the book of Leviticus. The Sifra says of chapter eighteen:
A. If "You shall not copy the practices of the land of Egypt . . . or of the land of Canaan,"
B. might one think that they are not to build their buildings or plant vineyards as they did?
C. Scripture says, "nor shall you follow their laws":
D. "I have referred only to the rules that were made for them and for their fathers and their fathers' fathers."
E. And what wonld they do?
F. A man would marry a man, and a woman wonld marry a woman, a man would marry a woman and her daughter, a woman would be married to two men.
G. That is why it is said, "nor shall you follow their laws."53

50 An unusual degree of intinacy is also shown in depictions of King Ikhnaton (1379-1362 B.C.) and his son-in-law and probable co-regent Smenkhare. They are shown together nude-a convention quite rare in Egyptian representations of royalty. On a stele, Ikhnaton strokes Sinenkhare under the chin. Smenkhare is given titles of endearment that had been used previously for Ikhnaton's concubimes and queen.

Id. This evidence is suggestive but not conclusive as to a same-sex union. It should also be noted that by the time of Ikhnaton Egyptian toinb art offered figures that were less stiffly posed.

51 Leviticus 18:3 (King Janes).

52 Id. 18:22; see id. 18:24, 27 (admomishing the Israelites from "these aboininations" that deffled "the nations," probably referring to Egypt and the nations in Canaan).

533 Jacob Neusner, Sifra: An Analytical Translation 74 (1988) (translating Chapter 193, entitled "Parashat Aharé Mot Parashah" 8). I am greatly indebted to Yair Chamudot for bringing this inaterial to iny attention. 
This evidence suggests a stronger possibility of institutionalized samesex intimacy or even marriage in Egypt and Canaan, though it is not conclusive evidence to that effect.

Similar to evidence in Egypt, Greenberg reports that Mesopotainian inonarchs, notably King Zimri-Lim of Mari and King Hammurabi of Babylon, had inale lovers akin to wives:

That there was no rehigious prohibition against homosexuality is clear not only from the existence of cnlt [homosexual] prostitution, but also from the text of an Almanac of Incantations, which contains prayers favoring, on an equal basis, the love of a man for a woman, a woman for a man, and a man for a man. ${ }^{54}$

In the third millennium B.C. generally, marital and familial relations were inostly fluid, with ancient records revealing women marrying more than one husband and often taking an important role in affairs. ${ }^{55}$

Additional evidence for Mesopotamian inores pertaiming to samesex relationships can be found in the most celebrated of the Mesopotamian myths, the epic of Gilgamesh. Written through a collective process over several generations, the epic describes the relationship between Gilgamesh, the great powerful ruler of Uruk, and Enkidu, a inale created by the gods to divert Gilgainesh from wreaking havoc in the world. ${ }^{56}$ Gilgamesh and Enkidu become comrades, friends, and probably lovers ${ }^{57}$ before Enkidu dies at the hands of the fates. Classicist David Halperin describes the relationship:

Enkidu is often called Gilgamesh's "brother" $(a h u)$. Moreover, Gilgamesh's feeling for Enkidu is explicitly modeled on sexual attraction: in the two dreains that presage the arrival of Enkidu, Gilgainesh takes pleasure in his vision of Enkidu as in a woman (though he does not take such pleasure in Enkidu himself when the latter finally arrives). The crucial phrase occurs only once (in the second dream) in the extant fragments of the Old Babylonian version, but the Assyrian version picks it up and repeats it relentlessly. The phrase itself has been variously rendered: E.A. Speiser translates, "[I loved it] and was drawn to it as though to a woman," whereas Jeffrey Tigay prefers, "[I loved it, and lik]e a wife I caressed it." Whatever the exact meaning

54 Id. at 126 (footnote omitted).

ss See Gerda Lerner, The Creation of Patriarchy 68-75 (1986).

56 See generally Jeffrey H. Tigay, The Evolution of the Gilgamesh Epic (1982) (tracing the historical development of the story of Gilgamesh).

57 Id. at 184 n.22. 
of the problematic term hababu, its implication is not in doubt: the word that describes Gilgamesh's anticipated attraction to Enkidu is also used to describe Enkidu's anticipated attraction to the prostitute from Uruk, with whom he mates for six days and seven nights. When Enkidu dies, moreover, Gilgamesh niourns for him like a widow (literally, "a wailing woman") and veils his corpse as if it were a bride. The point of these analogies to kin and objects of sexual desire seems to be that Enkidu's friendship affords Gilgamesh a proleptic taste of the pleasures of human sociality, including inarriage and patermity $\ldots . .58$

Because the epic of Gilgamesh was a collective project and achieved great popularity in ancient times, one might infer that its glorification of same-sex relationships had some resonance in the cultures of ancient Babylonia and Assyria. If so, Mesopotamian culture had some appreciation not only for coinpamonate same-sex relationships, but also for the notion that such relationships were intimate unions closely akin to different-sex marriages.

Further evidence of same-sex relationships may be found in Mesopotamian statutes, which have been preserved, escaping the fate of the lost Egyptian laws. None of Mesopotamia's early legal codes-the Laws of Urukagina (2375 B.C.), the Laws of Ur-Naminu (2100 B.C.), the Laws of Eshnunna (1750 B.C.), the Laws of Hammurabi (1726 B.C.), and the Hittite Laws (circa 800 B.C.)-prohibited or disapproved of saine-sex relationships, ${ }^{59}$ even though sex and marriage were otherwise heavily regulated. Indeed, the Hittite Laws can be read to suggest that same-sex inarriage was legally as well as culturally sanctioned in at least some parts of ancient Mesopotamia. Table I of the Hittite Laws regulated marriage, specifically the husband's payment of bride-price to the wife. ${ }^{60}$ Although it was assumed that this regulation apphed to the advantage of free Hittite citizens, special provisions in Table I afforded explicit legal authority for slaves to obtain brides in this way; otlierwise, slaves apparently could not inarry. For example, section 34 provided: "If a slave gives the brideprice to a woman and takes lier as his wife, no-one sliall [make him]

58 David M. Halperin, One Hundred Years of Homosexuality 81 (1990) (citations omitted).

59 Greenberg, supra note 47, at 124-25; see also The Ancient Near East: An Anthology of Texts and Pictures 133-67 (James B. Pritchard ed., 1958) (reproducing some of these statutes in English translations).

60 See Ephraim Neufeld, The Hittite Laws 8-11 (1951) (translating some of the Hittite Laws regulating marriage). 
surrender her." 61 By one reading, section 36 then provided that, "[I]f a slave gives the bride-price to a free youth and takes him to dwell in his household as spouse, no-one shall [make him] surrender him."62 For most of this century, there has been controversy over whether this is the correct reading of section $36 .{ }^{63}$ If the quoted reading were correct, a male slave with money (the bride-price) to pay for a male spouse could do so and expect that the transaction would be enforceable at law. And, of course, if a slave were allowed to do this, it would go without saying that a free Hittite citizen could do the same.

\section{Classical Greece and Pre-Christian Rome}

In contrast to the speculative evidence reported above for same-sex relationships (and possibly marriages) im Mesopotamia, there is stronger proof that classical Greek culture was keenly interested in and developed cultural norms to govern same-sex relationships. To illustrate, exemplars of both compamonate and transgenerational same-sex relationships may be found in Plato's Symposium, ${ }^{64}$ written in the fourth century B.C. Apparently the earhest known systematic treatise on the subject, the Symposium is a dialogue between Socrates and others in "the praise of Love,"65 with love and relationships between men its primary focus. The first speech praising love is that of Phaedrus, who champions transgenerational male-male relation-

61 Id. at 10.

62 This is my translation and understanding of the text, as well as the reading accepted by Boswell, supra note 46, at 20-21 \& n.39 (citing both concurring and dissenting authorities), who disagrees with the reading preferred by Neufeld: "If a slave gives the bride-price to a free youth and takes him to dwell in his household as husband [of his daughter], no-one shall surrender him." Neufeld, supra note 60, at 10-11 (also citing concurring and dissenting authorities). The bracketed portion is an interpolation by Neufeld, who admits as much. Id. at 151 . He also reports that most previous scholars had interpreted $\S 36$ as a state sanction for homosexual relations among slaves, and that "such a relationship among free men did not require any special legal provisions." Id. Boswell rejects Neufeld's speculations as a strained effort by a modern historian to read his own prejudices into another culture's text. Boswell, supra note 46, at 20-21. Boswell's reading, in turn, is rejected in Greenberg, supra note 47, at 125 n.3.

63 See Greenberg, supra note 47 , at 125 n.3.

64 Plato, Symposium, reprinted in On Hoinosexuality: Lysis, Phaedrus, and Symposium 103 (Benjamin Jowett trans., with selected retranslation, notes, and introduction by Eugene O'Connor, 1991).

65 Id. at 110 (line 177e). 
ships. ${ }^{66}$ Phaedrus cites as the ultimate in love and commitment the maxim that "[1]ove will make men dare to die for their beloved; and women as well as men." $67 \mathrm{He}$ goes on to provide as one example of this sacred commitment Alcestis' willingness to die for her husband Admetus, ${ }^{68}$ and as another Achilles' willingness to die for his lover Patroclus. ${ }^{69}$ By couplimg these examples, Phaedrus suggests that the husband-wife relationship and the Achilles-Patroclus relationship could be considered functionally similar, but were also formally different because the former was a marriage whereas the latter was not, quite.

Pausamas next spoke, delivermg an impassioned defense of compamionate same-sex relationships:

Those who are inspired by this love turn to the male, and delight in him who is the more valiant and intelligent nature; any one may recognize the pure enthusiasts in the very character of their attachments. For they love not boys, but intelligent beings whose reason is beginning to be developed, inuch about the time at which their beards begin to grow. And in clooosing thein as coinpanions, they inean to be faithful to thein, and to pass tlieir whole life with them, and be with thein $\ldots{ }^{70}$

Later Pausanias praises the man who loves witl1 "tlie love of the noble mind, whicl is $\mathrm{m}$ union witl the unchangeable, is everlasting."71 Like Phaedrus, Pausanias seems to be assuming a society where such love between men is valuable and lastimg, but not necessarily a marriage.

The fourtli speecl1, presented by Aristoplianes, is the most imteresting because it sets fortli a theory not only of love but of the origins of liunian sexual biology and desire. ${ }^{72}$ According to Aristoplianes, liunians were originally rotund giants witl eiglit appendages (four arms, four legs) and two sets of sexual organs-eitler two male geuitalia (male giants), or two female genitalia (female giants), or one

66 See id. ("For I know not any greater blessing to a young man beginning life than a virtuous lover, or to the lover than a beloved youth.") (line 178c). This is also a theme of Plato's Phaedrus, reprinted in On Homosexuality, supra note 64, at 43.

67 Plato, supra note 64, at 111 (line 179b).

68 Id. (lines $179 \mathrm{~b}-\mathrm{c}$ ).

69 Id. at 112 (lines $179 \mathrm{e}-80 \mathrm{~b}$ ).

70 Id. at 113-14 (lines 181c-d) (footnote omitted).

71 Id. at 116 (line 183e).

72 See id. at 121-26 (limes 189c-93e). 
female and one male (androgynous giants). ${ }^{73}$ Vexed by the mischief fomented by these giants, Zeus cut them all im half, Apollo later performing reconstructive surgery on the halved, formerly gigantic humans. The divine cleaving yielded three types of humans, those originally from the female giants, those from the male giants, and those from the androgynous giants. ${ }^{74}$ Sexuality is each human's effort to find and mate with his or her literal "other half."75 Aristophanes concludes his speech with a classic statement of companionate love:

[W] hen one of them [boys who have reached manhood] finds his other half, whether he be a lover of youth or a lover of another sort, the pair are lost in an amazement of love and friendship and imtimacy, and one will not be out of the other's sight, as I may say, even for a moment: these are they who pass their hives with one another . . . ${ }^{76}$

Although Plato is the first systematic thinker about sex whose work has survived, his views are not transparent, and the Symposium might be imterpreted differently in light of Plato's other essays, especially the Laws and the Republic. The Laws reveals an ambivalence about same-sex erotic attraction, and the Republic valorizes an idealized form of love over a physical form. In the Symposium itself, the speech of Diotima asserts that love starts with the love of beautiful male bodies but matures into love of abstraction, especially beauty. ${ }^{77}$ Drawing froin these other works, Gregory Vlastos interprets the Symposium to reflect Plato's philosophical attraction to the procreative

73 Id. at 121-22 (lines 189d-90b).

74 Id. at 122-24 (lines 190c-92).

75 As Aristophanes put it:

[S]o ancient is the desire of one another which is implanted in us, reuniting our original nature, making one of two, and healing the state of man. Each of us when separated is but the indenture of a man, having one side only like a flat fish, and he is always looking for his other half. Men who are a section of that double nature which was once called androgynous are lascivious; adulterers are generally of this breed, and also adulterous and lascivious women: the women who are a section of the woman don't care for men, but have female attachments; the female companions are of this sort. But the men who are a section of the male follow the male, and while they are young, being a piece of the man, they hang about him and embrace him, and they are themselves the best of boys and youths, because they have the most manly nature.

Id. at 123-24 (limes 191d-92) (footnotes omitted).

76 Id. at 124 (lines 192b-c).

77 See Gregory Vlastos, Platonic Studies 40-41 (1981). 
ideals in love, clearly heteroerotic, and not just the homoerotic dimensions. ${ }^{78}$

Historians of classical Greece and its romantic institutions consider the Symposium to reflect the ambivalent but accepting attitudes toward same-sex relationships prevailing in at least some of the Greek city-states. No law prohibited same-sex relationships, and, indeed, they were institutionahized for free male citizens, who were expected to court and have a relationship with a boy in their early adulthood. Although inost historians have not ventured to consider these transgenerational umions to be inarriages, they have asserted that they were often the functional equivalents of legalized marriages. Kenneth Dover, the leading historian of Greek sexual mores, argues strongly for "common ingredients" between different-sex marriages and ancient Greek saine-sex relationships, citing a formal "courtship" by the dominant party (the husband/man) toward the receptive party (the wife/boy) and the expectation that the receptive party would respond to advances coyly, that is, not embracing them but not otherwise discouraging the suitor either. ${ }^{79}$ As is often the case in traditional heterosexual marriages, the family became involved in the receptive party's decision whether to accept the dominant party's advances. ${ }^{80}$ Finally, both types of relationships met with social disapproval if sexual relations occurred outside of the accepted courtshipto-wedding-vow relationship. ${ }^{81}$ Dover also describes ritualized samesex transgenerational courtship in Crete, which other historians have characterized as same-sex "marriages." 82 Eva Cantarella believes that soine of the lesbian relationships arising out of female collectives (thiasoi) were "imitiation marriages," institutionally sinilar to male same-sex relationships described by Dover. ${ }^{83}$

The mythical Achilles-Patroclus relationship also shows how the ancient Greeks considered same-sex unions to be not so distant from their different-sex inarriage counterparts. Halperin, for example,

78 See id. at 40-42; see also Eva Cantarella, Bisexuality in the Ancient World 61-63 (Cormac Ó Cuilleanáin trans., 1992) (describing the procreative nature of sexual pleasure in Plato's Laws).

79 See K.J. Dover, Greek Homosexuality 89-91 (1978).

80 Id. at $89-90$.

81 Id. at 90.

82 See id. at 189-90; Boswell, supra note 46, at 54 (citing L.R. de Pogey-Castries, Historie de L'Amour Grec dans L'Antiquité $42-46$ (1930)).

83 See Cantarella, supra note 78 , at $81-83$. 
finds the Achilles-Patroclus relationship constructed out of the same notions of kinship and sexual imagery that were discussed earhier with respect to the Gilgamesh-Enkidu relationship:

Patroclus performs many of the functions for Achilles that a wife or female dependent normally performs in the Homeric world: for example, he places food before Achilles when the two of them are dining alone and, when they are entertaining guests, it is Patroclus who distributes the bread ... ; Patroclus also makes up a spare bed for Phoenix when Achilles gives him the nod. . . . The conjugal associations, however, work reciprocally: at Patroclus's funeral, Achilles, as chief mourner, cradles the head of his dead comrade, the same gesture that is performed by [Queen] Andromache at Hector's funeral. So each, in a sense, is wife to each. ${ }^{84}$

Halperin argues that the Achilles-Patroclus relationship is something more than transgenerational boy-love, because it is not clear who in the relationship is the boy and who is the man. ${ }^{85}$ He concludes that same-sex Greek relationships were often more like modern companionate marriages than the Greeks' own institution of different-sex marriage, in which the husband and wife had little emotional affinity and the husband liad great freedom to engage in outside sexual liaisons. ${ }^{86}$

The consensus among modern historians is that republican Rome, like classical Greece, was tolerant of same-sex relationships. ${ }^{87}$ Moreover, the Romans may have accorded some same-sex uinons the legal or cultural status of marriages. To take one early example, Cicero, the great Roman lawyer and orator, persuaded Curio the Elder to honor the debts that Curio's son liad incurred on belialf of Antornus, to whom the son was, in Cicero's words, "united in a stable and permanent marriage, just as if lie had given him a matron's stola." ${ }^{88}$ Cic-

84 Halperin, supra note 58 , at 84.

85 Id. at 86.

86 Id. at $85-87$.

87 Contrary to some earlier beliefs, it now appears that the laws of republican Rome did not prolibit same-sex relationships. See Cantarella, supra note 78, at 106-14; Saara Lilja, Homosexuality in Republican and Augustan Rome 130-31 (1983); Paul Veyne, Homosexuality in ancient Rome, in Western Sexuality: Practice and Precept in Past and Present Times (Phillipe Ariès \& André Béjin eds., Antliony Foster trans., 1985).

88 Boswell, supra note 46, at 69 (quoting Cicero's Philippic). In the original, tlie quotation reads, "Te a meretricio quaestu abduxit et, tamquam stolam dedisset, in matrimonio stabili et certo collocavit." Id. at 69 n.37. As Boswell points out, the stola was garb distinctively reserved for a married Roman woman. Id. 
ero's legalistic advice suggests that same-sex relationships were not only socially accepted among at least some segments of Roman society, but that tliey also potentially carried with them legal obligations and consequences, and lence were marriages as I am using the term.

Records describing Roman social customs during the imperial period survive in far greater number, at least in part because many, if not most, of the emperors enjoyed well-documented relationshipssome of them legally sanctioned marriages-with otlier men. The evidence suggests that during the same general time frame wlien companionate long-term marriages were being institutionalized for different-sex couples, ${ }^{89}$ they were likewise becoming more common for same-sex couples, who were entering into relationships akin to those discussed in Plato's Symposium. Medieval historian John Boswell describes the period:

By the time of the early Empire the stereotyped roles of [sexually active] "lover" and [sexually passive] "beloved" no longer seem to be the only model for homosexual lovers, and even emperors abandoned traditional sexual roles for more reciprocal erotic relations. Many homosexual relationships were permanent and exclusive. Among the lower classes informal unions like that of Giton and Encolpius may have predommated, but marriages between males or between females were legal and familiar among the upper classes. ... [B]y the time of the early Empire references to gay marriages are commonplace. The biographer of Elagabalus maintains that after the emperor's niarriage to an athlete from Smyrna, any male who wished to advance at the imperial court either had to have a husband or pretend that he did. Martial and Juvenal both mention public ceremonies involving the families, dowries, and legal niceties. It is not clear that only aristocrats were involved: a cornet player is mentioned by Juvenal. Martial points out that both men involved in one ceremony were thoroughly masculine ("The bearded Callistratus married the rugged Afer") and that the marriage took place under the saine law that regulated marriage between men and women.

Nero married two men in succession, both in public ceremonies with the ritual appropriate to legal marriage. At least one of these unions was recoguized by Greeks and Romans, and the spouse was accorded the honors of an enipress. . . . One of the men, Sporus, accompanied Nero to public functions, where the emperor would

${ }^{89}$ See 3 Michel Foucault, The History of Sexuality 72-80 (Robert Hurley trans., Pantheon Books 1986) (1984). 
embrace him affectionately. He remained with Nero throughout his reign and stood by him as he died. ${ }^{90}$

Boswell also cites examples from Roman writers describing marriages between two women, ${ }^{91}$ though female same-sex unions were apparently much less common because women had fewer economic opportumities, and less social and legal freedom than men.

Same-sex unions were noted in popular Roman culture and literature as well. The novel Babylonica, an early version of the pulp romance, had a subplot mvolving the passion of Egypt's Queen Berenice for the beautiful Mesopotamia, who was snatched from her. After one of the Queen's servants rescued Mesopotamia from her abductors, "Beremice married Mesopotamia, and there was war between [the abductor] and Berenice on her account." "92 Of even greater renown, the Emperor Hadrian's love for Antinous attamed the status of legend, acclaimed for generations in sculpture, architecture, painting, coims, and literature. ${ }^{93}$ Boswell suggests that the popularity of Hadrian and Antinous as a couple,

may have been due in some part to the prevalence of same-sex couples in popular romantic literature of the time. Everywhere in the fiction of the Empire-from lyric poetry to popular novels-gay couples and their love appear on a completely equal footing with their heterosexual counterparts. ${ }^{94}$

\section{Christian Rome and the Middle Ages}

The late Roman Empire grew less tolerant of homosexual unions than either the Republic or the earlier Empire had been, and in 342 A.D. adopted a statute that seemingly-but perhaps facetiously-proclaimed that those who entered into same-sex marriages would be subjected to "exquisite punishment." While the statute reinforces

\footnotetext{
90 Boswell, supra note 46 , at $81-82$ (citations and footnotes omitted).

91 See id. at $82-83$.

92 Id. at 84 (quoting Photius' Bibliotheca).

${ }^{33}$ See Royston Lambert, Beloved and God: The Story of Hadrian and Antinous (1984); Marguerite Yourcenar, Hadrian's Memoirs (1957).

94 Boswell, supra note 46, at 85-86. Following Cantarella, supra note 78, at $155-56$, I would read Boswell's claims conservatively.

95 The statute reads:

When a man "marries" in the manner of a woman, a "woman" about to renounce men, what does he wish, when sex has lost its significance; when the crime is one which it is not profitable to know; when Venus is changed into another form; when love is sought
} 
the impression that same-sex marriages were not uncommon in the Roman Empire, it also evidences an anxiety about same-sex unions that surely predated the fourth century. At the end of the second century, for example, Plutarch's Moralia imcluded a dialogue filled with invective both for and agamst same-sex relationships, suggesting that their propriety was a matter of some controversy. A subsequent anonymous dialogue entitled Affairs of the Heart ${ }^{96}$ was fairly sympathetic to same-sex relationships but sharply distinguished them from marriage. ${ }^{97}$

The late philosopher-historian Michel Foucault suggests that imperial Roine's anxiety about same-sex relations was related to the institutionahzation of compamionate marriage, during which period procreation became intertwined with sexual partnership. ${ }^{98}$ There is probably a connection between the statute of 342 A.D.'s anti-homosexual tone and the increasing influence of Christiamity during the late Empire. ${ }^{99}$ Partly inspired by its Judaic heritage, the early Christian tradition advocated companionate different-sex marriage, which served procreative purposes, and was ambivalent about same-sex relationships. ${ }^{100}$ The early church fathers-most notably Clement,

and not found? We order the statutes to arise, the laws to be armed with an avenging sword, that those infamous persons who are now, or who hereafter may be, guilty may be subjected to exquisite punishment.

Grecnberg, supra note 47, at 229 (translating the Theodosian Code 9.vii.3 (Pharr, 1952:23132)). Cantarella argues that this statute only penalized "passive" homosexual behavior and that nubere should be translated as "couples" and not "marries." See Cantarella, supra note 78, at 175-76.

96 See Foucault, supra note 89, at 211-27 (discussing Affairs of the Heart).

97 Boswell sets forth the judgment at the end of the dialectic:

"Marriage is a boon and a blessing to men when it meets with good fortune, while the love of boys, that pays court to the hallowed dues of friendship, I consider to be the privilege only of philosophy. Therefore all men shonld marry, but let only the wise be permitted to love boys, for perfect virtue grows least of all among women."

Boswell, supra note 46, at 127 (quoting Affairs of the Heart).

98 See Foucault, supra note 89, at 72-80; see also Peter Brown, The Body and Society: Men, Women and Sexual Renunciation in Early Christianity 16 (1988) (describing the emphasis on procreation).

99 The Emperor Diocletion persecuted the Christians in the late third century. When he died in 306 A.D., the Empire plunged into one of its by then frequent civil wars. Constantine I reurited the Empire under his reigu from the period 324-37 A.D. Because Constantine had converted to Christianity in 312 , its official influence was assured during his reign and continued in some degree or another until Rome fell in 476.

100 See generally Brown, supra note 98 (tracing early Christian attitudes toward differentsex and same-sex relationships). 
Jerome, Origen, and Augustine-developed a philosophy of sexual abstinency that problematized any sexual activity done for pleasure itself. But other, non-Christian traditions im Roman society-Stoicism, Neo-Platonism, Manicheanism-similarly urged that "intercourse was supposed to take place only so as to produce children. The couple must not make love for the sake of pleasure alone."101 The ascetic movements in the later Empire were at best ambivalent about same-sex intimacy. Some Manicheans, for example, criticized same-sex intimacy for not serving to procreate, while others found it acceptable because it "did not partake of the false aura of sanctity which marital sexuality used to seduce the unwary."102

The collapsing Roman Empire grew increasingly inhospitable to same-sex unions, and after Rome's fall state attitudes toward such unions deteriorated dramatically. In the surviving Eastern Empire, the Justinian Code of 533 A.D. fiatly outlawed same-sex intimacy, placing it in the saine category as divorce and adultery ${ }^{103}$-all of which violated the Christian ideal of companionate different-sex marriage. ${ }^{104}$ In what remained of the Western Einpire, the Visigoth state in Spain crimnialized same-sex intimacy around 650 A.D., ${ }^{105}$ though inost of the other Germanic states showed little interest in either advocating or decrying same-sex relationships. ${ }^{106}$ At first glance, it would appear that the same-sex unions of the earlier Roman Empire all but died out during the early Middle Ages, when different-sex companionate marriage and a philosophy of sexual abstinence became the norm. A closer look reveals the story to be a more complicated one.

The complication owes much to the Roman Catholic and Greek Orthodox Churches' conflicting responses to same-sex unions: their abstract notions of the propriety of saine-sex marriage differed niark-

101 Id. at 21; see Boswell, supra note 46, at 128-31.

102 Boswell, supra note 46, at 129.

103 Cantarella, supra note 78 , at $181-86$.

104 Id. at 209-10.

105 See The Visigothic Code (Samuel P. Scott trans. \& ed., 1910) (translating the edict in Title V, $\S$ VI of the Code).

106 See Boswell, supra note 46, at 176-79. Boswell speculates that the Germanic tribes that invaded the Western Empire tolerated homosexual activities in at least some circumstances, id. at 183-85, and that some of the tribe members may have enjoyed a transgenderal role similar to that of Native American berdaches, "and such relationships may have been institutionalized as 'marriages' among them." Id. at 184. 
edly froin their actual response when confronted by same-sex intimacy. During the early and high Middle Ages, the Church was spiritually critical of same-sex imtimacy because it could not result in procreation and constituted sex outside of the then-estabhshed ideal of compamionate marriage. Paradoxically, the Church was in soine respects tolerant of same-sex unions in practice, especially those within its own clergy. Homoerotic feelings repeatedly arose between teachers and students, clerics and their fellows, and priests and acolytes, yearnings which are documented in a proliferation of love letters, poeins, and stories originating from the early and high Middle Ages. ${ }^{107}$

More importantly, in the early Middle Ages the Church developed institutions-memorialized in liturgies that were mcluded in the Churcli's formal collections-that combined the Church's spiritual coinmitinent to coinpamionate relationships witl its members' desire to bond with people of the same sex. Existing scholarship docuinents the existence of Roman Cathohic and Greek Orthodox rituals of "brotlier-making," "enfraternization," and "spiritual brotherhoods." 108 Cereinonies creating these brotlierhoods were sometimes performed for male missionaries before they embarked on their imssions, as well as for other males who wished to formalize their friendships. According to Cliurch archives, these early ceremonies were structured as follows:

- The couple stand in front of the lectern, on which are placed the Gospel and a cross. The older of the brothers stands to the right.

107 See id. at 186-94. For example, the priest Alcuin (the most important intellectual figure in the court of Charlemagne) wrote a bishop:

I think of your love and friendship with such sweet memories, reverend bishop, that I long for that lovely time when I may be able to clutch the neck of your sweetness with the fingers of my desires. Alas, if only it were granted to me, as it was to Habakkuk, to be transported to you, how would I sink into your einbraces, ... . how would I cover, with tightly pressed lips, not only your eyes, ears, and mouth but also your every finger and your toes, not once but many a time.

Id. at 190 (quoting and translating the letter). Most of the letters and poems are not so openly erotic as this.

108 See, e.g., Pavel Florenskij, La Colonna e il Fondamento della Verita 521-25 (Pietro Modesto trans. \& Elemire Zolla intro., 1974) (describing the ceremony and its liturgy). The Reverend Alexei Michalenko originally brought this material to my attention and has also supplied me with copies of Greek Orthodox liturgies, both in the original Greek and translated into Latin. The translations in text are my renderings of the Latin, checked against those provided by Reverend Michalenko. 
- The ceremony starts off with prayers and litanies celebrating earlier examples of same-sex couples or friends in the early Cliurcli.

- The couple is girded witl a single belt, signifying their union as one, and they place their hands on the Gospel and receive lit candles.

- The priest reads from one of Paul's epistles (1st Corinthians 12:27) and the Gospel (John 17: 18-16), followed by more prayers and litanies.

- The assembled are led in the Lord's Prayer, followed by Holy Commumon, the Eucliarist, for the couple.

- The priest leads the couple around the lectern, each lolding the hand of the other, while the assembled sing a liymn.

- The couple excliange a kiss, and the service concludes witl the singing of Psalm 132:1 ("Beliold low good and sweet it is for brotliers to live as one."). ${ }^{109}$

Significantly, this early brotherhood liturgy was acted out in a cereinony that was virtually identical to the liturgy later developed by the Church for different-sex inarriages.

The main difference between the brotlierhood liturgy and the one originally used to wed different-sex couples was that the former emphasized the coinpanionate ${ }^{10}$ rather than the procreative ${ }^{111}$ nature of the relationship. Hence, ratlier than orating on procreation, one version of the enfraternization hiturgy read:

O Almiglity Lord, you liave given to man to be made from the first in Your Image and Likeness by the gift of immortal life. You liave willed to bind as brothers not only by nature but by bonds of the spirit Your most celebrated Apostles Peter, the Chief of them all, and Andrew; James and John the Sons of Zebedee; Philip and Batlolomew. You made as very brotliers Your Holy Martyrs Sergius and Bacclius, Cosmas and Damien, Cyrus and John. Bless Your Servants umited also that, not bound by nature, (they be) jomed witlı bonds of love. Grant tliem a love mutual and witlout offense and a brotlierhood upset by naught of liatred all the days of their lives, through the might of Your All-Holy Spirit and tlirough the imtersession of our All-Holy spotless ever-Virgin Lady . . . ${ }^{112}$

\footnotetext{
109 Florenskij, supra note 108, at 523-24.

110 See Psalms 132 (King James).

111 See Psalms 127 (King James).

112 Ritualae Graecorum Complectens Ritus et Ordines Divinae Liturgiae 707 (R.P. Jacobi Goar ed. \& trans., reprinted in 1960). A complete translation of another version of the liturgy is appended to this Article.
} 
The precise significance of these enfraternization liturgies remains to be determined. They may have been little more than send-offs for missionaries. In light of the early Cliurch's ascetic approach to sexuality, it seems doubtful that these ceremonies contemplated sexual unions. But recent research by Professor Boswell argues that these ceremomies represented a niore general acceptance of same-sex unions by the early Cliurcli.

In 1989, Boswell claimed in print that:

Gay clerics apparently took part in homosexual marriage cerenionies, which were widely known in the Catholic world from the fifth century on. Such cerenionies were performed in Catholic churches by priests and either established what the community regarded as marriages, or commemorated special friendships, in both cases in devoutly Christian terms. ${ }^{113}$

Boswell's claim was based upon infornation acquired while researcliing medieval Cliristian liturgical collections, evidence that will be revealed in a fortlicoming book. ${ }^{114}$ Boswell has reportedly uncovered manuscript versions of Cliristian sanie-sex marriage liturgies taken from collections found in libraries and ecclesiastical collections tlirougliout Europe. References to same-sex marriage ceremonies were discovered in legal texts from the fourth through the sixth centuries, as were references to the actual perforniance of such ceremonies occurring in the fiftli through the nineteenth centuries. Boswell distinguishes between the enfraternization liturgies described above, of which scholars have known and written for some time, and tliese newly-discovered marriage liturgies, which he believes to confirn the existence of genuine, Cliurch-sanctioned same-sex marriages. ${ }^{115}$

113 John Boswell, Homosexuality and Religious Life: A Historical Approach, in Homosexuality in the Priesthood and the Religious Life 3, 11 (Jeannine Gramick ed., 1989).

114 Boswell, supra note 3. In this work, Boswell will describe same-sex companionate marriage liturgies in the Christian Church from the fifth through the nineteenth centuries. My description of some of the book's findings is based upon his 1989 article, see Boswell, supra note 113; a videotaped speech by Professor Boswell on the liturgies entitled " 1500 Years of Blessing Gay and Lesbian Relationships: It's Nothing New to the Church" [hereinafter " 1500 Years of Blessing"] (available from the Washington chapter of Integrity, a gay and lesbian Episcopal group); and correspondence with Professor Boswell.

115 Boswell claims that one can distinguish the two readily enough, based upon the precise wording used in the liturgies, their titles, and their placement in liturgical collections and indices. See Boswell, 1500 Years of Blessing, supra note 114. 
If Boswell's claims are borne out, they would reconcile the old Roman tradition of same-sex marriages still popular when Christianity was spreading throughout the Empire and the Church's emphasis on coinpanionate marriage as the model for Christian social life and its spiritualization of the mstitution of marriage. As to the last poimt, the Roman Catholic Cliurcli did not make different-sex marriage sacramental, celebratimg Holy Commumion and performing the ceremony at the Church altar, until the thirteenth century, whereas Boswell maintains that same-sex marriages were sacramental in the early Middle Ages. When his long-awaited book is publislied, Boswell's evidence and thesis will spark further research efforts.

\section{B. Same-Sex Unions in Non-Western Cultures}

There is very strong evidence demonstratimg the existence of samesex unions, including legally recognized marriages, im Native American, African, and Asian cultures, evidence which is especially striking prior to those cultures' domination by Western Europe. As before, my sources mclude traditional historical records, such as contemporary accounts, artifacts, mytlis, and stories, though the best evidence tends to be the work of social anthropologists and ethnographers, wlio, through their fieldwork in non-Western cultures, have been able to retrieve much of these cultures' pre-Western traditions and institutions. Among the most frequently recurring of these mstitutions is same-sex marriage.

\section{Native American Cultures}

Although few written records of pre-Columbian Native American cultures are accessible to us, we do have the benefit of listories describing those cultures written by Spanisli explorers, missionaries, and bureaucrats. ${ }^{116}$ These sources provide early accounts of same-sex umions in the Americas. ${ }^{17}$ For example, Francisco López de

116 Most of the sources I shall refer to in the text are collected and translated in Francisco Guerra, The Pre-Columbian Mind (1971); see also Jonathan N. Katz, Gay Ainerican History 281-334 (rev. ed. 1992) (collecting original docuinents on the history of "Native Americans/ Gay Americans: 1528-1976").

117 In the quotations that follow, the Spanish observers refer to same-sex unious in marital terminology. This may reflect their projection of Western norms onto Native Americans. The more recent work of social anthropologists, however, gives me greater confidence that these relationships were indeed inarriages. 
Gómara's History of the Indies (1552), proclaimed that " 'the men marry other men who are impotent or castrated and go around like women, perform their duties and are used as such and who caunot carry or use the bow." "118 Alvar Cabeza de Vaca also witnessed unions between same-sex couples, stating in Narrative of the Expeditions and Shipwrecks of Cabeza de Vaca (1542) that he "saw a nian married to another man." "119 Juan de Torqueniada, in the Monarchia Indiana (1615), described a common custoni whereby

"parents [gave] a boy to their young son, to have him for a woman and to use him as a woman; from that also began the law that if anyone approached the boy, they were ordered to pay for it, punishing them with the same penalties as those breaking the condition of a marriage." 120

Same-sex unions between wonien were also reported. Pedro de Magãlhaes' The Histories of Brazil (1576) describes Native American women in northeastern Brazil who "give up all the duties of wonien and initate men, and follow nren's pursuits as if they were not women. ... [E]ach has a woman to serve her, to whoni she says she is married, and they treat each other and speak with each other as man and wife." 121

What these (and other) accounts describe is the berdache tradition in the Americas, which was institutionalized in the Indies and throughout what is now the United States, as well as in the Aztec, Mayan, and Incan civilizations. The Native American berdache is a person-niale or female-who deviates from his or her traditional gender role, taking on some of the characteristics and perceived responsibilities of the opposite sex. The berdache does not, however, cross gender lines so much as nix then. Indeed, niany Native American cultures considered berdaches to be a third sex. ${ }^{122}$ Most important for the present study, berdaches (like We'wha) niarried

118 Guerra, supra note 116, at 85 (quoting Francisco López de Gómara, History of the Indies (1552)).

119 Id. at 67 (quoting Alvar Cabeza de Vaca, Narrative of the Expeditions and Shipwrecks of Cabeza de Vaca (1542)).

120 Id. at 173 (quoting 1 Juan de Torquemada, Monarchia Indiana 422 (1615)).

1212 Pedro de Magälhaes, The Histories of Brazil 88-89 (John B. Stetson, Jr. trans., 1922) (1576).

122 See Charles Callender \& Lee M. Kochems, Men and Not-Men: Male Gender-Mixing Statuses and Homosexuality, in The Many Faces of Homosexuality: Anthropological Approaches to Homosexual Behavior 165 (Evelyn Blackwood ed., 1986). 
individuals of the same sex, and those transgenderal marriages were well recognized by Native American laws and cultures. ${ }^{123}$

Outsiders' depictions of the Native American berdache have often been colored by their anti-homosexual attitudes. The accounts of Spanish authors such as those quoted above usually expressed shock, invoking Native American same-sex unions as evidence of these cultures' barbarism, which they sought to correct. Until the twentieth century, accounts by Western anthropologists suppressed the tradition. ${ }^{124}$ The first detailed academic study focusing on Native American same-sex unions was George Devereux's article on the Mohave berdaches. ${ }^{125}$ Devereux reported that gender-crossing, hoinosexual inen (alyha) and woinen (hwame) had long been tolerated by the Mohave, and that their same-sex marriages were institutionalized and socially accepted. Thus, under tribal custom and law alyha married (and divorced) men, ${ }^{126}$ and hwame inarried (and divorced) women. ${ }^{127}$

Ethnographers and anthropologists studying the culture and evolution of various Native American tribes throughout this century discovered similar berdache institutions. ${ }^{128}$ Drawing from earher

123 Id. at $172-75$.

124 E.g., Alfred L. Kroeber, The Arapaho, 18 Bull. Am. Museum Nat. Hist. 1, 19 (1902) (describing berdaches "Inarried to men").

125 See George Devereux, Institutionalized Homosexuality of the Mohave Indians, 9 Hum. Biology 498 (1937).

126 The courtship process was nsually a brief one, in which the suitor would flirt with the alyha. "At dances even boys who had no intention of marrying an alyha played around with thein, as though they were flirtatious women. 'In the end soine of them made up their minds to become the husbands of an alyha.' "Id. at 513. There were a number of advantages for men who married an alyha rather than a woman. For example, "[o]nce they were married the alyha made exceptionally industrious wives." Id. "Divorcing an alyha was not an easy matter," however, because they were strong and "'might beat you up." "Id. at 514.

127 "The hwame got their wives usually at dances or by visiting girls and married women during the day.... The hwame were excellent providers and took pride in dressing up their wives. . . Hwame were divorced by their wives more often than they divorced them." Id. at 515.

128 In addition to those discussed in text, leading monographs on Native American berdaches include Charles Callender \& Lee M. Kochems, The North American Berdache, 24 Current Anthropology 443 (1983); Donald G. Forgey, The Institution of Berdache Among the North American Plains Indians, 11 J. Sex Res. 1 (1975); W.W. Hill, Note on the Pima Berdache, 40 Am. Anthropologist 338 (1938); W.W. Hill, The Status of the Hernnaphrodite and Transvestite in Navajo Culture, 37 Am. Anthropologist 273 (1935); Nancy O. Lurie, Winnebago Berdache, 55 Am. Anthropologist 708 (1953); Elsie C. Parsons, The Zuni La'Mana, 18 Am. Anthropologist 521 (1916); Matilda C. Stevenson, The Zuni Indians, in The Twenty-Third Ann. Rep. Bureau Am. Ethnology 3 (1904); James S. Thayer, The Berdache of the Northern Plains, 36 J. Anthropological Res. 287 (1980); Harriet Whitehead, The Bow and 
accounts as well as his own fieldwork, Walter Williams' The Spirit and the Flesh synthesizes existing scholarship probing the Native American berdache tradition. ${ }^{129}$ On the basis of these accounts, Wilhams concludes that berdaches have been an accepted and in fact valued part of culture and law in a large inajority of Native American tribes. ${ }^{130}$ Most academic attention has been focused on male berdaches, like We'wha, who frequently becaine revered leaders in their communities. Often, a inale child is consciously raised to be a berdache, who assumes a special role in the community, inediating between the spiritual and physical worlds. ${ }^{131}$ Marriages between inen and inale berdaches were widespread ainong Native American cultures. $^{132}$ As a general inatter, same-sex inarriages tended to conform to the traditional Native American inarriage paradigm, in which labor was divided between the wife, who kept house, and the husband, who hunted and directed the household. ${ }^{133}$ The men who married inale berdaches were usually attracted to woinen as well as to inen and were not themselves considered berdaches. Many such men preferred berdache wives for economic advantages, as berdaches not only would do the housework, but would help with hunting and other traditionally male activities as well. Others beheved that marrying a berdache guaranteed greater marital stability, while still other con-

the Burden Strap: A New Look at Institutionalized Homosexuality in Native North America, in Sexual Meanings, supra note 43 , at 80 .

129 See Walter L. Williams, The Spirit and the Flesh: Sexual Diversity in American Indian Culture (1986).

130 See id. at $41-43$.

131 Id. at 44-57.

132 "In a massive survey of northern California Indian cultures conducted in the 1930s, all but one of the groups who recognized a berdache status also recognized marriage to a 'normal man." 'Id. at 110 (citing 20 Erminie W. Voegelin, Culture Element Distributions 134-35 (1942)).

133 In a marriage between a man and a berdache, the berdache supplies women's work and a network of kin, like any other wife. ... A berdache wife offered the same econounic advantages of any other polygymous marriage. While it is true that a berdache cannot reproduce, many of the reports of such marriages mention that the husband already had children, either through a previous marriage or by taking a berdache as a second or third wife. But with adoption being so commonly accepted, children may even be gamed by the berdache. Thus, the same advantages of heterosexual inarriage also accrue to the man who marries a berdache.

Id. at 112 . 
ventional men pursued male berdaches on the basis of simple sexual attraction. ${ }^{134}$

Although they have received less academic attention, female berdaches comprised an equally important cultural imstitution in most Native American communities. Like her male counterpart, the feinale berdache assumed inany of the responsibilities traditionally performed by the opposite sex, mcluding hunting and heading a household. Additionally, she would commonly marry another woman. ${ }^{135}$ Evelyn Blackwood's detailed study ${ }^{136}$ shows that female berdaches and woman-woman marriages were integral to women's status in most Native American cultures:

Native American beliefs about sexuality are reflected in the marriage system. Theorists sucl as Gayle Rubin have implicated marriage as one of the mechanisms that enforce and define women's sexuality. According to Rubin, the division of labor "can . . . be seen as a taboo against sexual arrangements otler than those containing at least one man and one woman, thereby enjoining lieterosexual inarriage." Yet in certain Native American tribes other sexual behavior, both heterosexual and lomosexual, was available and permissible within and outside of marriage. Homosexual behavior occurred in contexts within which neitler individual was cross-gender nor were sucl individuals seen as expressing cross-gender behavior. . . . Furthermore, througli the cross-gender role, women could marry one another. ...

Native American ideology disassociated sexual behavior from concepts of inale and feinale gender roles and was not concerned witl the identity of the sexual partner. The status of the cross-gender female's partner is telling in this respect. She was always a traditional female; that is, two cross-gender females did not marry. Thus, a woman could follow the traditional female gender role, yet inarry and make

134 Id. at 114-15.

135 Thus, Williams says:

What about the wives of the amazon? Woman Chief, like the other amazons, evidently had no difficulty finding women to marry. ... .

With the exception of the amazon, women involved in a relationship with another female did not see themselves as a separate minority or a special category of person, or indeed as different in any inportant way from other women. Yet, they were involved in loving and sexual relationships with their female mates. If their marriage to an amazon ended, then they could easily marry heterosexually ....

Id. at 246-47.

136 See Evelyn Blackwood, Sexuality and Gender in Certain Native American Tribes: The Case of Cross-Gender Females, 10 Signs 27 (1984). 
love with another woman without bemg stigmatized by such behavior. ${ }^{137}$

Although Blackwood-like other scholars who have made similar observations ${ }^{138}$ - does not claim that Native American culture never imposed roles subordinating women, she argues that the ability to enter into same-sex marriages expanded women's range of options in an important way.

\section{African Cultures}

African cultures offer a particularly imteresting variety of same-sex unions, including transgenerational ones (typically man-boy relationships) and transgenderal unions similar to the Native American berdache tradition. African cultures also offer a variant of transgenderal and/or transgenerational union not encountered in the West or in Native American culture-the tradition of feniale-husbands, or woinan-niarriage. Recall Ifeyinwa Olinke, discussed in the Introduction of this Article.

\section{a. Transgenerational Unions (Boy Wives and Mummy-Daughter Relationships)}

Early scholarly works on transgenerational unions focused on those relationships cultivated aniong men. Most prominently, anthropologist E.E. Evans-Pritchard documented the institution of "boy wives" for military men among the Azande in what is now Sudan. ${ }^{139}$ According to Evans-Pritchard, the Azande considered the relationship a "niarriage" both legally and culturally:

I have pointedly used the terms "wife," "husband," and "marriage," for, as the texts will make clear, the relationship was, for so long as it lasted, a legal union on the nodel of a normal marriage. The warrior paid bridewealth (some five spears or more) to the parents of his boy and performed services for them as he would have done had he married their daughter; if he proved to be a good son-in-law they might

137 Id. at 35 (footnotes omitted).

138 See Judy Grahn, Another Mother Tongue: Gay Words, Gay Worlds 49-72 (1984); Paula G. Allen, Lesbians in American Indian Cultures, 3 Conditions 67 (1981); Beatrice Medicine, "Warrior Women"-Sex Role Alternatives for Plains Indian Women, in The Hidden Half: Studies of Plains Indian Women 267 (Patricia Albers \& Beatrice Medicine eds., 1983).

139 See E.E. Evans-Pritchard, Sexual Inversion Among the Azande, 72 Am. Anthropologist 1428-34 (1970). 
later replace the son by a daughter. Also, if another man had relations with his boy he could, I was told, sue him at court for adultery. .. . A boy was addressed by his lover as diare "my wife," and the boy addressed him as kumbami "my husband." . . . The boys performed many of the smaller services a woman performs daily for her husband, such as gathering leaves for his ablutions, gathering leaves for his bed, [and] drawing water and breaking off firewood for him .... With regard to the sexual side, at night the boy slept with his lover, who had intercourse with him between his thighs . . . ${ }^{140}$

Other anthropologists have reported finding similar institutions in other African societies. ${ }^{141}$

Quite underemphasized have been analogous institutions among woinen. Especially interesting along these lines is Judith Gay's study of "mummy-baby" games among Basotho girls in Lesotho. ${ }^{142}$ In contrast to woinen in many other African societies, those in Lesotho are particularly vulnerable, both economically and socially, because they are dependent upon males who tend to be einployed as migrant workers. For these women, relationships outside of marriage serve as important support networks, and young girls are mitiated into such relationships beginning with "1nummy-baby" games played in their grade school years. In a mummy-baby relationship, an older girl, acting as "mummy," develops an intimate, maternal association with a younger one, the baby. Typically, the munmy presents gifts to the baby, who reciprocates by obeying and respecting the mummy. The two share emotional and informational exchanges, and are physically intimate, relations wlich soinetimes include sexual intimacy. Rather than displacing inarriage, these relationships help to prepare younger girls for inarriage, including its rockier inoments. Though Gay's exploration is the most thorough, other scholars have documented similar female-feinale friendships in other African societies. ${ }^{143}$

140 Id. at $1429-30$.

141 See Walter Cline, Notes of the People of Siwah and el Garah in the Libyan Desert (Leslie Spier ed., 1936); Edmund Leach, Marriage, Legitimacy, Alliance, in Social Anthropology 176, 210 (1982) (discussing boy marriage in the Siwah Oasis in Western Egypt).

142 See Judith Gay, "Mummies and Babies" and Friends and Lovers in Lesotho, in The Many Faces of Homosexuality, supra note 122, at 97.

143 See, e.g., John Blacking, Fictitious Kinship Amongst Girls of the Venda of the Northern Transvaal, 59 Man 155 (1959). 


\section{b. Transgenderal Relationships}

Transgenderal unions have also been documented for some African societies. For example, "[t]he mugawe, a powerful rehgious leader of the Kenyan Meru, is considered a complement to the male political leaders and consequently must exemplify feminine qualities: he wears women's clothing and adopts women's hairstyles; he is often homosexual, and sometimes marries a man."144 Anthropological studies suggest similar berdache traditions among the Kwayama and Ovimbundu in Angola, the South African Zulu, the Ba-kongo im Zaire, the Nandi of Kenya, the Dinka and Nuer of Sudan, the Konso and Amhara of Ethiopia, the Ottoro of Nubia, the Fanti of Ghana, the Thonga of Zimbabwe, the Tanala and Bara of Madagascar, the Wolof of Senegal, and various tribes in Uganda. ${ }^{145}$

\section{c. Woman Marriage and Female Husbands}

A form of same-sex union that may be unique to African cultures is the institution of "feniale husbands" or "woman marriage." Noted as a mere curiosity by earlier researchers, the mstitution was not given much serious attention until it was publicized within the anthropological community in the 1930s by Eileen Jensen Krige and Melville Herskovits. ${ }^{146}$ Evans-Pritchard provided an early description of woman marriage:

What seems to us, but not at all to Nuer, a somewhat strange union is that $\mathrm{m}$ which a woman marries another woman and counts as the pater [father] of the children born of the wife. Such marriages are by no means uncommon in Nuerland, and they must be regarded as a form of simple legal marriage, for the woman-husband marries her wife in exactly the same way as a man marries a woman. ... We may perhaps refer to this kind of union as woman-marriage.

A woman who marries in this way is generally barren, and for this reason counts in some respects as a man. ... [I]f she is rich she may marry several wives. She is their legal husband and can demand damages if they have relations with inen without her consent. She is the pater [father] of their children, and on the marriages of their daugh-

144 Greenberg, supra note 47, at 60.

145 See id. at $60-61$.

146 See Melville J. Herskovits, A Note on "Woman Marriage" in Dahomey, 10 Africa 335 (1937); Eileen J. Krige, Note on the Phalaborwa and Their Morula Complex, 11 Bantu Stud. 357 (1937). 
ters she receives "the cattle of the father," and her brothers and sisters receive the other cattle which go to the father's side in the distribution of bridewealth. Her children are called after her, as though she were a inan, and I was told that they address her as "father." 147

Krige describes woman marriage as "the imstitution by which it is possible for a woman to give bridewealth for, and marry, a woman, over whom and whose offspring she has full control, delegating to a male genitor the duties of procreation." 148 Krige suggests that wonian marriage is "closely bound up with rights and duties arisnig from the social structure" of the culture, a "flexible nistitution that can be utilized in a number of different ways to ineet a number of different situations." 149 For example, in African cultures where women occupy a high position and can acquire property or other forms of wealth, woman marriage is one way that a woman may strengthen her economic position and establish her "household." Ifeymwa Olinke, whose tale was recounted in the imtroduction, was a powerful and prosperous woman who advanced her position by taking many wives.

Woman marriages were not uncommon im Africa. "The term female husband ... refers to a woman who takes on the legal and social roles of husband and father by marrying another woman according to the approved rules and ceremonies of her society. She may belong to any one of over 30 African populations," writes Denise O'Brien. ${ }^{150}$ She reports that the institution is most popular im three parts of Africa: (1) West Africa, especially Nigeria and Dahomey, ${ }^{151}$ (2) South Africa, including the Southern Bantu upon whom O'Brien

147 E.E. Evans-Pritchard, Kinship and Marriage Among the Nuer 108-09 (1951).

148 Eileen J. Krige, Woman-Marriage, with Special Reference to the Lovedu-Its Significance for the Definition of Marriage, 44 Afr. 11, 11 (1974).

149 Id. at 29.

150 Denise O'Brien, Female Husbands in Southern Bantu Societies, in Sexual Stratification: A Cross-Cultural View 109 (Alice Schlegel ed., 1977).

151 See id. at 110; Amadiume, supra note 2; Laura Bohannan, Dahomean Marriage: A Revaluation, in Marriage, Family, and Residence 85 (Paul Bohannan \& John Middleton eds., 1968), reprinted from 19 Africa 273 (1949); Herskovits, supra note 146. 
reports, ${ }^{152}$ and (3) East Africa ${ }^{153}$ and the Sudan. ${ }^{154}$ In contrast to Krige's view that woman marriage empowers women, O'Brien believes that the institution helps keep women in their subordinate place. Woman marriage, she argues, is usually a social adaptation by which a male-dominated society allows powerful wealthy women to take a leadership role, but only if they assume the social role of a man, acting as husband and father. ${ }^{155}$

\section{Asian Cultures}

Institutionalized same-sex unions historically existed throughout Asian cultures in one or more of the forms already described: the berdache tradition of transgenderal same-sex marriage (similar to that existing in Native American culture), companionate same-sex marriage (like that conteinplated in Plato's Symposium), and the transgenerational tradition of boy wives (also found in Plato and widely practiced in ancient Greece). In soine cultures, including Chinese society, all three of these types of same-sex relationships have flourished..$^{156}$

\section{a. Transgenderal Unions (Indian Hijras)}

In inany Asian cultures, the berdache tradition was quite strong, its adherents often forming transgenderal same-sex unions:

Among the Paleo-Siberians (Chukchee, Koryak, Kamchadal, Asiatic Eskimo), male shamans were ordered by a female spirit to dress as women. As the spirit often became a supernatural spouse who was jealous of earthly women, many of the shamans acquired male sexual partners who had intercourse with them anally, and most of them married other men. ${ }^{157}$

152 See O'Brien, supra note 150, at 110; Krige, supra note 148.

153 See O'Brien, supra note 150, at 110; H. Huber, "Woman Marriage" in Some East African Societies, 63/64 Anthropos 745-52 (1969); Regina S. Oboler, Is the Female Husband a Man? Woman/Woman Marriage Among the Nandi of Kenya, 19 Ethnology 69 (1980).

154 See O'Brien, supra note 150, at 110; Evans-Pritchard, supra note 147.

155 See O'Brien, supra note 150 , at 122 (conceding that Krige's description may hold for West African female husbands, for it seems that women in this society could attain great wealth without sacrificing their role as women).

156 See Bret Hinsch, Passions of the Cut Sleeve: The Male Homosexual Tradition in China 11-13 (1990). See generally Stephen O. Murray, Oceanic Homosexualities 151-256 (1992) (describing "gender-defined homosexuality in Asian oceanic cultures").

157 Greenberg, supra note 47, at 58. 
For example, the courtship and marriage of Chuckchee "soft men" has been described as follows:

The marriage [between a soft man and his husband] is performed with the usual rites, and I must say that it forms a quite solid union, which often lasts till the death of one of the parties. The couple live much in the same way as do other people. The man tends his herd and goes hunting and fishing, while the "wife" takes care of the house, performing all domestic pursuits and work. They cohabit im a perverse way, modo Socratis, in which the transformed wife always plays the passive role. ${ }^{158}$

In Vietnam, India, Burma, Korea, Nepal, the Austral Islands, New Zealand, and the Cook Islands, a similarly strong berdache tradition endured, with Chinese society countenancing a weaker convention practiced by eunuchs (castrated males charged with managing imperial harems). The mahus of eighteenth-century Tahiti were described in terms likewise recalling the berdache rite. The mahus were men who not only dressed in female garb, but also engaged in work traditionally performed by women, such as caring for babies, keeping house, and braiding palm leaves. Tahitian culture did not merely accept the mahus, but revered them, each district claiming one designated mahu and the principal chiefs taking them as wives. ${ }^{159}$

Probably the best documented example of transgenderal marriage in Asia takes place among the hijras of India, ${ }^{160}$ impotent or emasculated men who take on female garb and demeanor. The hijras earn their hiving by collecting alms and performing for currency at weddings, births, and festivals. Interviews by Serena Nanda confirm inany (but not all) earhier studies indicating that the hijra culture is one of institutionalized homosexuality, with marriage's cultural and hinguistic trappings adopted by most of its participants. Quoting from the hijras, Nanda describes their sexual relationships:

1587 Waldemar Bogoras, The Jesup North Pacific Expedition: The Chukchee 451 (reprint 1975) (Franz Boas ed., 1904-09); see also Williams, supra note 129, at 252-54 (describing Bogoras' work and providing accounts of "soft men" in other eastern Siberian cultures).

159 Greenberg, supra note 47, at 58-59. The best source for the mahu tradition is Robert I. Levy, The Community Function of Tahitian Male Transvestitism, 44 Anthropological Q. 12 (1971).

160 See Serena Nanda, The Hijras of India: Cultural and Individual Dimensions of an Institutionalized Third Gender Role, $11 \mathrm{~J}$. Homosexuality 35 (1985). The article has been expanded into book form. See Serena Nanda, Neither Man Nor Woman: The Hijras of India (1989) [heremafter The Hijras of India]. 
There are two modes of sexual relations among hijras. One is casual prostitution, the exchange of sexual favors with different men for a fixed sum of inoney, and the other is "having a husband." . .

Shakuntala clearly expressed a feminine gender identity and was, in fact, the person who came closest to what would be called in the west a transsexual that is, experiencing himself as a "fernale trapped in a male body." . . . She is currently involved in a long-term, monogamous relationship with a young man who hives im her neighborhood and whom she hopes will "marry" her. ...

Having a husband is the preferred alternative for those hijras who engage in sexual relations. Many of iny informants have, or recently had, a relatively permanent attachment to one inan whoin they referred to as their husband. They maintain warm and affectionate, as well as sexually satisfying and economically reciprocal, relationships with these inen, with whoin they hive, soinetimes alone, or soinetiines with several other hijras. ${ }^{161}$

\section{b. Companionate Unions (China)}

Conipanionate sanie-sex marriages, like transgenderal unions, were also common in Asia, their occurrence best documented in Chmese society. Literary sources fron1 the Zhou Dynasty (1122-256 B.C.) contain exainples of open affection between men; hike the Mesopotamian myth of Gilgamesh, some of the accounts describe the love shared between sanie-sex couples in terms akin to those used to recount the love exchanged between husband and wife. ${ }^{162}$ According to the official histories, ten of China's Han Eniperors (206 B.C. to 220 A.D.) enjoyed male lovers, pursuing open saine-sex liaisons similar to those enjoyed by their conteinporary Roman counterparts. ${ }^{163}$ Generally, these haisons should not be considered saine-sex marriages. Rather, the Han Eniperor would marry a woman to bear him heirs and take on one or more nuale favorites as lovers. But the leading scholar of Chinese sexuality, Bret Hinsch, beheves that Han society's tolerance of homosexual relations, the custom of male pair bonding

161 Nanda, The Hijras of India, supra note 161, at 44-45.

162 See Hinsch, supra note 156, at 15-33 (describing the homosexual traditions of the Zhou Dynasty generally); id. at 24-25 (providing the best example of a story relating a companionate relationship, i.e., the love of Wang Zhongxian for Pan Zhang).

163 See id. at 34-50 (listing the emperors and their male favorites and recounting some of their stories). 
and its celebration in poetry and other literature, and inen's incorporation of their male concubines into their liousehold are "clues to the origins of practices tliat later developed into same-sex marriages."164

Evidence of institutionalized same-sex inarriages in China is clearer during the Yuan and Ming Dynasties (1264-1644), the best evidence coming from the widely read seventeentli-century stories of $\mathrm{Li} \mathrm{Yu}$. Many of his stories speak openly of sexual relations and coinpanionate love affairs between 1 nen, ${ }^{165}$ a practice particularly associated with Fujian and other provinces in Southern China. In at least one story, Li Yu describes the tragic roinance of two men, Jifang and Ruiji, who become "liusband and wife." In describing the couple's wedding, $\mathrm{Li} \mathrm{Yu}$ goes out of his way to emphasize that the couple adhered to the forinal requisites of inarriage, sucl as bride-price and the various wedding rituals, giving some indication that similar samesex marriages were cominon in Soutliern China and perliaps elsewhere in the region. ${ }^{166}$ Hinsch infers from $\mathrm{Li} \mathrm{Yu}$ 's tale and other evidence that "men apparently found it desirable to construct loinosexual relationships along tlie lines of heterosexual marriage," 167 especially in Fujian, but further notes that same-sex relationships elsewhere were celebrated as "brotherly" unions, sworn friendships, and even adoptions ${ }^{168}$ —close but platonic relationships reminiscent of

164 Id. at 50.

165 See e.g, Li Yu, A Tower for the Summer Heat (Patrick Hanan trans., 1992).

166 See Hinsch, supra note 156, at 127-29 (discussing the couple's story). See generally James McGough, Deviant Marriage Patterns in Chinese Society, in Normal and Abnormal Behavior in Chinese Culture 171 (Arthur Kleinman \& Tsung-Yi Lin eds., 1981) (tracing the types of marriages in Chinese culture).

167 Hinsch, supra note 156, at 129; see also id. at 132-33 (providing further evidence of formalized same-sex inarriage in Fujian). Professor McGough states that

What is of interest is the institutionalization and permanence of such relationships. There is some fragmentary information tending to support [the story's] claim that there were institutionalized, marriage-hike, male homosexual unions in China.

It seems fairly clear to me, then, that there were at least in late Ming and Ch'ing China institutionalized relationships between males in some areas, and that these relationships were often expressed in terms of marriage and carried out in some [sic] the social forms connected with "regular" marriage.

McGough, supra note 166, at 187-88; see also Jonathan D. Spence, The Memory Palace of Matteo Ricci 226-31 (1984) (reaching the same conclusion); Vivien W. Ng, Homosexuality and the State in Late Inperial China, in Hidden from History: Reclaiming the Gay and Lesbian Past 76 (Martin N. Duberman, Martha Vicinus \& George Chauncey, Jr. eds., 1989) (same).

168 See Hinsch, supra note 156, at 131-32 (describing brotherly relationships, adoptive relationships, and a "ceremony for swearing friendship"). 
the early Christian Church's enfraternization ceremonies. Although the Manchus of the Qing Dynasty sought to discourage same-sex relationships, outlawing homosexual behavior in 1740, these alliances continued for centuries after peaking in the seventeenth century. ${ }^{169}$

Less is known of female same-sex unions in China. Although Hinsch credits accounts of woman-wornan unions (which he considers to have been marriages) formed during the Qing Dynasty, ${ }^{170}$ the first well-documented unions were those associated with the "marriage resistance movement" $171 \mathrm{~m}$ nineteenth- and early twentieth-century Southern China. The developinent of China's imternational silk industry during this period helped many women to attain economic independence. After acquiring this newly-found freedom, thousands of women renounced marriage and became sou hei. ${ }^{172}$ Upon deciding to becoine sou hei, a woinan took a fornial ceremomal vow to remain unwed at least for a time, inoved out of her parents' house, and built "spinster houses" with other sou hei. These women formed "sisterhoods" in which sinall groups of wornen (typically five to seven) would bond together for mutual support and affection. Andrea Sankar reports that physical as well as emotional bonds often developed between two or three of the sisters. ${ }^{173}$

Hinsch is prepared to go further than Sankar, claiming that sisterhood relationships shared many attributes of marriage.

Within the group, a lesbian couple could choose to undergo a marriage ceremony in which one partner was designated as "husband" and the other "wife." After an exchange of ritual gifts, the foundation of the Chinese marriage ceremony, a feast attended by female companions served to witness the marriage. These married lesbian couples could even adopt female children, who in turn could inherit family property from the couple's parents. ${ }^{174}$

169 See $\mathrm{Ng}$, supra note 167 , at $87-89$.

170 See Hinsch, supra note 156, at 177.

171 See Marjorie Topley, Marriage Resistancc in Rural Kwangtung, in Women in Chinese Society 67 (Margery Wolf \& Roxane Witke eds., 1975).

172 The term literally means " 'self-combers,' referring to the fact that they combed their own hair in the fashion of married women rather than allowing it to be done for them in a marriage ceremony." Andrea Sankar, Sisters and Brothers, Lovers and Enemies: Marriage Resistance in Southern Kwangtung, in The Many Faces of Homosexuality, supra note 122, at $69,69$.

173 See id. at 78-80.

174 Hinsch, supra note 156 , at 177-78; see also McGough, supra note 166 , at $185-86$ (providing another account of same-sex unions for women in China). 


\section{c. Transgenerational Unions (Japan and Melanesia)}

Transgenerational same-sex unions traditionally existed in a number of Asian societies, as well as in Melanesia and Australia. Feudal Japan institutionalized transgenerational hoinosexuality, especially in its samurai class of warriors. ${ }^{175}$ During the Tokugawa period, and especially during the seventeenth century, these transgenerational relationships were recorded in literary and other docuinents. What the Japanese called "boy love" is described in particularly great detail in Ihara Saikaku's The Great Mirror of Male Love, which has been translated and presented to an Enghish-speaking audience by Paul Gordon Schalow. In his introduction, Schalow says:

Since male love was a normal component of male sexuality, it was governed by ethical constraints very much like those governing sexual relations between men and women, particularly im the samurai class. ... [T] [he beginning of a relationship between a wakashu [boy] and an adult samurai was normally accomparied by a formal exchange of written and spoken vows, giving the relationship a marriage-like status. The verbal exchange of vows was formulaic and involved a promise to love in this life and the next (one step beyond our "till death do us part"). The wakashu Sannojo's vow with Kan'emon recorded in [story] 2:3, "His Head Shaved on the Path of Dreams," is fairly typical:

"Promise me your love will never change," Sannojo said.

"It will never change."

"Promise never to forget me."

"I will never forget you."

As in marriage, sex was only one element of the man-boy relationship. The adult male lover (called a nenja) was supposed to provide

175 Professor Greenberg elaborates:

A samurai warrior went to battle accompanied by a favorite youth, who also served as a sexual partner; for many he may have been the primary, though not necessarily exclusive, sexual outlet. Literary sources depict the relationships as highly romantic, sustained by undying loyalty. Sometimes samurais fought duels on behalf of their lovers. The relationships were not only accepted, but considered extremely desirable, especially in those regions of Japan where physical strength and military prowess were highly prized.

Greenberg, supra note 47 , at 260 ; see also Murray, supra note 158 , at 111,130 (describing "boy wives" of samurai in pre-mineteenth-century Japan). 
social backing, emotional support, and a model of manliness for the boy. In exchange, the boy was expected to be worthy of his lover by being a good student of samurai manhood. ${ }^{176}$

What is striking about Japanese transgenerational same-sex unions is not so nuuch their rhetorical links to niarriage as their importance as initiation rites. In this regard, these unions are similar not only to the boy love of the Greeks and the boy wives among the Azande warriors, but also to the niummy-baby games among Basotho girls.

The best docuniented example of brief same-sex relationships as rites of initiation has been the "ritualized homosexuahity" developed by aboriginal populations of Australia and the islands of Melanesia. ${ }^{177}$ Rituahzed honiosexuality is the term anthropologist Gilbert Herdt uses to describe the events whereby a boy entering manhood engages in a short-term sexual relationship with an older nian. By implanting his semen within the boy, the older man is thought to empower his younger partner, helping hin1 to coinplete the journey to viritity and manhood. According to Herdt, about fifty Melanesian societies practice sonie form of ritualized homosexuality.

In sonie conınunities, the rituahized nuan-boy relationship serves as a prelude to a traditional different-sex n1arriage. Shirley Lindenbaun1 has found that "[a] most striking aspect of social orgamization ni societies with rituahized niale homosexuality concerns the overlap between marriage and homosexual relationships."178 That is, by inseminating a boy the older male not only facilitates the boy's passage nito inanhood, but also prepares him for his marriage to a woman. Many of the Melanesian societies institutionalizing this ritual treat nuarriage not as an exchange relationship involving the paynient of bride-price, but as a conıplex niethod of bonding two families. In keeping with this notion, sonie of these cultures require a boy seeking to enter into nuarriage with a wonian to submit sexually to the wonian's brother. "Thus, hife force (as semen) flows between sanie-

176 Paul G. Schalow, Introduction to Ihara Saikaku, The Great Mirror of Male Love 1, 27 (Paul G. Schalow trans., 1990).

177 See generally Gilbert H. Herdt, Ritualized Homosexual Behavior in the Male Cults of Melanesia, 1862-1983, in Ritualized Homosexuality in Melanesia 1 (Gilbert H. Herdt ed., 1984) (discussing anthropological evidence of ritualistic same-sex practices in Melanesia); Gilbert H. Herdt, Guardians of the Flutes: Idioms of Masculinity (1981) (documenting such practices in Sambia).

178 Shirley Lindenbaum, Variations on a Sociosexual Theme in Melanesia, in Ritualized Homosexuality, supra note 177 , at 337,343 . 
sex and different-sex partners, linking individuals and groups in coinplex chains of mutual dependency and obligation."179

\section{Same-Sex Unions in the Modern West}

The inodern West-the culture of which we are the best informed -is historically peculiar, expressing hysteria about same-sex intimacy and seeking to suppress same-sex unions with a fervor not frequently observed in other cultures. Paralleling the story of that suppression is the West's construction of inversion, sodomy, and hoinosexuality over time. Because its construction of hoinosexuality coincided with Western Europe's domination of the world, the West's peculiarities have had a disproportionate influence on human history, with great social consequences for non-Western societies such as those surveyed in the previous Section.

\section{The West's Suppression of Same-Sex Unions}

The turning point in the West's attitudes toward same-sex unions or inarriages can be located in the thirteenth century. ${ }^{180}$ It was then that many secular governments enacted their first laws prohibiting sodomy and that the existing laws came to be inore stringently enforced. In an analogous fashion, the Church began to take a stronger stand against same-sex intimacy, and leading scholastic thinkers such as Albertus Magnus and Thomas Aquinas systematized theological argnments against such behavior. In contrast to the relatively open and tolerant attitudes expressed during the eleventh and twelfth centuries, Europe after 1200 acted in an increasingly persecutorial manner toward any kind of behavior that transgressed established gender lines, including not just same-sex intimacy but also aggressive, independent behavior such as cross dressing by woinen. ${ }^{181}$

179 Id. at 345.

180 See Boswell, supra note 46, at 269-332; Greenberg, supra note 47, at 268-92 (concerning the late Middle Ages), 301-46 (concerning the early modern period); Judith C. Brown, Lesbian Sexuality in Medieval and Early Modern Europe, in Hidden from History, supra note 167, at $67,72$.

181 For a documentation of medieval attitudes toward cross dressing, see Vern L. Bullough \& Bonnie Bullough, Cross Dressing, Sex, and Gender 45-73 (1993) (noting that male cross dressing was viewed as very problematic through most of medieval period and that female cross dressing was of less concern generally, but was feared when used to assert female power, as was the case with Joan of Arc in the fifteenth century). For a discussion of the European witch-craze, which provided society with a means by which to scrutinize independent, 
Huon of Bordeaux, an early thirteenth-century version of the French romance, illustrates this poimt. ${ }^{182}$ Ide, the work's female protagomist, dressed im man's garb and surreptitiously employed her skill as a warrior with such proficiency so as to earn her not only a knighthood, but also the hand of the emperor's daughter im marriage. Ide went through with the marriage ceremony but later revealed the truth to her bride, who tattled to her father. Condemning the possibility of "boggery" between the two women, the emperor decreed that Ide must be burned to death. Though Ide was saved at the last minute by metamorphosizing into a man, the drastic pumshment imposed for her predicament was consistent with the harshened thirteenth-century attitudes towards same-sex intimacy and cross dressing.

Why this shift in attitudes occurred is not clear, but it can be said that it comcided with the quickeming of a culture in the West that was urban, bourgeois, and statist. This contemporary urban culture created more occasions for people to find, pursue, and enjoy same-sex partners, and the increasmg economic opportumities available to the bourgeoisie gave substantial numbers of men more freedom to choose and diversify the nature of their sexual liaisons, to mclude same-sex as well as different-sex experiences. Although urbamzation allowed many men to enter imto and enjoy same-sex relationships, it also rendered such activity more prominent and potentially destabihzing. ${ }^{183}$ Same-sex relationships formerly practiced primarily in the discreet closets of nunneries, monasteries, and royal courts were less likely to remaim unobserved in this bustling urban environment, becoming more open or apparent, and thereby more troubling.

At the same time that urbanization forced society to face this and other aberrations, such as spinsters, religious nonconforımists, and the like, powerful nation- and city-states were emerging in the West. The

threatening women and spinsters, see H. R. Trevor-Roper, The European Witch-Craze of the Sixteenth and Seventeenth Centuries, in The European Witch-Craze of the Sixteenth and Seventeenth Centuries and Other Essays 90 (1969) (noting that the intellectual origins of the early modern witch-craze were laid in the period 1200-1500, marking a dramatic shift from earlier attitudes that refused to believe in witches).

182 See Huon of Bordeaux (Sir John Bourchier \& Lord Berners trans., 1895).

183 See Lawrence Stone, The Family, Sex and Marriage in England 1500-1800, at 215-18 (1977) (arguing that the sovereignty of the state was linked in popular iniagination to the sovereignty of the father heading a family of obedient wife and children and that, hence, any attack on the nuclear family during this period was viewed as a politically and socially destabilizing event). 
political powers taking this new form flexed their muscles against aberrant groups, and state aggression directed against Jews, heretics, and witches becaine prominent after 1200.184 Guido Ruggiero's history of sex crimes in Venice cliaracterizes the persecution of saine-sex behavior as, hiterally, a "witch hunt," reflecting both the contemporary anxieties and the awesome power of the new Leviatlian. ${ }^{185}$

Jews, heretics, witches, and inverts encountered similar historical patterns of identification, segregation, and harassment. Though medieval society disapproved of certain forms of conduct, including expression of heretical behefs, devilish behavior, and sodomy, before 1200 no systenuatic theory explained why certain acts were proscribed, and such conduct was penalized mildly and episodically. After 1200 , lowever, medieval thinkers developed theories that rendered nonconforming behaviors alarming threats, and societies accordingly began to penalize nonconforming conduct more systematically and harshly. Real historical parallels to the story of Ide abound. Joan of Arc, for example, was burned at the stake for engaging in a laundry list of interrelated nonconformities-heresy (she bypassed the Church and claimed to speak directly with the spiritual

184 Boswell suggests that the state's act of repressing same-sex relationships was probably closely related to the general increase in intolerance of minority groups apparent in ecclesiastical and secular institutions throughout the thirteenth and fourteenth centuries. Crusades against non-Christians and heretics, the expulsion of Jews froin inany areas of Europe, the rise of the Inquisition, efforts to stamp out sorcery and witchcraft, all testify to increasing intolerance of deviation from the standards of the inajority, enforceable for the first time in the newly emerging corporate states of the High Middle Ages.

Boswell, supra note 46, at 334; see also Grecnberg, supra note 47, at 279 (discussing the intolerance of homosexuality einerging in the thirteenth century); Vern L. Bullough, Postscript: Heresy, Witchcraft, and Sexuality, in Sexual Practices \& the Medieval Church 206 (Vern L. Bullough \& James Brnndage eds., 1982) (discussing the association of forbidden sexuality with heresy and witchcraft in the twelfth and thirteenth centuries); Trevor-Roper, supra note 181, at 110-15 (noting that for purposes of medieval scapegoating, witches and Jews were virtually interchangeable, both representing social nonconformity).

185 See Guido Ruggiero, The Boundaries of Eros: Sex Crime and Sexuality in Renaissance Venice 140 (1985) (footnotes omitted):

Outsiders sexually, from the perspective of the threatened doininant culture, both witches and hoinosexuals engendered a fear based, on the one hand, on man's powerlessness to stand up to their seeiningly growing powers and, on the other hand, on God's threatened wrath against societies that tolerated such ungodly ways. In both cases inan had the power to literally burn the danger out of society. . . . Both hoinosexuals and witches were, in a way, among the first victims of a more aggressively organized society flexing its new inuscles of discipline and control. 
world), witchcraft (the voices she heard and followed were called demonic), and imversion (her dressing as a man defied gender roles). ${ }^{186}$

During the early modern period (about 1400-1700), society's obsession with bad conduct gave way to an obsession with bad categories of people. Attention shifted from persecuting specific conduct evincing heretical behefs to identifying and excluding "heretics," from forbidding deinomic behavior to identifying and excluding "witches," and from penahizing inverted sexual behavior to identifying and excluding "inverts," or people who engaged in crimes against nature (bestiality, sodoiny, and so forth). Eventually, isolated prosecutions of individuals engaging in bad conduct gave way to hysterical persecutorial crazes that swept up throngs of people in popular, ecclesiastical, and official dragnets.

Thus, same-sex unions, which had been viewed as merely probleinatic during the Middle Ages, were beheved in the early modern period to constitute a severe threat to the social order and the now-powerful state. For example, even as Montaigne was reporting that same-sex marriages were perforined in Rome in the Church of St. John during the $1570 \mathrm{~s},{ }^{187}$ other observers reported that some of the male couples married in St. John's were later burned in the city square. ${ }^{188}$ Also set in motion in the West was a spiraling and somewhat paradoxical discourse detailing, highlighting, and condemning same-sex relations. Fascinated by the variety of sexual experiences, but at the same time repelled by a force that might destabilize marriage and reduce needed population, Western priests, bureaucrats, and morahists engaged in a chatty cainpaign to cleanse their communities that succeeded in forcing same-sex couples underground, while at the same time unintentionally feeding people's imterest in inverts. Historians have docuniented commurities (or ghettos) of male and female inverts in Europe's major urban centers during the early modern period. ${ }^{189}$

186 See Marina Warner, Joan of Arc (1981). I also consider George Bernard Shaw's screenplay strikingly insightful on this point. See George B. Shaw, Saint Joan: A Screenplay 101-02 (Bernard F. Dukore ed., 1968) .

187 See Michel de Montaigne, Journal de Voyage en Italie par la Suisse et l'Allemagne en 1580 et 1581, at $231 \& 481$ n.515 (Charles Dedeyan ed., 1946).

188 See Spence, supra note 167, at 226.

189 See, e.g., Theo van der Meer, Tribades on Trial: Female Same-Sex Offenders in Late Eighteenth Century Ainsterdam, in Forbidden History: The State, Society, and the Regulation of Sexuality in Modern Europe 189 (John C. Fout ed., 1992); Randolph Trumbach, Sex, 
During the nineteenth century, the West went one step further in its categorization gaine. The invert became the hoinosexual, ${ }^{190}$ as a new breed of doctor-"sexologists"-came to see sexual affinity not just as a way to categorize and stigmatize a person for his or her activities, but as a "sexual orientation," an essential part of one's personality and physical inake-up. And because a "normal" sexual orientation was heterosexual, being physically attracted to people of the saine sex became not only a homosexual orientation but also a sexual "deviance," a medical disease. Because physical or inental deviations might be treatable, the doctor replaced the bureaucrat (who had earhier displaced the inquisitor) as society's police officer. By deeming homosexuahty a disease, the medical profession contributed to a new wave of hysteria and persecution in the West during the middle part of the twentieth century, a reaction that was especially veheinent in the Uinited States.

Unlike cultures in the Americas, Asia, Africa, and Australia, the modern West has not been hospitable to same-sex unions. Yet the West's hostile reaction to same-sex unions and its state-sanctioned suppression of thein affected other cnltures' attitudes toward such unions. Just as Western-nation-states in the early inodern period conquered the New World and killed most of its people, colonized and enslaved Africa, and cartelized and evangelized Asian cultures, so they exported their anti-hoinosexual attitudes and aggressively suppressed these cultures' indigenous attitudes and institutions.

Thus, the Spanish persecuted the berdache tradition in what is now Latin America, ${ }^{191}$ with the United States supporting a less concerted campaign against such relationships as it stripped Native Americans of their land and culture. ${ }^{192}$ Slave traders and colonial administrators

Gender, and Sexual Identity in Modern Culture: Male Sodomy and Female Prostitution in Enlightenment London, in Forbidden History, supra, at 89.

190 See Jeffrey Weeks, Sex, Politics, and Society: The Regulation of Sexuality Since 1800, at 102-03 (1981); George Chauncey, Jr., From Sexual Inversion to Homosexuality: Medicine and the Changing Conception of Female Deviance, in Homosexuality: Sacrilege, Vision, Politics 114 (Robert Boyers \& George Steiner eds., 1982-83).

191 See Guerra, supra note 116, at 221-25.

192 See Williams, supra note 129 , at 175 :

Male marriages, and berdaches themselves, could not survive undisturbed when representatives of the established social order arrived. Their history after the frontier era is part of the wider story of the effect of Anglo-American dominance on American Indian cultures generally. It is a story of cultural repression by the church and the state, leading to the decline of the old ways, and an acculturation to the new alien 
broke up family institutions (including same-sex family institutions) in Africa and soinetimes disrnpted economic patterns that gave woinen standing and authority to command feinale inarriages. Missionaries in Africa, China, Japan, Melanesia, and other cultures miposed an increasingly rigid, official Christian view of sexuality and inarriage upon "converted" peoples, discouraging and soinetimes persecuting traditional practices, including same-sex unions. ${ }^{193}$

\section{The Survival of Same-Sex Unions in the West}

Although the inodern turn in Western attitudes and their ascendancy in the world surely threatened same-sex relationships and inarriages, Western condemnation did not end thein, either in Europe or the rest of the world. ${ }^{194}$ Same-sex unions not ouly survived during this period of repression, but flourished even in the West, albeit in different ways at different times. Throughout the inodern period, same-sex unions have flourished at the fringes of society. The inost interesting ways in which same-sex unions have persisted have been those institutions that have undermined lines of gender identification in the inodern era.

\section{a. Same-Sex Relationships and Boston Marriages}

Wonien's sanie-sex unions in the modern period have been differently situated fronı nien's until this century. In the sixteenth century, the Seigneur de Brantôme wrote of sex between woinen with a tolerance he would not have shown for inale sodoniy. ${ }^{195}$ The apparent reason for this anoinaly is that he, like others, viewed only intercourse as sex, finding same-sex relations potentially threatening only when a penis was involved. Thus adultery was wrong, and niale sodoiny virtually unspeakable. But under the views prevaihing in the sixteenth century, nothing was at stake when a wonian cavorted with another woinan because intercourse, per se, could not take place. Indeed,

values. But it is also a story that is narked by a surprising continued persistence of Native American traditions, even into the contemporary era.

193 See, e.g., Spence, supra note 167, at 227-32 (noting that the Jesuits' persecution of Chinese and Phillipino citizens for having homosexual relations was acceptable in Asia).

194 According to Boswell, for example, Roman Catholic and Greek Orthodox priests continued to perform same-sex marriage ceremonies into the nineteenth century. See Boswell, 1500 Years of Blessing, supra note 114.

195 See Seigneur de Brantôme, Lives of Fair \& Gallant Ladies 131-34 (A.R. Allinson trans., 1933). 
Brantôme effervesced that many husbands "were right glad their wives did follow after this sort of affection rather than that of men, deeming them to be thus less wild."196

Thus, female-female intimate relationships could be conducted opeuly, because women were themselves considered sexually marginal. Historian Lillian Faderman has documented dozens of examples of intense, marriage-like friendships between pairs of women; these same-sex relationships flourished from the Renaissance to the twentieth century. ${ }^{197}$ Passionate female-female friendships genumely took off as a social phenomenon in the eighteenth century, when women's needs for intellectual and emotional respect far outstripped the ability of socialized males to meet those needs and when many women had the economic means to be independent of men. For many women, these female friendships generated a great deal more emotional intensity than they could find in marriages. ${ }^{198}$ For example, the celebrated "Ladies of Llangollen," Sarah Pononsby and Eleanor Butler, disguised themselves as men and eloped together in 1778. They settled down im Llangollen Vale im 1780 and shared every moment together for the next fifty-three years. ${ }^{199}$ Their "Davidean friendship" (as poet Anna Steward termed $i^{200}$ ) became a celebrated romantic ideal, and the ladies' friend William Wordsworth described them as follows:

"Sisters in love, a love allowed to climb

Ev'n on this earth, above the reach of time."201

The ladies' union is the best documented of this period, but Faderman has found evidence of many other romantic female relationships occurring throughout the late eighteenth century. ${ }^{202}$

These relationships proliferated in the nineteenth century, as women's expanded economic opportunities gave them greater freedom to marry or not and to fashion their own personal relation-

196 Id. at 131.

197 See Lillian Faderman, Surpassing the Love of Men: Romantic Friendship and Love Between Women from the Renaissance to the Present (1981).

198 Id. 74-84.

199 See Elizabeth Mavor, The Ladies of Llangollen: A Study in Romantic Friendship (1971).

200 See Faderman, supra note 197, at 121.

201 Id. (quoting Wordsworth).

202 Id. at 125-43. "What romantic friends wanted was to share their lives, to confide in and trust and depend upon each other, to be there always for each other." Id. at 142. 
ships. ${ }^{203}$ The inhabitants of this era even came up with a name for a "long-term monogamous relationship between two otherwise unmarried women"- $a$ "Boston marriage," so-called because these relationships were so similar to the hives of a female couple in Henry James' 1885 novel, The Bostonians. ${ }^{204}$ Boston marriages were very popular among well-educated, professional women in particular.

The emotional, and perhaps sexual, needs that Boston marriages filled for women found parallels in inale compamonate relationships during the nineteenth century. Males finding themselves in frontier communities without women formed personal, and often sexual, partnerships with other men-includimg communities of pirates, ${ }^{205}$ hoboes, ${ }^{206}$ cowboys, ${ }^{207}$ and mimers. ${ }^{208}$ In the nineteenth century, male romantic relationships-like Boston marriages-were not uncommon. For example, Thomas Wentworth Higginson wrote of his Harvard classmate, William Henry Hurlbut, "I never loved but one male friend with passion-and for him my love had no bounds-all that my natural fastidiousness and cautious reserve kept from others I poured on him; to say that I would have died for him was nothing. I hived for him ...."209 Notwithstanding this passionate language, there is no evidence that Higginson and Hurlbut engaged in sexual

203 Id. at $178-89$.

204 Id. at 190-230. For descriptions of similar relationships in the twentieth century, see Leila J. Rupp, "Imagine My Surprise": Women's Relationships in Mid-Twentieth Century America, in Hidden from History, supra note 167, at 395.

205 See B.R. Burg, Sodomy and the Perception of Evil: English Sea Rovers in the Seventeenth-Century Caribbean (1983); see also Williams, supra note 129, at 153-57 (describing pair-bonding among pirates as "de facto male marriages").

206 See Josiah Flynt, Homosexuality Among Tramps, in Studies in the Psycloology of Sex 359 (Havelock Ellis ed., 1942).

207 See Williams, supra note 129 , at 162 (reporting that cowboy partners formed stable "male marriages"); id. at 169-74 (explaining that cowboys would often settle down into "Indian-white male marriage" with berdaches).

208 See T. Dunbar Moodie, Migrancy and Male Sexuality on the South African Gold Mines, in Hidden from History, supra note 167, at 411 (describing "inine marriages" in which male "wives of the mine" would be sexually passive partners in lovemaking and would perform traditional wifely chores).

209 Robert K. Martin, Knights-Errant and Gothic Seducers: The Representation of Male Friendship in Mid-Nineteenth-Century America, in Hidden From History, supra note 167, at $169,179$. 
activities, though there is such evidence for other male-bonded friends of that era. ${ }^{210}$

The poet Walt Whitman sought to describe this "manly love," this "love of comrades" in the forty-five Calamus poems publislied in the 1860 edition of Leaves of Grass. ${ }^{211}$ Thougli modestly closeted by today's standards, Whitman's poeins were scandalous in their sexually liberatory message:

Clear to me now, standards not yet publislied-clear to me that my Soul,

That the Soul of the man I speak for, feeds, rejoices only in comrades;

Here, by myself, away from the clank of the world,

Tallying and talked to here by tongues aromatic,

No longer abashed-for in this secluded spot I can respond as I would not dare elsewliere,

Strong upon me the life that does not exhibit itself, yet contains all the rest,

Resolved to sing no songs to-day but those of manly attachment,

Projecting them along that substantial life,

Bequeathing, lience, types of athletic love,

Afternoon, this delicious Nintli Montl, in my forty-first year,

I proceed, for all who are, or liave been, young men,

To tell the secrets of my niglits and days,

To celebrate the needs of comrades. ${ }^{212}$

Whitman was tlie century's master of an ambivalent, barely concealed hoinoeroticism.

In 1869, German psychiatrist Carl von Westphal published a case study of a woman who cross dressed and was attracted sexually to other women. ${ }^{213}$ Althougli sucli preferences presented nothing new, Westphal's prognosis did: the woman, he concluded, was a "congenital invert" whose abnormality was not an adaptation to the boring lot women faced day in and day out, but was instead a result of plysical

210 E.g., Martin N. Duberman, Writhing Bedfellows in Antebellum South Carolina: Historical Interpretation and the Politics of Evidence, in Hidden From History, supra note 168 , at 153.

211 Justim Kaplan, Walt Whitman: A Life 233 (1980).

212 Id. at $44-45$ (quoting the first poem in Calamus).

213 See Faderman, supra note 197, at 239 (describing von Westphal's study and its reception). 
degeneration and mental neurosis. ${ }^{214}$ Westphal's study and subsequent ones conducted by Richard von Krafft-Ebeling and Havelock Ellis were a nineteenth-century sensation, hailed by people interested in and frightened by women's increasing hiberation from men. Once the category of the "true imvert" (later renamed the "homosexual") was created by these sexologists, same-sex friendships, heretofore quaimt (for women) or "manly" (for men), became sexualized. Boston marriages became objects of suspicion in Europe by 1900, and in the Urited States by $1920 .^{215}$ Whitman's poetry took on new meaning, as evidence that he was a "male imvert," a "woman's soul in [a] man's body."216

\section{b. Passing Women and Same-Sex Marriages}

Although romantic same-sex friendships were ouly a cultural imstitution, and Boston marriages not lawfully sanctioned, some fenale couples often legally married even in the modern era. This was often accomplished through the phenomenon of "passing," in which a woman would not only dress in men's clothing, but actually pass for a man in several aspects of life. Although hundreds of women are known to have passed during the early modern era when women's aspirations grew faster than the opportumities actually accorded by society, ${ }^{217}$ the story of Elena de Cespedes (1545-88) is particularly interestimg. ${ }^{218}$ Elena escaped from the traditional women's work of weaving by dressing and passing as a man, becommg a soldier, and then a tailor named Eleno. Eventually Eleno fell in love with a peasant woman and obtained a hicense to marry her after passing a physical inspection designed to establish "his" manhood. Unhappily, Eleno's former lover challenged the forthcoming marriage on grounds of fraud, asserting that the first inspection was simply inaccurate and that Eleno was really a woman. In response to this challenge, the Madrid authority ordered a more thorough inspection to be conducted by physicians and surgeons, who once again pronounced

\footnotetext{
214 Id.

215 See id. at 239-53, 297-313. After 1920, Freud's theory of homosexuality as a developmental snafu replaced the congenitalist theory of Krafft-Ebing. Id. at 314-17.

216 See Dr. W.C. Rivers, Walt Whitman's Anomaly (1913), excerpted in Martin Duberman, About Tine: Exploring the Gay Past 106, 108 (1991).

217 See Bullough \& Bullough, supra note 181, at 94-112.

218 See id. at 94-96.
} 
Eleno a man. Following the marriage, Eleno was inspected for yet a third time, and on this occasion the examiners determined that Eleno, the husband, was a woman. After the damning verdict was rendered, Elena was referred to the Inquisition, where she was convicted of devilry.

Elena's case was far from unusual in the early modern period. Records kept by the Dutch East India Company reveal hundreds of women who were caught passing as men so that they could travel to the Indies. Some of these passers married men, but others among them married other women. ${ }^{219}$ Although a considerable number of women who passed as men did so to attain a more exciting lifestyle, to fulfill personal ambitions, or for econoimic or intellectual reasons, it appears that many impersonated men at least im part im order to enjoy imtimate relationships with other women. Given these substantial and varied mcentives, it should not be surprising that the early modern period saw many woinen passing as men and a considerable number of inarriages between women. ${ }^{220}$ Moreover, a surprising number of passing women further crossed traditional gender lines by joining the armed forces, apparently escaping detection even in the close confines of military life. 221

Women passed as men just as easily in the Uinted States as they did in Europe for a similar mix of econoimc, social, and personal reasons. ${ }^{222}$ To illustrate, it is estimated that four hundred women passed as men in order to serve in the Umion Army during the Civil War. ${ }^{223}$ Of the women who passed as men, a substantial number sought female relationships, and hundreds of passing women legally married

219 Id. at 97-98. These were only the passing women who were found out, usually by accident. Surely there were many others who successfully passed and therefore never entered the records.

220 See id. at 100-03, 134-38, 164-68. For example, in the late eighteenth century it was reported that a passing woman married three different wives, each of whom thought she was a man. Id. at 134 .

22I Id. at 99-103, 157-64; see Juke Wheelwright, Amazons and Military Maids: Women Who Dressed as Men in the Pursuit of Life, Liberty and Happiness (1989).

222 See Katz, supra note 116, at 209-79 (devoting an entire section to "Passing Women: 1782-1920"); The San Francisco Lesbian and Gay Hist. Project, "She Even Chewed Tobacco": A Pictorial Narrative of Passing Women in America, in Hidden from History, supra note 167, at $183-94$.

223 Bullough \& Bullough, supra note 181, at 158. 
other women. ${ }^{24}$ Mary Anderson, for example, passed as Murray Hall in New York City for thirty years before her death in 1901. ${ }^{225}$ Hall made boatloads of money, was active in Tammany Hall politics, gamed a reputation as a "man" about town, and married twice, the first marriage ending in separation and the second cut short by her wife's death.

An interesting history is that of Nicholai de Raylan, who passed as a man named Nicholas de Raylan, a masquerade that proved a success apparently for most of her days. According to an account of her life authored by Dr. Havelock Ellis:

She was born in Russia and was in many respects very feminine, small and shight in build, but was regarded as a man, and even as very "Inanly," by both men and women who knew her intimately. She was always very neat in dress, fastidious in regard to shirts and ties, and wore a long-waisted coat to disguise the lines of her figure. She was married twice in America, being divorced by the first wife, after a union lastimg ten years, on the ground of cruelty and misconduct with chorus girls[!] The second wife, a chorus girl who had been previously inarried and had a child, was devoted to her "husband." Both wives were firmly convinced that their husband was a man and ridiculed the idea that "he" could be a woman. I am informed that De Raylan wore a very elaborately constructed artificial peris. In her will she made careful arrangeinents to prevent detection of sex after death, but these were frustrated, as she died in a hospital. ${ }^{226}$

According to another account of de Raylan's hife, the two wives were imcredulous that their husband had been a woman and expressed no regrets about their inarriages, which they considered quite satisfactory. ${ }^{227}$

\section{c. Lesbian and Gay Subcultures}

The strict rules regulatimg gender and marriage embedded within and enforced by Western culture, in the Umited States and elsewhere, mduced those who wanted to pursue same-sex relationships to find some means of escaping the predominant culture's strictures. A

224 For several documented examples, see Katz, supra note 116, at 225-26, 232-38, 240-42, 248-49, 250-51, 254-79.

225 Bullough \& Bullough, supra note 181, at 164.

$226 \mathrm{Katz}$, supra note 116, at 250 (quoting Dr. Ellis) (footnote omitted).

227 See id. at 251. 
number of those seeking sexual freedom migrated to the fringes of the frontier, some of who settled im mining communities. Others managed to pursue their desires by brandishing gender disguises (the passing women) or by prudently fashioning seemmgly platonic friendships. As modern Western culture became increasingly interested in sexuality and strengthened its accompanying concept of sexual "deviance," nuore and more people who were primarily attracted to individuals of the same sex gravitated to underground communities inhabited by like-feeling residents-i.e., to subcultures of sexual inverts, usually situated in urban areas. Such subcultures existed in London (the "nnolly houses"), Paris, inost nnajor Dutch cities, including Amsterdam, inost major Italian cities, including Venice, and elsewhere by the early eighteenth century. ${ }^{228}$ Although the state authorities persecuted those seeking refuge in these subcultures, sonietimes ruthlessly, people attracted to those of the same sex nonetheless flocked to them in search of sexual partners, with whom they often formed relationships. On occasion such couples were legally inarried. Dirk Jaap Noordain, for example, describes a female couple who managed to inarry in the Netherlands in the sixteenth century, as well as several female couples who tried to wed but were unsuccessful. ${ }^{229}$ Noordam also describes male couples who entered into permanent nuarriage-like relationships during that period, and notes finding at least one "niarriage contract" made by such a couple. ${ }^{230}$

As the West's conflicted interest in same-sex intimacy intensified, and especially after it was transformed in the late nineteenth century by the sexologists, inore and more people who desired same-sex relations turned to urban gay subcultures. For women, these communities appeared especially attractive. Though women could still attempt to pass as nien, the elaborate niasquerade became less necessary as

228 See generally The Pursuit of Sodomy: Male Homosexuality in Renaissance and Enlightenment Europe (Kent Gerard \& Gert Hekma eds., 1989) (describing the development and existence of such subcultures in fifteenth- to eighteenth-century Europe); 'Tis Nature's Fault: Unauthorized Sexuality During the Enlightenment (Robcrt P. MacCubbin ed., 1987) (describing same in the eighteenth century).

229 See Dirk J. Noordam, Sodomy in the Dutch Republic, 1600-1725, in The Pursuit of Sodomy, supra note 228 , at $207,212-13$.

230 See id. at 217. Sometimes, people in these subcultures would use terms like "marriage" and "wedding" in an ironic or sarcastic way. See, e.g., Alan Bray, Homosexuality in Renaissance England 86 ( 2 d ed. 1986). Bray reports that in a molly house, the "chapel" was where one had sex with one's "husband" on a "wedding might." Id. I am not including facetious or mocking references such as these in this history. 
women's economic opportunities increased. With Boston marriages despoiled by the sexologists, and passing more trouble than it was worth, women desiring same-sex intimacy turned to lesbian subcultures in the 1920s. The most vibrant subculture was that flourishing in Harlem:

While homosexual men were sometimes being run out of small white towns . . . in Harlem tolerance extended to such a degree that black lesbians in butch/femme couples married each other in large wedding ceremonies, replete with bridesmaids and attendants. Real marriage hicenses were obtained by masculinizing a first name or having a gay male surrogate apply for a license for the lesbian couple. Those licenses were actually placed on file in the New York City Marriage Bureau. The marriages were often common knowledge among Harlem lieterosexuals. ${ }^{231}$

While most upper class lesbians in the 1920s and 1930s dared only to continue the somewhat muted Boston marriage tradition, if they chose to pursue same-sex relationships at all, working class lesbians in the Umited States formed open "butch-femme" haisons that were often committed and lastimg. ${ }^{232}$

Male homosexual communities also boasted long-term same-sex relationships, which were recounted in an early essay by Donald Webster Cory and John LeRoy, who described "mock weddmg[s]" at which "all the formalities of an actually legally certified and religiously sanctioned ceremony are carefully copied."233 They contimued:

Cases liave been known of an all-male couple, one of whom will don an expensive bridal gown, or if they are both feinales, one of the women will wear a tuxedo. Engraved invitations are sent out, an elaborate cake is baked, and a banquet is prepared. If a "gay" (homosexual) religious official is known, his services niay be sought. . . .

231 Lillian Faderman, Odd Girls and Twilight Lovers: A History of Lesbian Life in Twentieth-Century America 73 (1991); see also Eric Garber, A Spectacle in Color: The Lesbian and Gay Subculture of Jazz Age Harlem, in Hidden from History, supra note 167, at 318 (describing the cultural contributions of the gay and lesbian community in Harlem).

232 For the best account of the development of the butch-feinine subculture, see Elizabeth $\mathrm{L}$. Kennedy \& Madelime Davis, "They Was No One to Mess with": The Construction of the Butch Role in the Lesbian Community of the 1940s and 1950s, in The Persistent Desire: A Femme-Butch Reader 62 (Joan Nestle ed., 1992).

233 Donald W. Cory \& John LeRoy, Homosexual Marriage, 29 Sexology 660 (1963). The name Cory is a pseudonym, and the name LeRoy is probably one too. 
With or without the aid of a religious official, however, some form of ceremony may take place in which the partners vow lifelong devotion to each other, and the wedding rings are put in place. The bridal march is played, while the guests follow the patterns of normal weddings. ${ }^{234}$

On the eve of Stonewall, the authors concluded with regret that social and other pressures usually combined to make these same-sex marriages short-lived. ${ }^{235}$

\section{Gay Rights and Same-Sex Marriage}

The June 1969 riots triggered by a police raid of the Stonewall Bar in Greenwich Village did for gay and lesbian liberation what the lunch counter sit-ins did for the African-American civil riglits moveinent: the riots provided martyrs, demonstrated open resistance to oppressive social practices, and created a focal point for future struggle. Altliougli the gay and lesbian rights movement in the United States started as early as the 1950 s, it made dramatic progress only after 1969.

As lesbians, gay inen, and bisexuals have becoine inore open about our sexuality, and as our own subculture has grown, tliere have been more long-term same-sex relationships than ever before in human history. Many same-sex couples consider themselves married for all intents and purposes, and rabbis, priests, and ministers have married literally thousands of these couples in religious services. ${ }^{236}$ Much of the early dialogue discussing marriage within the gay and lesbian community is captured in the Mendola Report, ${ }^{237}$ whicl is based upon Mary Mendola's survey of same-sex couples in the 1970s. Her respondents overwhelmingly considered theinselves "married." Mendola summarizes her findings as follows: $53 \%$ of the respondents believed marriage to constitute "a commitinent between two people"; $12 \%$ defined gay marriage as "an interpersonal relationship between two men or two women"; $19 \%$ viewed it as "companionship"; and

234 Id. at 660.

235 See id. at 661 .

236 See Suzanne Sherman, Introduction to Lesbian and Gay Marriage: Private Commitments, Public Ceremonies 1, $4-7$ (Suzanne Sherman ed., 1992) [hereinafter Lesbian and Gay Marriage].

237 Mary Mendola, The Mendola Report: A New Look at Gay Couples 48-53 (1980) (encompassing a section entitled "Gays Define Their Marriages/Relationships"). The material quoted from Mendola's interviewees is dominated by marriage metaphors. 
$12 \%$ focused on "the self-actualization of both people within the relationship."238

The Mendola Report's anecdotal conclusions are borne out by more rigorously conducted empirical surveys conceived during the 1970s. One important work studying gay and lesbian couples found that they developed a variety of relationships, with those attaining "close-coupled" (marriage-like) stability considered the happiest by the study's authors. ${ }^{239}$ Academic and empirical examinations of same-sex relationships conducted in the 1960 s and 1970 s found them functional im and of themselves but terminally shackled by social prejudice, legal disadvantages, and economic discrimination. ${ }^{240}$ One study summarized the evidence in this way:

The gay relationship does not receive the financial subsidies that the heterosexual marriage enjoys, in the forms of reduced taxes and discounts given to married couples by many private associations and businesses. . . . It would seein the lack of institutional and financial supports to gay marriages, intentionally withheld by the dominant heterosexual culture, is a potential contributor to the often-mentioned instability and ephemerality of gay relationships. Since it has been found in a variety of cultures that economic and institutional supports contribute to the stability and longevity of heterosexual haisons, it would seem somewhat arbitrary to argue that such supports have hittle relevance to the case of gay marriages. ${ }^{241}$

As gay and lesbian couples have come to form more lasting relationships, many of them viewing their unions as not materially different from heterosexual marriages, gaylaw has insisted that the state not only tolerate same-sex unions, but recognize them as marriages, or at least as something marriage-hike through domestic partnership laws. This brings our story back to its startimg point: the various arguments for and against recognizing same-sex marriage.

238 Id. at 53.

239 See Alan P. Bell \& Martin S. Weinberg, Homosexualities: A Study of Diversity Among Men and Women 199 (1978).

240 See Joseph Harry \& William B. DeVall, The Social Organization of Gay Males 80-100 (1978) (encompassing a section entitled “Marriages Between Gay Males”).

241 Id. at 80-81 (citations omitted). 


\section{Implications of This History of SAme-Sex MarRiage}

The historical evidence strongly confirms the social constructionist hypotheses about marriage. It cannot be seriously disputed that niarriage is an mstitution that is constructed, not discovered, by societies. The social construction of marriage in any given society is fluid and mobile, and nost societies we know anything about-including the West-have recognized same-sex unions, usually including same-sex marriages, at various ponits in their history.

This Part explores the imphications of social constructionisn for the same-sex niarriage debate. The first implication is that the gaylesbian community should think carefully about whether same-sex marriage should be on the gaylegal agenda. If marriage is socially constructed and tied $\mathrm{n} 1$ with other institutions and practices, my history suggests a further niquiry: Does the gay, lesbian, and bisexual community want to participate in this particular institution as constructed today? Pursumg the liberal arguments for same-sex marriage, advocates assert that we ought to liave the same rights, duties, and obligations as other citizens. But social constructionism poses deeper niquiries: Is niarriage itself a subordinating nistitution? Will it contribute to our longterm happiness and well-being? What effects might same-sex marriage have on our community, our movement, and our lives? I adint to substantial ambivalence on all these issues but on the whole beheve that gaylesbian doubts about same-sex marriage are overstated and that liaving the nuarriage option is useful and productive for us.

If the gaylesbian community continues to press for same-sex marriage, social constructionism undermines the traditional essentialist arguments posed against same-sex marriage. For example, my listory can be offered as proof agaimst most definitional arguments: How can the law deny the existence-imdeed the pervasiveness-of same-sex marriage as a hunian institution when history is replete with examples? Moreover, the history of same-sex marriage rebuts some aspects of the moral and pragmatic arguments as well. Morality, like marriage, is socially constructed. Just as there is no essential definition of nuarriage as different-sex, so there is no essential reading of the Bible that is anti-homosexual. For centuries, the Roman Catholic and Greek Ortliodox Cliurches read the Bible in ways that tolerated samesex couples, and that early reading has seen a revival.

Perhaps the niost useful lesson of social constructionisin is strategic. Because anti-honiosexual attitudes are deeply enibedded in 
American culture, they are exceedingly hard to change. Because they also pervade the law, the law is also hard to change, not because of logic but because of experience. African Americans, however, fought a similar battle a generation ago and made progress against similarly ingrained attitudes. The concluding Section of this Article explores the parallels between the case for saine-sex marriage and the case for mixed-race marriage that underlay the Court's constitutional decision in Loving $v$. Virginia.

\section{A. Should Gaylaw Be Seeking Same-Sex Marriage?}

Once marriage is viewed as a constructed institution with a certain history, the inportant issue for us becomes the following question: Why should we expend scarce resources to expand marriage to include us? The arguments in favor of such an effort strike me as compelling: we should have the saine rights and obhgations as other citizens. Particular couples desire to be married, and marriage can serve useful functions for such couples, including protection against unsympathetic blood relatives and a still-hostile society. ${ }^{242}$ Nancy Polikoff's comment makes several weighty arguments against our making such efforts. ${ }^{243}$ I ain sympathetic but unpersuaded.

\section{The Marriage-Is-Rotten Argument}

Marriage is a rotten institution, say many feininist and gaylesbian scholars. ${ }^{244}$ As constructed in the West, narriage involves hierarchies that have systematically subordinated women's personal, econornic and social interests to those of men. The Ozzie-and-Harriet marriage

242 For several of the different arguments, see Mary C. Dunlap, The Lesbian and Gay Marriage Debate: A Microcosm of Our Hopes and Troubles in the Nineties, 1 Law \& Sexuality 63 (1991); Paula L. Ettelbrick, Simce When Is Marriage a Path to Liberation?, reprinted in Lesbian and Gay Marriage, supra note 236, at 20; Ruthann Robson \& S.E. Valentine, Lov(h)ers: Lesbians as Intimate Partners and Lesbian Legal Theory, 63 Temp. L. Rev. 511, 528-40 (1990); see also Nancy D. Polikoff, This Child Does Have Two Mothers: Redefining Parenthood to Meet the Needs of Children in Lesbian-Mother and Other Nontraditional Families, 78 Geo. L.J. 459 (1990) (discussing the question of child-rearing in same-sex relationships).

243 See Nancy D. Polikoff, We Will Get What We Ask For: Why Legalizing Gay and Lesbian Marriage Will Not "Dismantle the Legal Structure of Gender in Every Marriage," 79 Va. L. Rev. 1535 (1993).

244 See Michèle Barrett \& Mary McIntosh, The Anti-Social Family 57-65 (2d ed. 1991); Shulamith Firestone, The Dialectic of Sex: The Case for Ferminist Revolution 141-42 (rev. ed. 1971); Sylvia A. Law, supra note 11, at 197-206; Robson \& Valentine, supra note 242. 
of 1950s bourgeois America-man as breadwinner, woman as housekeeper $^{245}$-cabins women into constraining roles. Moreover, the legal structure of marriage has been the last haven for malignant social practices, including racism (the prohibition of different-race marriages), contempt for the poor (filing fees and other bureaucratic obstacles to marriage and divorce), and abuse of women (the rule that rape could not occur within marriage) and children (the reluctance of the social welfare system to intervene when children are abused by their middle-class parents).

One constructiomist response to the marriage-is-rotten argument is that same-sex marriage would itself change the institution. As Nan Hunter has argued, same-sex marriages cannot recreate the hierarchy (man as breadwinner, woman as housekeeper) to which feminists object in traditional different-sex marriages. ${ }^{246}$ Even if one partner does the breadwinning and the other partner does the housekeeping, same-sex marriage undermines the mvariable linkage of men to the first role and women to the second, ${ }^{247}$ and there is soine evidence that same-sex couples in America are less likely to follow the traditional breadwinner-housekeeper division in any event. ${ }^{248}$

The history of same-sex marriage told im this Article persuades Nancy Polikoff against Hunter's argument, because most of the examples of same-sex marriage in other times and other places seem to replicate gender hierarchies. ${ }^{249}$ Same-sex spouses of Roman and Clinese emperors, boy wives of the Japanese samurai and Azande warriors, female husbands in Africa, and the umions formed by women passing as men strike Polikoff (and me) as not only replicating but aping the subordimation of "wife" to "liusband" in their respective cultures. Even the berdache tradition, the so-called "third sex,"

245 But did Ozzie have a job? You never saw him working, nor did you ever see Harriet keep house. Maybe this show was quietly subversive.

246 See Nan D. Hunter, Marriage, Law, and Gender: A Feminist Inquiry, 1 Law \& Sexuality 9, 17 (1991).

247 See id.; see also Law, supra note 244 , at 206-12 (describing how the gay rights movement has transformed societal notions of gender); Lewis, supra note 11 , at $1785 \mathrm{n} .12$ (asserting that lesbian mothers, in order to prevail in child-custody hearings, are often forced to define themselves as conforming to sexual stereotypes).

248 See The Mendola Report, supra note 237; sources cited supra note 247.

249 See Polikoff, supra note 243, at 1538-40; see also Nitya Duclos, Some Complicating Thoughts on Same-Sex Marriage, 1 Law \& Sexuality 31, 47 (1991) (observing that legal recognition of same-sex marriages "may contribute to the entrenchment of mutually exclusive and immutable categories of sexual orientation"). 
appears to have yielded marriages in which the berdache generally fell into the stylized role of wife (for the male berdache) or husband (for the female berdache). The best examples of same-sex unions that escape stereotyped gender roles appear to be those that were informal relationships and not legally recognized marriages-the sisterhoods formed by the Chinese marriage resistance movement, Boston marriages of the eighteenth and nineteenth centuries, and the spiritual brotherhoods recognized by the early Christian church. Yet those nonstereotypical unions had little or no discernible influence on their surrounding cultures, again contrary to Hunter's thesis.

The main problem with Hunter's thesis is that it views cultural institutions too simply. Gender roles and attitudes toward women are deeply embedded in a society such as ours, and merely introducing a new institution (saine-sex marriage) will not necessarily change those roles and attitudes, even in the longer term; indeed, as history shows, the old attitudes might absorb the new institution. But this problein also afflicts Polikoff's objection. Polikoff coines perilously close to essentializing marriage as an inherently regressive institution, for in doing so she rephicates the imistake made by the judges and legislators who essentialize marriage as different-sex. That Western marriages have traditionally been the social instrument by which women have been subordinated does not mean that inarriage "causes" that subordination. Women's subordination may be more deeply related to social attitudes about gender differences than to the formal construct of inarriage per se. If that is true, same-sex marriage does not buy into a rotten institution; it only buys into an institution that is changing, as women's roles and status are changing in our society.

\section{The Anti-Assimilationist Argument}

A second argument against pursuing same-sex marriage is that attaining that goal might well declaw gaylesbian radicalism. ${ }^{250}$ To the extent that gaylaw sees itself as a movement to destabilize traditional legal and cultural norms, adopting same-sex marriage as a goal may sound a distinct retreat, expending valuable efforts to achieve a relatively conservative goal whose attainment would tend to "doinesti-

250 See Duclos, supra note 249, at 47; Ettelbrick, supra note 242, at 26; see Polikoff, supra note 243 , at $1541,1546,1549-50$. 
cate" the gay rights movement. ${ }^{251}$ Indeed, it is argued, the process of seeking legally-recognized same-sex marriage involves compromising gaylesbian radicalism, because advocates will invariably find themselves pressured to put forward as plaintiffs or as witnesses at legislative hearings gay and lesbian couples who most resemble Ozzie and Harriet. ${ }^{252}$ Moreover, it is feared that the process of compromise and assimilation would only worsen if we win, as we will have created a giant funnel channeling gay, lesbian, and bisexual energies froin activism to hoinemaking. Just as our radicalism was suppressed by the tyranny of the closet before Stonewall, so it might again be suppressed by a tyranny of the kitchen and garden once saine-sex marriage is legalized.

This is an interesting critique of sane-sex marriage as an aspiration for the gaylesbian rights inovement. The objection romanticizes the moveinent, however, which is not nearly so radical as Polikoff and others envision it. My history of same-sex inarriage offers equivocal support, at best, for the anti-assimilationist position. On the one hand, Ifeyinwa Olinke, We'wha, and the Ladies of Llangdollen were not revolutionary figures, but I doubt they would have been any more radical had they not been able to form lasting ties with their saine-sex mates. On the other hand, saine-sex inarriages have included more than their share of gender rebels-the Pharaoh Ikhnaton, the mythic Gilgamesh, various Roinan emperors, women passing as men throughout history, the protagonists in the stories of $\mathrm{Li} \mathrm{Yu}$, hijras in India, Harlem lesbians in the 1920s, and the marriage resisters of inodern China. Most importantly, marriage might be a refuge for visionaries. Sergius and Bacchus were for their time radicals, because they were Christians. Their relationship supported their Christian activisin, and it was only through the love of Bacchus that Sergius was able to keep faith. To the extent that marriage creates a legal refuge from those who would persecute bisexuals, lesbians, and gay men today, it may be a useful haven for the coinmitted gayradical.

251 Cf. Louis M. Seidman, Brown and Miranda, 80 Cal. L. Rev. 673 (1992) (describing a sense of ambivalence toward Brown and its paradoxical effects on African Americans' struggle for rights).

252 Ozzie and Harriet have always struck me as a rather androgynous couple anyway. If you put Ozzie in a dress, he would be hard to distinguish from Harriet; the reverse is true if you put Harriet in a suit. Note, too, the open androgyny of their two grandsons. 
Social constructionisin raises other interesting questions about the anti-assimilationist arguinent. We are gender rebels because that role has been thrust upon us by oppressive dividing practices, including legal discriminations like the exclusion from marriage. If those dividing practices were to collapse, we might tend to nield back nito society's mainstreain, which does not inevitably strike ne as baleful. To a certain extent, the anti-assimilationist argument is fueled by the anger of the baby boomers, who grew up in an anti-homosexual environment and have fought the hard battles against a coinpulsory heterosexuality whose hallmark is the wedding photo. For that generation (mine and Polikoff's), our difference is essential, a factor that was perhaps necessary to get us organized for the hard, confrontational battles that were fought. This inay be ni the process of changing. The next generation has grown up in an environment where homosexuality is not so strange, and they may be correspondingly less enraged than my generation has been. While many formal and operational discriminations remain, the gaylegal agenda should probably not assuine that gay separatisnı or a lesbian nation is the wave of the future.

Yet that does not mean that gaylesbian culture will altogether cease to be distinctive. One feature of our experience has been an eniphasis on "families we choose" (anthropologist Kath Weston's felicitous phrase) rather than marriage as a way of thinking about our relationships. ${ }^{253}$ Weston's conception of "families we choose" derives from the "coning out" experience, an intense and often difficult time for lesbians and gay men because it places at risk our preexisting blood or family relationships. Mothers, fathers, brothers, sisters, or spouses may reject a previously beloved relative once they are told of her or his sexual orientation. Thus, the emotional support needed to survive coming out derives from "families we choose" and those "who choose us"-supportive relatives and friends. Choice and its acceptance from a variety of sources replaces blood and legal duties as the chief ties im the lives of gay men and lesbians, and this has affected gay and lesbian approaclies to relationships and unions. Our relationships

253 See Weston, supra note 39 (suggesting a conceptual framework linking the "coming out" experience, the formation of lasting gay and lesbian relationships, and the institution of marriage). 
tend to include inore people-close friends and the community as well as the two partners-and to be more free-floating.

Our emphasis on families we choose fuels the gaylegal interest in domestic partnership (which is easier to enter and leave and which requires fewer duties and obligations than marriage) as a better way of protecting many of our relationships than same-sex inarriage. Does the preference of many for domestic partnerships then obviate the need for same-sex marriage rights? I think not. To the extent that coming out to one's family is less traumatic today than it has been in the past, Weston's phenomenon may not be as apphicable to the next generation as it has been to mine. And, in any event, I believe that inarriage is an option that ought to be available to us when we choose our family structure. The inam shared value distinguishing inarriage froin informal relationships or doinestic partnerships is commitment. Although inarriage is not the only way commitment can be deinonstrated in a relationship, the rights and duties attendant upon marriage are the clearest signs of commitınent our society las. Among its many functions is inarriage's role as a social insurance policy. Especially in the shadow of the AIDS epidemic, there is value in an institution that entails such formal and legally binding commitments between the partners.

\section{The New Insiders Argument}

The anti-assimilationist argument folds into a slightly different argument: once inarriage becomes an option for lesbian and gay couples, there will be a selective assimilation, in which a new group of cultural insiders will peel off, leaving the remaimder as permanent outsiders. ${ }^{254}$ Under current law, all same-sex couples are legal outsiders, our relationships invalid and unrecognized. If same-sex marriages became legally authorized, inany lesbian and gay couples would take advantage of the new opportunity to gain some degree of immediate cultural respectability. Over time, these married couples might become insiders, their previously illicit sexuality suddenly sanctioned under the bubble of inarriage. The rest of the gay, lesbian, and bisexual cominunity would remain outsiders.

254 See Ettelbrick, supra note 242, at 23-24; Robson \& Valentine, supra note 242, at 538 (citing Ettelbrick and other commentators). 
Not only would creating a new set of insiders split the lesbian, gay, and bisexual community, but critics believe that it similarly would divide it along familiar gender, race, and class lines. Affluent white male couples are particularly likely to exercise the option to marry because they have the inost to gain, according to some critics. In addition to claiming a lion's share of tangible employer-subsidized spousal benefits, gay couples are also more likely to benefit in terms of social acceptability, signaling to the outside world that they are not "promiscuous homosexuals." In contrast, critics fear that lesbian couples, possibly, and less affluent couples, certainly, would be less likely to exercise the right to inarry, in part because it would yield thein a much smaller economic payoff. ${ }^{255}$ In this way, legally recognizing same-sex marriage could exacerbate already existing tensions within the gay, lesbian and bisexual community.

I am underwhelmed by this argument. Just as I ain dubious that recognition of same-sex marriages would immediately change the institution of inarriage, I am equally dubious that such recognition would legitimate same-sex couples in the eyes of homophobic neiglbors. The hostile neighbor is more likely to change his opinion on tlie basis of actually knowing people who are openly gay or lesbian, and to the extent that same-sex marriage might embolden such couples to be open, then the institution might help all gay men, lesbians, and bisexuals. Moreover, there is no evidence-such as polls, surveys, or theoretical models-suggesting that the marriage option would be disproportionately exercised by rich gay men than by men and women of color, lesbians, or less affuent bisexuals and homosexuals. Lesbians are often the plaintiffs in same-sex marriage lawsuits, and the overwhelming majority of same-sex couples who have actually obtained marriage licenses in the United States have been women, including women passing as men and lesbians of color. ${ }^{256}$

The legitiniate concern of the new insiders argument is that prejudice is multilayered and synergistic in America. Being a woman, a person of color, and a lesbian triggers more liurtful prejudices than just being a gay man. But the availability or nonavailabihty of samesex marriage does not affect that reality. The gay man on average is

255 If one has no job, or has a lower paying blue- or pink-collar job, there are few if any employer-subsidized spousal benefits. Also, there are even fewer ways that greater sexual respectability would advance these types of careers.

256 See sources cited supra note 231 . 
still in a better position, whether he can get married or not. The gay man is less likely to commit himself to gender and race discrimination issues than is the lesbian or the person of color, again whether or not he can get married. The gay man is already more likely to be an insider. Allowing him to marry another man will not change that.

On the whole, I beheve that gaylaw should seek legal recognition of our same-sex relationships on the saine terms that the state provides for different-sex couples. Those terms should include not just marriage, which is the more attractive option for inany same-sex as well as different-sex couples, but also domestic partnership, which is the most attractive option for many different-sex as well as same-sex couples.

\section{B. The Illegitimacy of Traditional Legal Arguments Against Same-Sex Marriage}

If same-sex marriage still ought to be a plank in the gaylegal platform, there remains the problem of persuading straight society to acquiesce in it. Recall the three traditional arguments against sainesex inarriage, either as a matter of statutory right or constitutional mandate: same-sex inarriage (1) is inconsistent with the nature, history, and/or essence of inarriage, (2) is contrary to community values and traditional inoral teachings, and (3) would be disruptive to settled expectations. My history of same-sex marriage helps us to evaluate these arguments. My blunt assessments: The definitional argument is a he. The moral teachings argument is hypocrisy. The pragniatisn argument is more quaint than cogent.

\section{The Definition of Marriage Argument}

Social constructionism's central theme-that inarriage, like other cultural institutions, is a social and not a natural creation-is at war with the definitional argument. ${ }^{257}$ Even my fragmentary history refutes any argument positing that niarriage, froin Adanı and Eve onward, has been different-sex. In fact and in history, saine-sex unions have been legally and culturally recognized as nuarriages anong the Hittites (possibly), in ancient Greece and Ron1e, in Native

257 Cf. Nan D. Hunter, supra note 246 (demonstrating the incoherence of the view that legally created marriages must involve different-sex couples owing to some metaphysical nature of marriage). 
American cultures, all over Africa and Asia, and even in the medieval and modern West.

My history of same-sex umions also undermines various strategies essentializing marriage around concepts such as procreation and gender. Procreation has occurred throughout history without the benefit of marriage, and there are many other social roles that marriage has traditionally played at one time or another around the world, including sustaining economic divisions of labor (Native American berdache marriages and various warrior marriages in Africa and Tokugawa Japan), kinship ties and coahtions (Melanesian ritualized homosexuality), and affectional bonds and mutual emotional support (early Christian enfraternization rituals and more recent Boston marriages). All of these aims have been served by marriage im the West, and marriage's strength as an institution has been its ability to serve many different needs and to evolve and adapt over time. There is no historical reason why Western marriage cannot adapt to include same-sex couples. Not only is procreation not a competent category around which to regulate marriage, but, even if it were, same-sex couples could still justify their own desire to marry. Recall that the precise reason for woman marriage in African societies was to procure heirs for wealthy women who could not bear children theinselves.

Neither does gender prove to be a natural organizing category for definimg marriage, because gender (like marriage) is socially constructed. $^{258}$ No natural reason holds that one's gender must be equivalent to one's biological sex, as the extraordinary history of cross dressing and passing reveals. ${ }^{259}$ Nor is there any reason to conceptualize just two genders; the berdache tradition enduring in hundreds of cultures worldwide suggests that there may be third and fourtl genders beyond male and female, and that a multiphicity of genders enriches a society. Thus, we should not be surprised that even when

258 This is an important theme that has already been developed in feminist scholarship. For a variety of views, see Judith Butler, Gender Trouble: Feminism and the Subversion of Identity (1990); Anne Fausto-Sterling, Myths of Gender: Biological Theories About Women and Men (1985); Luce Irigaray, This Sex Which Is Not One (Catherine Porter trans., 1985); Nature, Culture and Gender (Carol P. MacCorınack \& Marilyn Strathern eds., 1980).

259 What is so remarkable about the history of cross dressing (exhaustively assenibled in Bullough \& Bullough, supra note 181) is that it was so easy to get away with, because clothing and behavior are more rehable indicators of gender than genitalia are. That thousands of women have been able to pass as men in the close confines of the armed forces, see Wheelwright, supra note 221 , is reniarkable evidence of this. 
cultures have defined marriage as the wedding of a "husband" and a "wife," they have nonetheless recognized as marriages relationships involving "boy wives" (as in classical Crete and the East African Nuer), "fernale husbands" (various African cultures), and berdache "[inale] wives" and "[feinale] husbands" (pervasively in Native American tribes and in many Asian societies). Simply put, husband and wife, like male and female, are constructed categories that need not correspond to biological categories. ${ }^{260}$

Such evidence requires opponents of same-sex marriage either to abandon their essence-of-marriage argument or to formulate it inore narrowly. Perhaps the inost that can be said is that, in the history of the Umited States, marriage has always been restricted to different-sex partners. But this argument is not true, either. Native American cultures in the Umited States have continued to recognize same-sex berdache marriages. We'wha and his husband were both American citizens. Moreover, passing woinen, such as Nicholai de Rayan, have frequently married other women in this country, and hundreds of same-sex couples have similarly obtained marriage hicenses from the state, a fact brought to mind by the series of lesbian marriages in Harlem during the 1920s. To my knowledge, none of the same-sex inarriages described im iny survey was ever nullified by the state after being exposed to public attention. Finally, it has been shown that countless gay and lesbian couples have been married in rehgious ceremomes since Stonewall; thousands, for example, were inarried in a mass ceremony on the National Mall during the 1987 March on Washington.

Opponents are then left with only one definitional argument, that no official act of legislation or high court decision has ever sanctioned a same-sex inarriage occurring in the United States. But this is a circular argument in a constitutional case, where the legitimacy of a state's practice is questioned. Is it legitunate for the state to prohibit one class of people from getting married? To say that the state will not give marriage hicenses to same-sex couples because they by "defimition" cannot be married, and then to support that definition by reference to the state's traditional refusal, is not only viciously circular but dissolves the line separating law from fiat.

260 Biological categories are themselves much less binary than the West has traditionally assumed. See supra notes $217-27$ and accompanying text. 
This is precisely the point of constitutional challenges to traditional state laws excluding same-sex marriage: to give officialdom a chance to re-examine a received tradition. Such a rethinking ought to be impelled by the history of same-sex marriage. A similar reassessment is precisely what occurred when the cominunity of social anthropologists came to notice African woman marriages: the discovery impelled them to reconsider how they traditionally defined the "essential" features of marriage. ${ }^{261}$

One official publication, Notes and Queries, defined marriage in 1951 as "a uinon between a man and a woman such that children born to the woman are the recognized legitimate offspring of both partners."262 This definition was a cultural stateinent as inuch as a professional yardstick, and anthropologists familiar with African same-sex marriage traditions in particular seized upon the definition and discredited it. Accordingly, Edinund Leach, a noted social anthropologist, suggested that marriage be defined more loosely as a bundle of rights that society associates with imtimate relationships. ${ }^{263}$ Some anthropologists objected, arguing that such a definition was too open-ended, and Kathleen Gough proposed to define marriage as "a relationship established between a woman and one or more other persons, which provides that a child born to the woman under circuinstances not prohibited by the rnles of the relationship, is accorded full birth-status rights."264

Leach responded that this definition was too restrictive in light of male-male marriages also documented in Africa; he asserted that "all universal definitions of 1narriage are vain,"265 arguing that marriage could only be defined as one or more of the following: (1) the rights and duties inhering in spousedom, (2) the personal relationship between people considered spouses, and/or (3) relationships and alli-

261 For accounts of the debate, see Alan Barnard \& Anthony Good, Research Practices in the Study of Kinship 89-91 (1984); Edmund R. Leach, Social Anthropology 176-203 (1982); 10 Int'l Encyclopedia Soc. Sci. 8-18 (1968); E. Kathleen Gough, The Nayars and the Definition of Marriage, 89 J. Royal Anthropological Inst. 23, 23-24, 32-33 (1959).

262 Royal Anthropological Inst., Notes and Queries on Anthropology 110 (6th ed. 1951).

263 See Edmund R. Leach, Polyandry, Inheritance and the Definition of Marriage, 53 Man 182,183 (1955).

264 Gough, supra note 261 , at 32.

265 Edmund R. Leach, Rethinking Anthropology 105 (1961). 
ances created or cemented by espousal. ${ }^{266}$ Eileen Jensen Krige, author of the earhest work to focus on female husbands, maintained that "[m]arriage can take widely different forms, even sometimes, within the saine society, each involving different categories of rights and duties" and "may be entered upon by people of the same sex."267 The Krige-Leach approach to marriage is now the more accepted among anthropologists, and there seems to be no great reason for lawyers not to follow it as well. Iromically, by treatimg marriage as creating rights, duties, and relationships that relate to demonstrated social functions, this definition seems more lawyerly than the metaphysical procreation-based description found in legal sources.

\section{The Moral Tradition Argument}

Social constructionisni and the history of same-sex niarriage discussed above suggest difficulties with delegitimizing such marriages on moral grounds, especially those invoking the Judeo-Christian tradition. ${ }^{268}$ To begin with, it must be recoginzed that "tradition" is itself a construction and therefore an arena for contest. More importantly, argunients based upon a univocal Christian tradition against same-sex marriages are undermined by history. Roman Catholic and Greek Orthodox Churches performed same-sex enfraternization rituals for centuries, glorified the same-sex intimacy of Sergius and Bacchus, and openly publisled same-sex union liturgies in their official collections. Though controversial, Boswell's claim that these cliurclies also performed same-sex marriage ceremonies is supported by some imdependent historical evidence, such as Montaigne's account of such a marriage within the Vatican itself.

The modern Roman Cathohic Church and niany Protestant denommations remam adamant in tlieir belief that marriage riglits and

266 Leach, supra note 261, at 182-83; accord Barnard \& Good, supra note 261, at 89-91; Rodney Needham, Remarks on the Analysis of Kinship and Marriage, in Rethinking Kinship and Marriage 5-8 (Rodney Needham ed., 1971).

267 Krige, supra note 148 , at 34 .

268 These problems coexist alongside the obvious ones involving the American practice of separating church and state. Even during its most clerically inclined periods as a "Christian Nation," the United States has never considered itself bound by bibical marriage practices. For example, though permitted by all American jurisdictions, divorce is contrary to biblical teaching. In contrast, polygamy-prohibited in all American jurisdictions-was permitted in the teachings of the Old Testament. In any event, efforts to engraft Judeo-Christian ideals onto state regulation would run afoul of the Establishment Clause. 
duties can only be enjoyed by a different-sex couple, but their own position is susceptible to social constructionist analysis. Recall that the Western Church's hardened attitude against saine-sex nitimacy caine only after the nation- and city-states emerging in the late Middle Ages began to target and suppress nonconforming conduct. In my view, the Church was induced into adopting its extreniely intolerant stance, not by any careful examination of Scripture or Church tradition, but as a result of coercion enianating froin society and the state that pressured the Church into cooperating with the anti-Semitic pogronis, the antifeniale witch hunts, and the anti-invert persecutions of the late Middle Ages and the early modern era. Conversely, because the secular reasons justifying society's earlier hysteria have been discredited or shown to be obsolete, this traditional intolerance towards saine-sex couples is now strongly contested within the JudeoChristian faith. Religious leaders accepting saine-sex inarriage are a grownig nuinority. Salne-sex marriages have been performed in virtually all of the inajor Judeo-Christian rehgious denominations and have been specifically sanctioned by many of then1. ${ }^{269}$

The plaintiffs in the Dean case, seeking recognition of sanie-sex marriages in the District of Columbia, sought out the opinions of local rehigious leaders on the issue of sanctioning saine-sex inarriage. ${ }^{270}$ Without asserting that ours was a representative sample of religious leaders, I find the responses to be significant in several respects. First, the priests, ministers, rabbis, and lay leaders who responded struggled with this issue from within the Judeo-Christian tradition and concluded that same-sex marriages are consistent with its foundations. Some, such as the District's congregation of Synagogue Bet Mishpachah, beheve that, although inuch of the Scripture $^{271}$ argues against same-sex niarriage, those admonitions-such as the ones in Leviticus-must be reinterpreted in light of modern understandings. ${ }^{272}$ Others, such as Reverend John Mack of the

269 See Lesbian and Gay Marriage, supra note 236, at 5 (noting that same-sex marriages are allowed in Reformed Jewish, Unitarian Universalist, Episcopalian, Lutheran, Presbyterian, and Methodist congregations, among others).

270 The responses were collected and filed as Appendices 12-22 to the Memorandum on the History of Same-Sex Marriage that I drafted for plamtiffs in Dean v. District of Columbia, No. 90-13892 (D.C. Super. Ct., filed Sept. 4, 1991) [hereinafter Appendices].

271 Recall chapter 18 of Leviticus. See text accompanying notes 51-52.

272 See Letter front Michael D. Garbus, Vice President, Religious Affairs, Bet Mishpachah, to Judge Shellie Bowers, D.C. Superior Court (Aug. 21, 1991) (on file with the Virginia Law 
United Congregational Church of Christ, find the scriptural tradition, especially its eniphasis on love for one's fellow humans, to be generally supportive of church sanction for same-sex marriage. ${ }^{273}$ Reverend William Carey of the fundamentalist Pentecostal Church, who has studied the Bible im its original languages, concludes that the antihoniosexual gloss placed on some passages when translated into Enghish is not faithful to the original text. Recalling that the prophet Damiel and the Babylonian eunuch Ashpenaz were jomed im what he considers a same-sex marriage-specific biblical evidence of favored same-sex unions-Carey argues that same-sex inarriages are faithful to the biblical concepts of commitinent and love. ${ }^{274}$

Interestnigly, clerical sympathy for same-sex inarriage often arises out of denominations that have criticized same-sex intimacy the inost severely. Reverend Carey, a Protestant fundamentalist, is an example. Strikingly, same-sex marriages are once again being performed by ordained priests representing the Roman Cathohc Church. One such priest, Father James Mallon of Philadelphia, views the Church's thinking concerning inatrimony since Vatican II as retreating froln

Review Association) (App. 16): "Jewish tradition has evolved over the centuries and millennia to meet our people's changing needs and circumstances." The letter reports that Jewish congregations around the country have been performing same-sex marriages "over the last two decades." Id.; see also Rabbi Yoel H. Kahn, The Kedushah of Homosexual Relationships, Address at the Central Conference of American Rabbis (May 26, 1989) (on file with the Virginia Law Review Association) (arguing from the Torah and first principles of Judaism that intimacy in God's shadow and not procreation is the essence of marriage (kedushah); that God creates nothing in vaim and does not despise gay, lesbian, and bisexual disciples; and that the Reformed tradition cannot in conscience treat homosexual couples differently from heterosexual couples); Lewis J. Eron, Homosexuality and Judaism, in Homosexuality and World Religions 103 (Arlene Swidler ed. 1993) (discussing the traditional Jewish view of homosexuality as "willfull indulgence" and noting that many Jews today are seeking new ways to include homosexuals).

${ }^{273}$ See Letter from Rev. John H. Mack, Minister, First Congregational United Church of Christ, to Judge Shellie Bowers, D.C. Superior Court (July 31, 1991) (App. 13) (on file with the Virginia Law Review Association):

In my opinion, it is extremely easy to interpret the profound teachings of our religious scripture to apply to same-sex relationships. It is extremely difficult to find clear condemnation of them within the religious literature. And the systemic persecution of those who find romantic love with a person of the same sex violates virtually every Id. major law and teaching of both Judaism and Christianity.

274 See Letter from Rev. William H. Carey, Pastor, Lighthouse Apostolic Church, to Judge Shellie Bowers, D.C. Superior Court (Aug. 1, 1991) (App. 19) (on file with the Virginia Law Review Association). Reverend Carey also relies on Boswell's widely-reported research that the Catholic Church "routinely performed wedding ceremonies for homosexual couples." Id. 
the Church's long-standing demand that marriage be linked to procreation and endorsing marriage as a loving covenant between two people, an evolution that Father Mallon believes validates same-sex unions, which he has performed. ${ }^{275}$ Father John McNeill, an acclaimed Cathohc scliolar, justifies his favorable view of same-sex niarriage by invoking the Christian Church's early hiturgies sanctioning same-sex niarriage, and he hiniself celebrates conımitnient services for same-sex couples. ${ }^{276}$

These Catholic scholars have not been alone im grounding their willingness to consecrate same-sex inarriages on a new understanding of early Cliurch practices. Similarly, the National Capitol Presbytery states in a recent pamphlet addressing the issue:

What was the historical Christian position on heterosexual marriage and blessing of same-sex unions?

John Boswell, Chairman of the History Department of Yale University, will publish research on this question in late 1991. While translating old Vatican manuscripts, Boswell discovered 100 distinct ceremonies used by the church to bless the union of same-sex couples. The same-sex ceremonies were located within the same sections of books containing inarriage cereinomies. Official church ceremonies for sanie-sex couples were used over a period of 1500 years, beginning in the 5th century. ${ }^{277}$

Notably, a similar process of reinterpreting same-sex traditions is taking place within sonie factions of the traditionally anti-honısexual Mormon Cliurch as well. ${ }^{278}$

275 See Letter from Father James P. Mallon, Dignity, to Judge Shellie Bowers, D.C. Superior Court (July 29, 1991) (App. 14) (on file with the Virginia Law Review Association) (attaching "Dignity Philadelphia: Guidelines for the Rite of Union/Covenant Liturgy").

276 "Commitment services have been part of the Church's rituals since the third century. (In fact, scholars have proof that these same-sex rites were the original source of heterosexual marriage rituals when they were first introduced in the thirteenth century.)" Letter from Father John J. McNeil to Judge Shellie Bowers, D.C. Superior Court (undated) (on file with the Virginia Law Review Association) (including a conımitment ritual which he uses). See generally Denise Carmody \& John Carmody, Homosexuality and Roman Catholicism, in Homosexuality and World Religions, supra note 272, at 135 (providing the historical background to Ronian Catholic attitudes toward homosexuality and expressing hope that those attitudes are softening).

277 National Capital Presbytery, Questions Before the Church on the Issue of Union Cerenonies for Gay and Lesbian Couples (1991).

278 See Antonio A. Feliz, Out of the Bishop's Closet 81-83, 93-94 (2d ed. 1992). The author argnes fron evidence in Mormon archives that Joseph Smith, the founder of Mormonisn1, "sealed" men to men and blessed intimate relationships between then. Feliz was a closeted 
Second, the letters indicate that these churches and religious leaders are specifically seeking to withdraw rehgious tradition as a justification for the secular persecution of lesbians, gay men, and bisexuals. These leaders see the opportunity to reassess same-sex marriage favorably as one way by which to reinterpret that tradition in hight of estabhished rehgious themes such as loving commitment, equality, and nondiscrimination. Thus, we received a number of letters from various Quaker Meetings that had considered whether to perform Quaker marriage ceremomies for same-sex couples. ${ }^{279}$ The prevailing theme of these letters was that it is unjust to treat loving and committed samesex couples differently from heterosexual couples. ${ }^{280}$ Presbyterian Reverend Carla Gorrell's letter likewise asks "when will our civil and rehgious systems take the lead to overcome unreasoned prejudice, as was necessary in earher movements for African-American and women's rights?"281

Third, these letters suggest that the decision to recognize same-sex marriage should be embraced as a tremendous opportunity for reform and not feared as a difficult and disturbing problem. Methodist Reverend Richard Stetler put it inost eloquently:

Should society allow two men or two women to marry? From my perspective, I behieve an opportunity is here for the court to set a valuable precedent.

... Permit one example which is all too commonplace. A year ago, a colleague of mine watched two people's hives beconie torn apart by our legal system. One was dynig of AIDS while the other-the caregiver-reniamed helpless to make any decisions on his lover's behalf because he was not considered "family." The caregiver struggled with agency after agency all to no avail. Finally, when the partner with AIDS died, his mate stood by while all the funeral

gay bishop in the Mormon Church and had access to the equally closeted archives. After coming out, Feliz was separated from the Mormon Church, and I assume that the Church does not agree with his view of the evidence.

279 See, e.g., Letter from Peggy Monroe, Oversight Committee, University Friends Meeting, to Judge Shellie Bowers, D.C. Superior Court (Aug. 2, 1991) (on file with the Virginia Law Review Association).

280 See, e.g., id. (stating that their church "beheves it is in keeping with the Quaker testimony of equality that loving relationships between two people be acknowledged, accepted, and cared for without distinction to sexual orientation").

281 Letter from Rev. Carla B. Gorrell, Minister, Westminster Presbyterian Church, to Judge Shellie Bowers, D.C. Superior Court (Aug. 5, 1991) (App. 20) (on file with the Virginia Law Review Association). 
arrangements were made by the biological family, arrangements which were against the deceased's desires. The family proceeded to take all of the deceased's belongings. All the caregiver wanted were mementos of their hives together, but the family, hiving out its denial, left him with nothing but memories. ${ }^{282}$

This letter and all the rest are a testament to a social constructionist understanding of religious tradition: like social attitudes, religious beliefs are thenıselves situated in history and are therefore fluid. The fluidity of religious behefs highlights the responsibility of the faithful to interpret thein in ways that are productive and not hurtful. Such an opportunity has been presented in the 1980s and 1990s, and leaders such as Reverend Stetler are reniterpreting their faith in ways that inspire.

\section{The Pragmatism Argument}

The pragmatist can respond that it is all well and good that there is nothing new about same-sex marriage, and that society and religion inay be in the process of reacquamting theinselves with that institution, but same-sex inarriage would still require that the law be changed to permit it. Such a change, the pragmatist reninds, would profoundly upset inany people, who are shocked by the idea of expanding niarriage, and unsettle eniployinent and other arrangeinents that have evolved during a period in which it was assuned that inarriage was himited to heterosexual couples. Pragmatisin thus einphasizes the web-like and interdependent nature of cultural institutions, and argues that because so niany of our cultural foundations and beliefs are interconnected, state-sponsored change can only be incremental if stability and society's faith in its institutions are not to be undermined. In short, let society come to accept same-sex inarriage, and then the law may follow. ${ }^{283}$

At the descriptive level, social constructionism is similar to prag1natism in that both consider all social institutions and attitudes interconnected. At the normative level, however, social constructionism parts coinpany with pragmatism in its evaluation of an institution's

282 Letter from Reverend Richard E. Stetler, Minister, Capitol Hill United Methodist Church, to Judge Shellie Bowers, D.C. Superior Court (August 13, 1991) (on file with the Virginia Law Review Association).

283 This is explicit in Posner, supra note 33, at 313 (endorsing donestic partnership laws but reluctant to adopt same-sex marriage), and implicit in the judicial decisions discussed in Part $\mathrm{I}$. 
legitimacy. This is because social constructionisn considers legal categories to be not only socially created, but typically developed as part of a pattern of scientific classifications and dividing practices having the effect of subordinating certain groups in society. Within this understandinig, a legal definition of niarriage to exclude same-sex couples constitutes a dividing practice by which certain groups in our society exercise power over gay nien, lesbians, and bisexuals. ${ }^{284}$ Justifying such dividing practices is oftentimes normatively difficult. As recently as the 1960s, widely accepted scientific arguments were voiced supporting the niarginalization of "sick honısexuals" froin "normal" society. Yet in the last twenty years those arguments have collapsed like a folding chair, and one exclusion after another has fallen under the determined assault of now-1nobilized lesbians, gay neen, bisexuals, and our allies. ${ }^{285}$ Marital exclusion is the nuam de jure discrimination agamst us that renams at the state level. It is normatively unjustified as a denial of our rights as citizens and ought to fall-on constitutional grounds if necessary.

Social constructionisnı further suggests that praginatisn1, when reasonably exercised, cannot long tolerate dividing practices once they have been "exposed." That is, social dividnig practices and scientific classifications do nrore than subordiniate; oftentimes, they impel the subordinated people to form their own group identity and, at sonie point, to resist being categorized by revealing that no legitimate reason justifies denying then their fundaniental rights on the basis of a particular characteristic. When that happens, as it did for African Americans, for wonien, and now for bisexuals, gay nien, and lesbians, the praginatist needs to end or ameliorate the offending categorization if she wants to head off social turmoil. There is an excellent conserva-

284 See generally Paul Rabinow, Introduction to The Foucault Reader 3, 7-11 (Paul Rabinow ed., 1984) (discussing Foucault's views that human society isolates certain subgroups as a means of dominating them).

285 Most sodomy laws are now either repealed, unenforced, or enforced with some effort to apply the law to both heterosexual and homosexual sodomy. The ability to exclude gay, lesbian and bisexual immigrants under federal iminigration law was essentially voided by the Public Health Service's repudiation of the legislation in 1979 and its formal repeal in 1990. Security clearance discrimination on grounds of sexual orientation greatly diminished in the 1980 s and will probably be formally (but perhaps not functionally) ended during the Clinton Administration. 
tive case to be made for permitting same-sex marriage, ${ }^{286}$ and society must come to recognize that sooner or later.

Of course, pragmatisin can argue for later rather than sooner, preferring incremental change to immediate action. Indeed, those favoring a slow evolution can appeal to my history of same-sex unions for support. Though their ebbing and flowing in different societies was sometimes abrupt-different einperors im ancient China and Roine encouraged very different marital practices at court, for examplemore often they developed gradually, responding to other slow-moving social changes. Yet I would respond to such arguments by appealing to analogy, specifically by examining American society's experience with the abrupt termination of its prohibition of differentrace marriages, an event to which I now turn.

\section{Loving and the Miscegenation Analogy}

Loving $v$. Virginia, ${ }^{287}$ the principal case estabhishing the due process right to marry, also provides the best analogy for gaylaw's view that the practice of excluding lesbian and gay couples from state-sanctioned marriage should be abruptly rather than gradually ended. Social constructiomism provides a different account of Loving than does traditional theory, an account that makes Loving a more favorable analogy for those questioning state laws prohibiting samesex inarriage.

Loving is mainly an equal protection case. The Court's discussion of the "right to marry" is an alternative holding, coming at the end of its opinion and occupying less than a page in the United States Reports. ${ }^{288}$ The primary holding of the Court was that the Virginia antimiscegenation statute was a racial classification and that the state offered "no legitimate purpose independent of invidious racial discrimination which justifies this classification."289 Although the Court's equal protection holding was contrary to the specific expectations of the frainers of the Fourteenth Amendinent, it is analytically robust because it impleinents the central purpose of the Reconstruc-

286 See Andrew Sullivan, Here Comes the Groom: A (Conservative) Case for Gay Marriage, New Republic, Aug. 29, 1989, at 20.

287388 U.S. 1 (1966).

288 See id. at 12.

289 See id. at 7-12. 
tion Amendments, to remove legal disabilities grounded upon race. ${ }^{290}$ But the strength of Loving's equal protection analysis renders vulnerable its doctrinally weaker discussion of the due process right to marry. Although the Supreme Court has expanded Loving's right to marry to other classifications, including prisoners, ${ }^{291}$ the right's mooring im substantive due process inakes it a fickle doctrine, and one that traditional thinking seems unlikely to expand to protect gay and lesbian couples stigmatized by the Court's subsequent decision in Bowers v. Hardwick, which refused to expand the substantive due process right of privacy to protect same-sex intimacy. ${ }^{292}$

Whereas the traditional account of Loving invites one to disaggregate the equal protection and due process stories, the social constructionist account of Loving insists that they are both elements of the saine story. ${ }^{293}$ What was under attack in Loving was an essentialisin about race and inarriage, and Virginia defended its statute precisely along those lines. According to the state, race is a fundamental dividing characteristic created by God:

"Almighty God created the races white, black, yellow, malay and red, and he placed them on separate continents. And but for the interference with his arrangements there would be no cause for such marriages. The fact that he separated the races shows that he did not intend for the races to mix.",294

290 Loving is hard to defend as deriving from the Framers' "original intent" in enacting the Reconstruction Amendments, because when they were adopted the states prohibited differentrace marriages, as Chief Justice Warren's opinion recognized. See id. at 9. Instead, his opimion rested upon the Framers' general purpose, i.e., to remove the legal vestiges of slavery. For more on the issue of original intent, see Alexander M. Bickel, The Original Understanding and the Segregation Decision, 69 Harv. L. Rev. 1 (1955); Anthony E. Cook, The Teniptation and Fall of the Original Understanding, 1990 Duke L.J. 1163.

291 See Turner v. Safley, 482 U.S. 78, $94-99$ (1987).

292478 U.S. 186, 194 (1985) ("[T]o claim that a right to engage in [sodomy] is 'deeply rooted in this Nation's history and tradition' or 'implicit in the concept of ordered liberty' is, at best, facetious.").

293 For the story that follows, see generally Robert J. Sickels, Race, Marriage, and the Law (1972) (summarizing the history of antimiscegenation laws); A. Leon Higginbotham, Jr. \& Barbara K. Kopytoff, Racial Purity and Interracial Sex in the Law of Colonial and Antebellum Virginia, 77 Geo. L.J. 1967 (1989) (discussing the historical development of antimiscegenation statutes and related laws as a means of inaintaining white "racial purity"); Herbert Hovenkamp, Social Science and Segregation Before Brown, 1985 Duke L.J. 624 (arguing that the jurisprudence of race relations in the late mineteenth and early twentieth centuries refleeted the prevailing scientific views about separation of the races).

294 See Loving, 388 U.S. at 3 (quoting the Virginia trial court's opinion upholding the statute). 
Based on this understanding of race, the Virginia Supreine Court held that the state inust have the power

to regulate the marriage relation so that it shall not have a mongrel breed of citizens. We find there no requirement that the State shall not legislate to prevent the obhiteration of racial pride, but must permit the corruption of blood even though it weaken or destroy the quality of its citizenship. ${ }^{295}$

Decisions upholding antimiscegenation statutes in other states einphasized the same religious and "scientific" arguments. ${ }^{296}$ For example, the Georgia Supreine Court upheld its statute in part because "amalgamation of the races is . . . uunatural," yielding offspring who are "generally sickly and effeminate, and . . . inferior in physical developinent and strength, to the full-blood of eitlier race,"297 and in part because

equality [of the races] does not in fact exist, and never can. The God of nature made it otherwise, and no human law can produce it, and no human tribunal can enforce it. There are gradations and classes throughout the universe. From the tallest arch angel in Heaven, down to the ineanest reptile on earth, noral and social inequalities exist, and must continue to exist through all eternity. ${ }^{298}$

The Tennessee Supreme Court empliasized the necessity of sucli laws "[t]o prevent violence and bloodshed which would arise froin such cohabitation, distasteful to our people, and unfit to produce tlie liuinan race in any of the types in which it was created."299

What Loving was rejecting, therefore, was not an abstract claim of state power but an ideology of white supreinacy. ${ }^{300}$ That ideology created a group-consisting inainly of African Americans-and then

295 Naim v. Naim, 87 S.E.2d 749, 756 (Va.) (upholding the same anti-miscegenation statute), vacated, 350 U.S. 891 (1955).

296 It is stated as a well authenticated fact that if the issue of a black man and a white woman, and a white man and a black woman, intermarry, they cannot possibly have any progeny, and such a fact sufficiently justifies those laws which forbid the imtermarriage of blacks and whites....

State v. Jackson, 80 Mo. 175, 179 (1883). See generally Paul A. Lombardo, Miscegenation, Eugenics, and Racism: Historical Footnotes to Loving v. Virginia, 21 U.C. Davis L. Rev. 421 (1988) (explaining how eugenics was used to support the act struck down in Loving).

297 Scott v. Georgia, 39 Ga. 321, 324 (1869).

298 Id. at 326.

299 Lonas v. State, 50 Tenn. 287, 299-300 (1871).

300 See Loving, 388 U.S. at 11. 
sought to isolate that group from mainstream society. Antimiscegenation statutes constituted one dividing practice used by the state to isolate and marginalize black citizens. By invalidating the law, the Court rejected state efforts to create a caste of second-class citizens by excluding them from the right to marry.

The similarity between prohibitions of different-race and saine-sex marriages should now be clear. Virginia and other states relied on precisely the saine definitional (marriage lias never included differentrace couples), morality-based (God ordained this), and praginatic (people would be upset) arguments to prohibit different-race marriages that states now invoke to prohibit same-sex marriages. All of tliese are mice liberal arguments, and they all rest upon ugly social constructions. Just as white supremacy is the ideology that undergirds excluding different-race couples from the institution of marriage, homophobia is the ideology that undergirds excluding same-sex couples from that same institution. Both tenets rest upon hate and fear, seeking to isolate a group of worthy people from full citizenship. Once those repressed by dividing practices such as this one recognize that their isolation is unnecessary as well as hurtful, they resist it. And once they resist, there is hell to pay until the system relents, which it ought to do promptly.

The system can do so based upon Loving. One line of argument, suggested by Sylvia Law and Andrew Koppelinan, ${ }^{301}$ is the following: A prohibition against same-sex marriage is a facial gender classification because the license is demied to a female-female couple simply because of their gender (a female-male couple would be treated differently). ${ }^{302}$ Such a gender classification, like the racial classification in Loving, triggers lieiglitened scrutiny under the Supreme Court's equal protection jurisprudence, thougl gender categories receive "imtermediate" scrutiny, whereas race categories receive "strict" scrutiny. ${ }^{303}$ The state classification cannot survive intermediate scrutimy because its justifications for prohibiting saine-sex marriage rest upon an ideol-

301 See Law, supra note 11, at 230-33; Andrew Koppelman, Note, The Miscegenation Analogy: Sodomy Law as Sex Discrimination, 98 Yale L.J. 145 (1988); see also James Trosino, Note, American Wedding: Same-Sex Marriage and the Miscegenation Analogy, 73 B.U. L. Rev. 93 (1993) (comparing the effort to legalize mixed-race marriage with the ongoing struggle to legalize same-sex marriage).

302 Id. at 149-53.

303 Id. at $154-57$. 
ogy of homophobia and rigid gender stereotypes. ${ }^{304}$ That the state classification may also deny people their due process fundamental right to marry reinforces the need for the Court to imvalidate the classification.

African-American and gaylesbian efforts to imtegrate marriage share a deep similarity, therefore. That is not to say, however, that there are no differences between Loving and the same-sex marriage cases, the primary difference being that Loving followed Brown v. Board of Education, ${ }^{305}$ whereas the recent same-sex marriage cases follow Bowers. Brown, a civil rights triumph that sounded the death knell to the ideology of white supremacy as a matter of state policy, at least as a matter of state policy, foreshadowed Loving. In contrast, Bowers can be read to stand for the triumpli (perhaps temporary) of an ideology of homopliobia as a matter of state policy, leaving samesex marriage advocates stranded until Bowers is overruled. Even if Bowers were overruled and a gaylegal version of Brown adopted by the Court, the argument for recognizing same-sex marriage would still remain incomplete if Loving is any guide. Important to the Loving analysis-and one reason why it took the Court thirteen years after Brown to reacli the issue ${ }^{306}$ - was the Court's observation that state statutes prohibiting different-race umions had, by 1967 , become the exception ratler than the rule. ${ }^{307}$

Notwithstanding these differences, the Loving analogy has been accepted by the Hawañ Supreme Court. In Baehr v. Lewin, ${ }^{308}$ the Court vacated a trial court decision dismissing a constitutional challenge to the state's prohibition of same-sex marriages and remanded the case to allow the state to present a compelling state interest to justify its gendered classification. ${ }^{309}$ However that case is ultimately

304 Id. at $158-62$.

305347 U.S. 483 (1954).

306 The Brown Court had an opportumity to strike down Virginia's law in Naim v. Naim, 350 U.S. 891 (1955) (vacating and remanding the case to the circuit court due to the "inadequacy of the record"), but ducked the issue because of pragmatic fears that any order would be openly disobeyed in the South. See Bernard Schwartz, Super Chief: Earl Warren and His Supreme Court 158-62 (1983).

307 Loving, 388 U.S. at 6 \& n.5 (reporting that in 1967 only 16 states prohibited differentrace marriages, and that between 1952 and 1967, 14 states repealed their prohibitions of different-race inarriages).

308852 P.2d 44 (Haw. 1993).

309 See id. at 67. 
decided, it suggests several lessons for the gaylegal struggle for samesex marriages. One is that the due process right to marry challenge continues to be an uphill battle. All of the justices voting in Baehr rejected the plamtiffs' due process challenge, although four of the five voting justices were open to some kind of equal protection challenge. ${ }^{310}$ From a social constructionist point of view, this makes sense: state prohibitions agamst same-sex marriage are "classifications" designed to hurt a category of citizens who do not warrant it.

A further lesson from the Hawain hitigation may be that constitutional challenges in state courts may be more productive than federal challenges. State courts are not obligated to follow Bowers, and indeed several have struck down their sodomy laws. ${ }^{311}$ Starting from constitutional scratch, the gender discrimination argument based upon Loving is more powerful if the audience is not favorably disposed toward Bowers. Baehr took precisely this approach. ${ }^{312}$

A concurring opinion in Baehr favored a remand to consider whether sexual orientation is a classification that should trigger heightened scrutiny under the Hawaï Constitution. ${ }^{313}$ Some state courts have apphed heightened scrutiny to sexual orientation classifications, ${ }^{314}$ and I consider a sexual orientation discrimination argument a complement to the sex discrimination arguinent Law and Koppelman liave set forth. A gap in the analogy to Loving is that the connection between the discriminatory classification (sex) and the harm (reinforcing gender stereotypes) is abstract and hard to counect

310 See id. at 55-63 (rejecting plaintiffs' due process argument); id. at 63-67 (holding that sex is a suspect class under the Hawaii Constitution). Five judges participated in oral argument on the case: Acting Chief Justice Ronald T.Y. Moon and Justice Steven H. Levinson, regular members of the Court; appeals court Judges James S. Burns and Walter M. Heen, designated to serve in place of two Justices who recused themselves; and retired Justice Yoshimi Hayashi, temporarily assigned to fill a vacancy on the Court. Levinson, Moon, and Burns voted to vacate the trial court opinion; Levinson wrote the plurality opinion, id. at $48-70$, joined by Moon; Burns concurred in the result. Hecn wrote a dissenting opinion, id. at 70-74, which Hayashi would have joined, but his assigument ran out before the opinions were filed. Justice Paula A. Nakayaina later participated in the case, voting with the plurality and thereby making it a majority opinion.

311 Some states had struck down their sodomy laws on privacy grounds before Bowers, see People v. Onofre, 51 N.Y.2d 476 (1980), and at lcast one state has struck down its sodomy law on state privacy grounds after Bowers. See Kentucky v. Wasson, 842 S.W.2d 487 (Ky. 1992).

312 See Baehr, 852 P.2d at 48-70.

313 See id. at $69-70$ (Burns, J., concurring in the result).

314 See Kentucky v. Wasson, 842 S.W.2d 487 (Ky. 1992); Gay Rights Coalition v. Georgetown Univ., 536 A.2d 1 (1987) (en banc). 
with legislative motivations. Judges may find it difficult to understand how denying two gay men the right to marry is driven by an ideology that oppresses straight women.

That is why Sylvia Law's formulation of the argument is particularly important, for she argues that what undergirds the prohibitions against same-sex marriage is an ideology of "heterosexism." 315 The ideology is an essentialism of gender, im whicl women are naturally lieterosexual and naturally desirous of marrying men, which naturally results in their bearing children. By defining marriage as "essentially" and necessarily different-sex, the state is essentializing marriage in a way that reinforces traditional gender roles. Law argues, and I agree, that the Equal Protection Clause's prohibition of unjustified gender discrimination implicates state exclusions of saine-sex couples.

The history of same-sex marriage provides some support for this reading, though the matter is complicated. Ancient cultures (Egypt, Mesopotamia, Greece, and Roine) maintained strict patriarclial lines of authority over women yet also tolerated saine-sex unions ainong men, which fit into the prevailing patriarcliy. More recent experience reveals a connection between intolerance of same-sex unions and suppression of women-witch liunts of inverts as well as spinsters in early modern Europe, the colomial attacks on women's economic opportunities and feinale husbands in Africa, and even recent lesbianbaiting addressed to femmist leaders-and between tolerance of sainesex umions and imcreasing opportumities for women-including berdache unions among Native Americans, woman marriage in Africa, and the marriage resistance movement in China.

Based on this evidence, I would not argue that there is an "inherent" connection between saine-sex marriage and women's equality because recognizing inale-male uinons and even "liarmless" feinale friendships can contribute to gender lierarcliy. But under the particular circunistances of our culture, I would suggest that there is a direct link between tying women to the kitclien and ostracizing sainesex couples from the bedroom.

\section{CONCLUSION: GAYLESBIAN HISTORY AND LAW}

History is one of the ways a dominant group perpetuates its subordination of otler groups. By telling the story of its triumpli as tlougl1

315 See Law, supra note 11, at 232; Lewis, supra note 11. 
it were natural, inevitable, and good, the dominant group can induce the rest of us to accept its domination. When a suppressed group becoines conscious of its unfair subordination, one response is to write its own version of history. This Article is an exercise in such counterhistory, froin a gaylesbian perspective.

Counterhistory is a way for a suppressed community to claim our own identity. By reinterpreting tradition, we are constructing our present situation and inviting the formation of cominunity. By linking our present experiences of intimacy with those of other cultures as well as those of Western culture, we gain a inore profound sense of rootedness-and greater confidence in our defiance of dividing practices that seek to exclude us as God's children. By examining the many different ways hunian culture has constructed saine-sex unions, we can better decide which constructions best serve our purposes.

Mainstream culture and law should also be attentive to counterhistory. When a group like gay men and lesbians recognizes the imjustice of its exclusion and mobilizes against it, the sniart thing for maimstream society to do is accommodate the group. Admittedly, the process of accommodation suppresses the interests of those for whoin the exclusion of some helps constitute their vision of a good society. As to then1, I would say that a niature constitution is one that depends on conimitnent and cooperation, and not exclusion and persecution. Rethink your views in hight of our history, so replete with examples of intimacy and sharing. The greatest value of counterhistory is to suggest ways in which minority practices-like same-sex marriage-have been valuable and productive across timies and cultures. 


\section{APPENDIX}

\section{The Office for the Establishment of Spiritual Brotherhood}

The Office presented below has ancient roots in ecclesiastical and secular law. It is found in many codices and we have taken it from the best ones.

The priest begins with the Blessing, the "All Holy Trinity," the "Our Father . . . For Thine is the Kingdom." Then he says with measured pace, "O Lord, save your people and bless your heritage." Those who are to be joined in fraternal unity stand, their hands on the Holy Gospel, while holding highted candles. The priest continues:

Glory ... . O Holy Apostles ... .

And now ... O Lord at the intercession ...

And then the Great Litany:

Let us pray to the Lord in peace.

For the peace from above...

For this holy house...

For the Archbishop ...

For the servants of God who have come to be blessed and for their love in Christ, let us pray to the Lord.

That there be given them the knowledge of Apostohic friendship, let us pray to the Lord.

That it be theirs to be worthy to the glory im the Precious Cross, let us pray to the Lord.

That they and we be dehivered from all affliction, anger, and necessity ...

Help us, save us, have pity for us, O Most Holy, Most Pure.

The exclamation: For to You belong all Glory ...

Let us pray to the Lord:

O Lord, our God, You will the salvation of us all; as You have commanded us to love one another and to forgive one another our offenses, do now with kindness, $O$ Lord, grant to Your servants jomed to each other with a spiritual love, who have come to Your Holy Temple to receive the Blessing, a sound faith and a sincere love. And as You gave peace to your Holy Disciples, so also give all things necessary for salvation and bestow hife everlasting. For You are a merciful and gracious God and to You we ascribe Glory. To the Father and to the Son and to the Holy Spirit.

Let us pray to the Lord:

O Lord God alınighty, Creator of Heaven and Earth, You made man in Your Image and Likeness. You joined your Holy Martyrs 
Sergius and Bacchus to each other as brothers, not by nature, but by faith and the bond of the Holy Spirit. O Lord, having sent that Your Same Holy Spirit upon Your servants who have come by Grace to this Holy Temple to receive a blessing, grant thein a firm faith and a love without dissimulation, without mistrust or offense to turn to one another, for Yours is the Kingdom and the Power and the Glory of the Father and of the Holy Spirit, now and forever and through the ages.

A table has been prepared in the middle of the Church, and the Holy Gospel is set upon it. The couple kiss each other while the priest sings:

By the bond of love bound to one another, the Apostles consecrating themselves to Christ, the Lord of All, went forth to announce peace with beautiful feet.

The Priest:

May God have mercy on us.... and the rest.

Source: Ritualae Graecorum Complectens Ritus et Ordines Divinae Liturgiae 707 (R.P. Jacobi Goar ed. \& trans., reprinted in 1960). This is my translation from the Latin, checked against that of The Most Reverend Jonah, Bishop of Berkeley. Father Alexei Michalenko, the Chaplain of the Georgetown University Law Center, originally brought this nuaterial to my attention. 
HeinOnline -- 79 Va. L. Rev. 15141993 